九州大学学術情報リポジトリ

Kyushu University Institutional Repository

\title{
THE FAMILY CURCULIONIDAE OF JAPAN. IV. SUBFAMILY RHYNCHAENINAE
}

Morimoto, Katsura

Entomological Laboratory, Faculty of Agriculture, Kyushu University

https://doi.org/10.5109/2490

出版情報: ESAKIA. 22，pp.5-76，1984-11-20. Entomological Laboratory，Faculty of Agriculture， Kyushu University

バージョン :

権利関係 : 


\title{
THE FAMILY CURCULIONIDAE OF JAPAN. IV. SUBFAMILY RHYNCHAENINAE ${ }^{1,2)}$
}

\author{
Katsura Morimoto \\ Entomological Laboratory, Faculty of Agriculture, \\ Kyushu University, Fukuoka 812, Japan
}

\begin{abstract}
A revision of the Curculionid subfamily Rhynchaeninae of Japan is presented including the review of the subgeneric classification of the palaearctic Rhynchaenus. Six genera and 45 species are recognized. One subgenus of Rhynchaenus and 14 species are described as new. New taxa and synonymies treated in this paper are as follows :

Ixalma memnonia sp. nov.

Rhamphus pulicarius (Herbst, 1795)

= Rhamphun pullus Hustache, 1920. syn. nov.

Rhynchaenus (Nomizo) kamiyai subg. et sp. nov.

R hynchaenus (Isochnus) sorbi sp. nov.

Rhynchaenus (Alyctus) cylindricus sp. nov.

Rhynchaenus (Alyctus) kimotoi sp. nov.

Rhynchaenus (Alyctus) aterrimus (Roelofs, 1874)

= Rhynchaenus mumon (Kôno, 1930). syn. nov.

Rhynchaenus (O rchestes) miyatakei sp. nov.

R hynchaenus (0 rchestes) lateritius sp. nov.

R hynchaenus (O rchestes) harunire sp. nov.

Rhynchaenus (O rchestes) nitens sp. nov.

Rhynchaenus (Orchestes) truncatipennis sp. nov.

Rhynchaenus (O rchestes) villosus $\mathrm{sp}$. nov.

Rhynchaenus (O rchestes) variegatus (Roelofs, 1874)

= $\mathbf{R}$ hynchaenus spinosus (Hustache, 1920). syn. nov.

Rhynchaenus (O rchestes) hidakai sp. nov.

Rhynchaenus (0 rchestes) heritierae sp. nov.

Rhynchaenus (O rchestes) trifasciatus sp. nov.
\end{abstract}

Weevils of the subfamily Rhynchaeninae are characteristic in their swollen hind femora and saltatorial habit in the typical species, but the exact definition to this subfamily is still in chaos at present.

1) Contribution from the Entomological Laboratory, Faculty of Agriculture, Kyushu University, Fukuoka (Ser. 3, No. 155).

2) This work was supported in part by Grant-in-Aid for Scientific Research No. 57480043 from the Ministry of Education, Science and Culture. 
In Coleopterorum Catalogus, Klima (1935) enumerated eight genera in this subfamily, and three genera have been described and one genus was transferred to it after that. Thus, 12 genera are now included in this subfamily on record. Copidorrhinus Marshall, 1948, in the Anthonominae is probably a genus of this subfamily near Orches to ides.

The tribe Dinorhopalini including Ixalma Pascoe and Dinorhopala Pascoe have been classified in the Tachygoninae, Eugnominae, Anthonominae or in the Cossoninae. Their taxonomic position is problematical for me, because of the lack of adequate informations on the related subfamilies. In this paper I treat the tribe Dinorhopalini in the subfamily Rhynchaeninae followed after my previous works (1962, 1964).

For the present study, about 2300 specimens of Japanese and 150 specimens of European and Oriental species of this subfamily in the collection of the Kyushu University have been examined. The type materials described by Kôno, Hustache, Roelofs, and Marshall in the following collections were also examined : Entomological Institute, Faculty of Agriculture, Hokkaido University, Sapporo ; Muséum National d' Histoire Naturelle, Paris ; and British Museum (Natural History), London.

I wish to express my sincere gratitude to Prof. Y. Hirashima, of Kyushu University, for the helpful suggestions and encouragement in the course of the present study. I am indebted to Dr. 0. Tadauchi, of Kyushu University, for the cluster analyses by computer.

I heartly thanks to the following entomologists for their kind help on materials. Dr. K. Baba, Prof. M. Chûjô, Mr. H. Ichihashi, Mr. H. Irie, Prof. S. Kimoto, Prof. K. Kojima, Dr. Y. Kurosawa, Mr. H. Makihara, Mr. T. Matoba, Mr. T. Mikage, Mr. S. Miyakawa, Mr. Y. Miyake, Prof. S. Miyamoto, Mr. Y. Miyatake, Prof. Y. Murakami, Prof. H. Sasaji, Prof. T. Shirôzu and Dr. S. Uéno.

\section{Subfamily RHYNCHAENINAE}

Rhynchaeninae sensu Morimoto, 1962, J. Fac. Agr., Kyushu Univ., 12 : 38, 42. -Morimoto, 1964, Kontyû, $32: 449$.

Rhynchaeninae sensu Klima, 1935, Col. Cat., 145, Rhynchaeninae : 1. plus Dinorrhopalini Voss, 1936, Arb. morph. tax. Ent. Berlin-Dahlem, $3: 110$.

The subfamily Rhynchaeninae treated in this paper are characterized by the following points :

\section{Adults :}

1. Hind femora much thicker than the anteriors.

2. Eyes large and convex from the outline of head.

3. Hind tibiae not uncinate nor mucronate, corbel lying entirely on the outer edge, not oblique in position.

4. Posterior margins of second to fourth ventrites curved posteriorly at sides, suture between first and second ventrites complete.

5. Claws separated and appendiculate.

Larvae :

1. Head retracted, deeply and broadly emarginate at posterior margin, front piece 

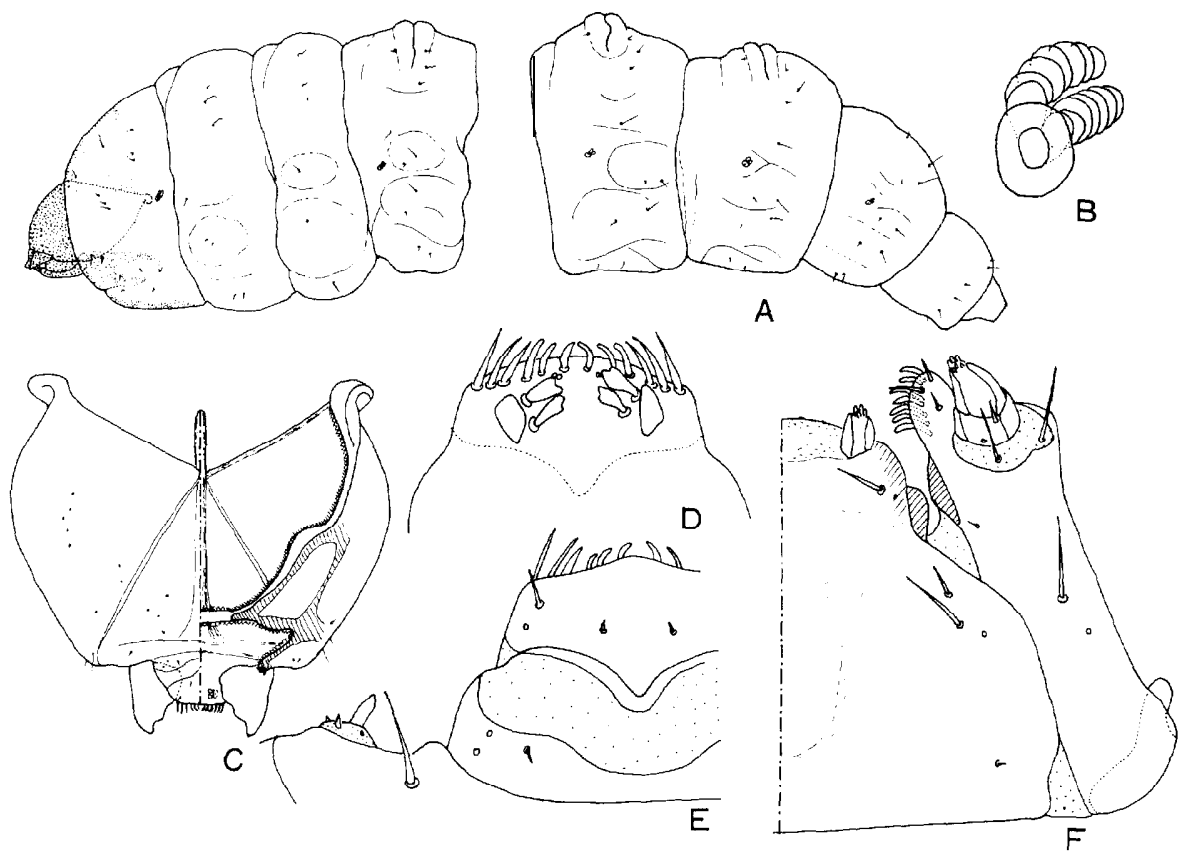

Fig. 1. Rhynchaenus japonicus (Hustache), mature larva. A : Lateral. B : Prothoracic spiracle. C : Head, dorsal and ventral. D : Epipharynx. E : Clypeus and labrum. F: Maxilla and labium (left half).

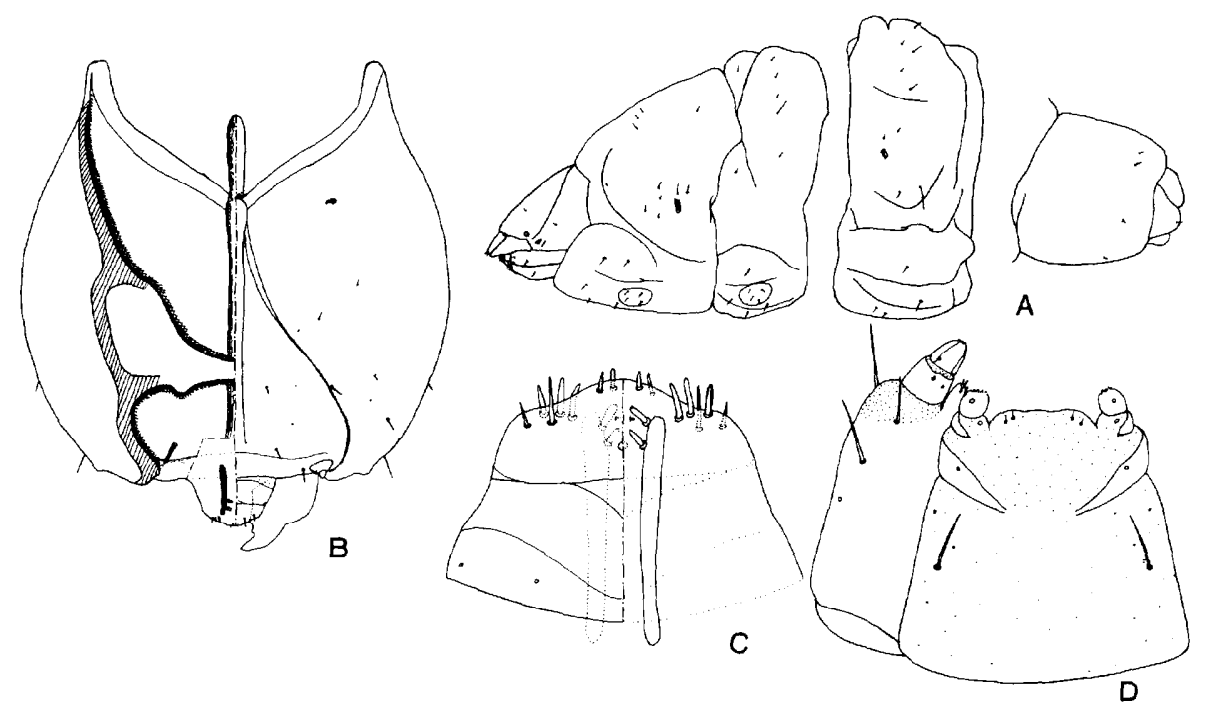

Fig. 2. Ixalmanigniventris Kôno, mature larva. A : Parts of body, lateral. B : Head, dorsal and ventral. C: Epipharynx, clypeus and labrum. C: Maxilla and labium. 

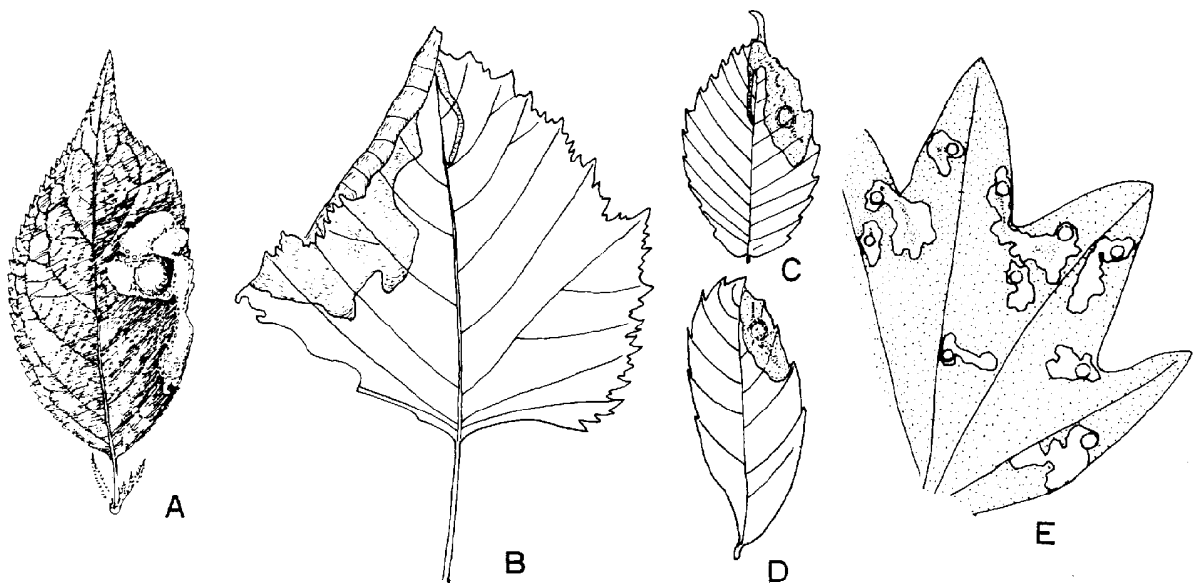

Fig. 3. The infested leaves. A: Prunus salicina Lindley by Dinorhopala takahashii (Kôno). (After Takahashi, 1930) B : Euptelea polyandra Sieb. et Zucc., by Ixalma nigriventris Kôno. C : Zelkova serrata(Thunb.) by Rhynchaenus sanguinipes (Roelofs). D : Quercus salicina Blume by Rhynchaenus galloisi (Kôno). E : Acer mono Maxim. by Rhamphus hisamatsui Chûjô et Morimoto.

very pointed and about reaching occipital foramen, endocarina long and reaching posteriorly far beyond posterior end of epicranial halves near the middle.

2. Hypopharyngeal bracon absent.

3. Labial palpi widely separated.

\section{Biology :}

1. The larvae are the leaf-miners.

2. They pupate in the mines.

3. The eggs are laid in the shallow holes made in the midrib or the hollows by the midrib on the underside of leaves.

The larvae of the leaf-mining insects such as Chrysomelidae, Buprestidae and some Microlepidoptera have similar heads with deep emargination at posterior end, but the prominent endocarina is characteristic in the subfamily Rhynchaeninak. I have examined the larvae of some leaf-mining weevils of the genera Deporaus, Ochyromera and Endaeus. Their heads are normally rounded posteriorly and they pupate in the soil. The absence of the hypopharyngeal bracon in head is characteristic to this subfamily in the family Curculionidae.

\section{KEY TO TRIBES}

1(1): Adults: Eyes lateral, strongly convex, forehead between eyes at least half as wide as the base of rostrum. Rostrum directing anteriorly. Hind femora each with a large pectinate tooth, femoral apodeme lacked. Larvae : Labial palp one-segmented.

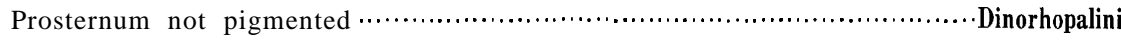

2(1): Adults : Eyes closely approximate on forehead. Rostrum perpendicular to the axis of body or received upon breast in repose. Hind femora with or without denticles 
along posterior margin externally from the middle, with apodeme. Larvae : Labial palp two-segmented. Prosternum with three pigmented spots

. Rhynchaenini

Tribe DinORHOPALINI

Dinorrhopalina Voss, 1936, Arb. morph. tax. Ent. Berlin-Dahlem, 3 : 110 (as a subtribe of Tachygonini).

Dinorrhopalini Voss, 1958, Decheniana, Beihefte $5: 101$ (as a tribe of Anthonominae). -Morimoto, 1963, J. Fac. Agr., Kyushu Univ., $12: 42$ (as a tribe of Rhynchaeninae). -Morimoto, 1964, Kontyû, 32: 449.

\section{KEY то GENERA}

1( 2 ): Rostrum very short, broader than long. Antennae inserted between eyes, not geniculate. Fore and mid tibiae each with a hook-shaped uncus born from the dorsal edge ; inner apical edge of hind tibia pointed. Aedeagus with tegmen Yshaped, parameres absent, internal sac of penis without flagellum $\cdots$ Dinorhopala Pascoe

2(1): Rostrum at least as long as wide. Antennae inserted into rostrum, geniculate. Fore and mid tibiae each with a oblique uncus born from the inner edge ; inner apical edge of hind tibia rounded. Aedeagus with tegmen ringed, with a pair of parameres, internal sac of penis with long flagellum, which coiled in repose

Ixalma Pascoe
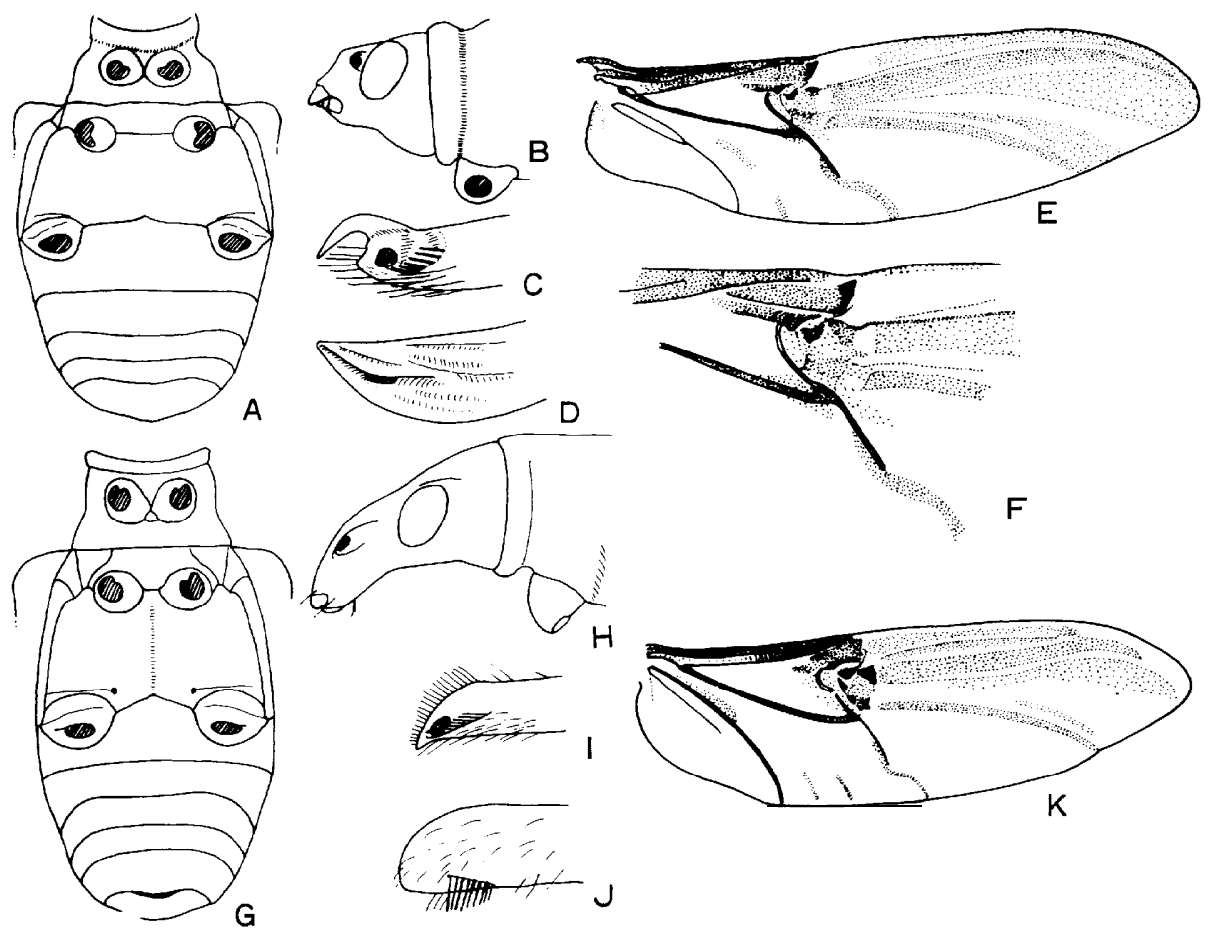

Fig. 4. A-D : Dinorhopalatakahashii (Kôno), G-K :Ixalma dentipes (Roelofs). A, G : Body, ventral. B, H : Head. C, I : Apex of fore tibia. D, J : Apex of hind tibia. E, K : Hind wing. F : Median part of E, enlarged. 


\section{Dinorhopala Pascoe}

Dinorhopala Pascoe, 1860, Journ. Ent., I : 61 (Type-species : Dinorhopala spinosa Pascoe, 1860, by monotypy). -Lacordaire, 1866, Gen. Col., VII : 169.

Dinorrhopala: Gemminger et Harold, 1871, Cat. Col., VII : $169 . \quad$-Klima, 1936, Col. Cat., 146, Tachygoninae : 3. - Voss, 1941, Mitt. Münch. Ent. Ges., $31: 900$, note (= Togezo). -Morimoto, 1963, J. Fac. Agr., Kyushu Univ., $12: 43$.

Togezo Kôno, 1930, Ins. Mats., V : 3 (Type-species: Togezo takahashii Kôno, 1930, by original designation). -Csiki, 1936, Col. Cat., 149, Cossoninae : 195. -Marshall, 1937, Proc. R. ent. Soc.London, B. $6: 58$ (Tachygoninae).

This genus contains six species from the Oriental Region at present. The type-species of the genus, spinosa, is different from the others according to the description and illustration in the following points : the pronotum is subtriangular and lobed at the base, and the hind femur armed with a strong tooth, which is not pectinate.

\section{Dinorhopala takahashii (Kôno)}

Togezo takahashii Kôno, 1930, Ins. Mats., V :3 (Tokio). -Iga, 1955, Col. Ill. Ins. Jap., Col.: 220, pl. 68, fig. 1571.

Togeto Takahashii: Csiki, 1936, Col. Cat., 149, Cossoninae: 195.

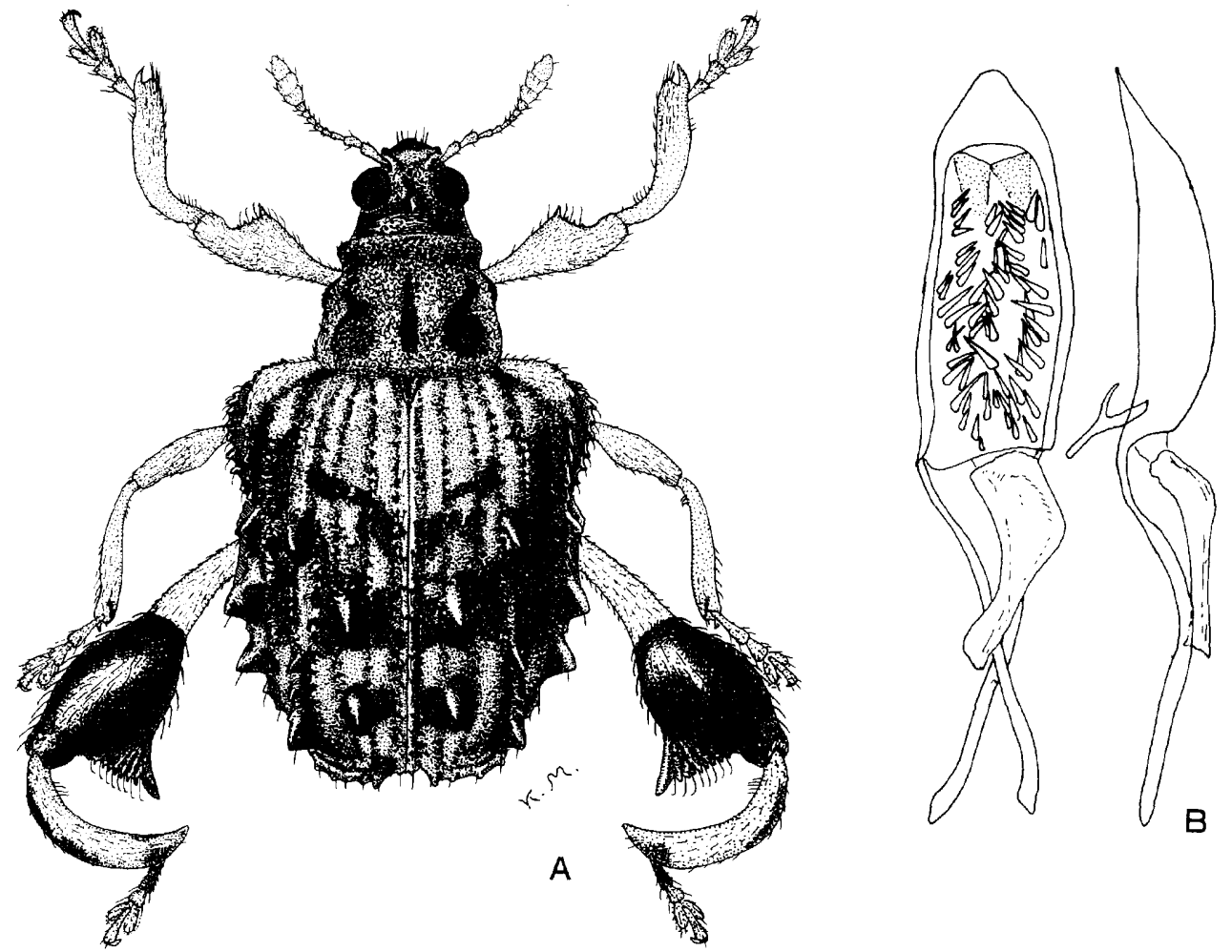

Fig. 5. Dinorhopala takahashii (Kôno). A : Male. B : Penis. 
Dinorrhopala takahashii: Voss. 1956, Akitu, V : 15 (Gumma). -Iga, 1956, Col. Ill. Ins. Jap., Col.: 220, pl. 68, fig. 1571. -Ohno, 1957, Shin Konchu, 10(1): 46 (Saitama ; biology, egg). -Kuroko, 1957, Kontyû, 25 : 109 (Mt. Hiko ; biology). -Morimoto, 1962, Sci. Bull. Fac. Agr., Kyushu Univ., 19 : 187 (Honshu, Shikoku, Kyushu).

Dinorhopala takahashii : Nakane. 1963, Icon. Ins. Jap. col. nat. ed., II: 377. pl. 189, fig. 11. -Morimoto, 1984, Col. Jap., IV : 292, pl. 57, fig. 30.

Gen. sp.? (Sumomo-hamogurizomushi), Takahashi, 1930, Kaju Gaichu Kakuron, I : 575 (biology).

Reddish brown ; vertex, basal margin of head, five patches on pronotum, scutellum, many patches on elytra and ventral surface, and swollen part of hind femora black.

Head short, transverse, transversely wrinkled, with a median fovea, forehead between eyes $2 / 3$ times an wide as the base of rostrum with a shallow median sulcus. Eyes strongly convex. Rostrum very short, lumped on each side above antennal socket. Antennae inserted in the base of rostrum between eyes, not geniculate, scape and first segment of funicle strongly clavate, the latter 1.5 times as long as second, third segment of funicle as long as wide, fourth to seventh transverse and successively a little wider distally, club compact, about as long as four basal segments of funicle combined.

Prothorax $4 / 5$ times as long as wide, side margins sinuate in the middle, subapical constriction well marked, basal margin flat U-shaped, disk rugulose, with a postmedian oblong fovea and a pair of transverse depressions in the middle. Scutellum subtriangular. Elytra widest on humeri, third, fifth and seventh intervals with large spines, seventh and eighth intervals around humeri and posterior half of tenth interval with small spines. Male pygidium with short median carina. Undersurface densely punctate, each puncture bearing a fine greyish seta.

Male aedeagus as figured, tegmen not ringed, Y-shaped, parameres absent, penis with internal sac spinous.

Length : 4.3-4.5 mm. (excl. rostrum).

Specimens examined: Kurokawa, Niigata Pref., one male, 28. iv. 1973, and one male, 30. v. 1973, K. Baba leg. Iozen, Kanazawa, Ishikawa Pref., one female, 25. v. 1974, T. Mikage leg. Tosayama, Kochi Pref., one male, 23. iv. 1950, H. Kashiwabara leg.

Distribution : Japan (Honshu : Yamagata, Niigata, Gumma, Saitama, Tokyo, Shizuoka, Aichi, Ishikawa, Fukui ; Shikoku :Kochi; Kyushu : Fukuoka).

BIology: The adults feed on the leaves of Prunus spp. and the larvae feed singly forming irregular blotch-like mines in the leaves of Prunus jamazakura and P. salicina (Yamazakura and Sumomo in Japanese) in June. They usually stay in the median swollen brownish chamber and feed on the other parts with making minute holes along the edge of the mines, and pupate in it. The new adults appear in late June to July.

\section{Ixalma Pascoe}

Ixalma Pascoe, 1871, J. Linn. Soc., Zool., XI : 214 (Type-species: Ixalma rufescens Pascoe, 1871, by monotypy). -Faust, 1894, Ann. Mus. Civ. Genova, 2, XIV(XXXIV):84(232). -Kôno, 1930, Ins. Mats., V : 2 (Japanese spp.). -Kôno, 1937, Trans. Sapporo Nat. Hist. Soc., XV : 29 (Japanese spp.). -Klima, 1936, Col. Cat., 146, Tachygoninae : 3. -Voss, 1949, Ent. Blätt., $41-44: 161$ (key to spp.). - Voss, 1958, Decheniana, Beihefte $5: 101$ (key to Fukien spp.). -Morimoto, 1960, Ins. Mats., $23: 46$ (rev. Japanese spp.). 
Ixelma Lewis, 1879, Cat. Col. Jap. Archip.: 22.

Celia Roelofs, 1874, Ann. Soc. Ent. Belg., XVII : 126 (Type-species : Celia dentipes Roelofs, 1874, by monotypy). -Faust, 1894, Ann. Mus. Civ. Genova, 2, XIV(XXXIV) : 84.

Xenopus (olim Celia) Roelofs, 1874, Ann. Soc. Ent. Belg., XVIII : pl. 1. -Csiki, 1936, Col. Cat., 149, Cossoninae : 195 .

This genus contains 14 species known to occur in the Oriental Region, and one species is newly described from Japan. The fresh adults are covered with yellowish powder.

\section{KeY to SPECIES}

1(4): Rostrum at most as long as wide. Scape of antennae reaching posteriorly a little beyond hind margin of eye and incurved. 3.5-4.0 $\mathrm{mm}$ in length.

2(3): Yellowish brown to reddish brown. Elytra not tuberculate. Fore and mid femora

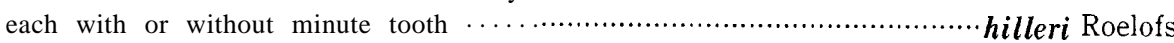

$3(2)$ : Brownish black. Elytra with third interval at the middle, fifth interval just before the middle and near the base tuberculate. Fore and mid femora each with a tooth and a subsidiary denticle

memnoniasp. nov.

4(1): Rostrum two or three times as long as wide. Scape of antennae straight and at most reaching the hind margin of eye. Pronotum black or with a longitudinal black stripe on each side.

5(8): Elytra tuberculate. Pronotum with a black stripe on each side. Male metasternum with a pair of tubercles. Rostrum twice as long as wide.

6(7): Elytra with third interval tuberculate at the middle, basal $1 / 3$ of fifth interval more or less elevated ; posterior part of elytra often infuscate $\cdots \cdots \cdots \cdots \cdots \cdots \cdots$. dentipes (Roelofs)

7(6): Elytra with third and fifth intervals tuberculate, the former in the middle and the latter a little before the middle, base of fifth interval weakly elevated, unicolored

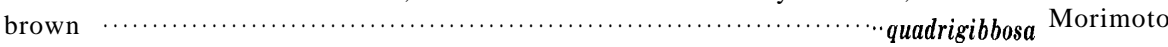

$8(5)$ : Elytra not tuberculate.

9 (10): Rostrum long, about three times as long as wide. First segment of antennal club a little longer than wide. Reddish brown, side margins of pronotum dark brown guttulum Kôno

10(9): Rostrum twice as long as wide. First segment of club a little shorter than wide.

11(12): Pronotum and underside entirely black, elytra each with a black spot on declivity of fifth interval and with a longitudinal black streak on the lateral margin. Forehead

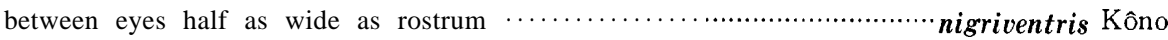

12(11): Reddish brown, pronotum with black sides, often elytra with dark lateral stripe and meso- and metasterna infuscate. Forehead between eyes a little narrower than the base of rostrum

okadai

Kôno

\section{Ixalma hilleri Roelofs}

Ixalma Hilleri Roelofs, 1879, Ann. Soc. Ent. Belg., compt. rend.: 54 (Japon). -Roelofs, 1880, Ann. Soc. Ent. Belg., XXIV : 18. -Faust, Ann. Mus. Civ. Genova., 2, XIV(XXXIV): 84.

Ixalma hilleri : Kôno,1937, Trans. Sapporo Nat. Hist. Soc., XV : 32. - Voss, 1949, Ent. Blätt., 41-44 : 163. -Kôno, 1950, Icon. Ins. Jap. : 1269, fig. 3658. -Hayashi, 1959, Ill. Ins. Larvae Jap. : 527, fig. 995 (larva, biology). -Morimoto, 1960, Ins. Mats., 23 : 47 (Honshu,Shikoku,Kyushu, AmamiOshima). $\quad$-Morimoto, 1984, Col. Jap., IV : 295, pl. 58, fig. 1.

Yellowish brown to reddish brown, antennae, legs excepting the swollen part of femora paler, pronotum with a pair of indistinct brownish patches, elytra often with brownish indistinct fasciae, the anterior fascia just before the middle and the posterior 
one between subapical calli.

Head densely punctate, temples parallel-sided, forehead between eyes a little narrower than the base of rostrum and as wide as the interscrobal distance, flat, with a small median fovea. Rostrum as long as or a little longer than wide. Antennae slender, scape reaching posteriorly beyond eye and weakly incurved. Prothorax 1.3 times as wide as long, sides slightly constricted in the middle, subapical constriction well marked, disk densely punctate and weakly rugulose, with a pair of depressions. Scutellum oval.

Elytra 1.5 times as long as wide, almost parallel-sided from humeri to the middle, humeral callus not prominent, ninth and tenth intervals each with a row of granules.

Fore and mid femora unarmed or each with a minute tooth. Metasternum sparsely puncticulate and finely wrinkled. Venter slightly puncticulate and wrinkled. Fifth ventrite slightly depressed or flattened and transversely wrinkled in male, slightly convex and indiscernibly wrinkled in female.

Aedeagus with penis parallel-sided and suddenly narrowed at apex, with small round projection at tip.

Length : 3.5-4.0 $\mathrm{mm}$.

Specimens examined : 39 exs. from Tokushima (Jinryo), Kochi (Is. Okinoshima), Fukuoka (Mt. Fukuchi, Mt. Hiko, Hata near Kurosaki, Mt. Ichinotake, Mt. Kanayama), Is. Amami-Oshima, Is. Ishigaki, Taiwan (Alishan, Lishan, Sungkang).

Distribution : Japan (Honshu, Shikoku, Kyushu, Is. Amami-Oshima, Is. Ishigaki), and Taiwan.

B Iology : The larvae make blotch-like mines along the edge of the leaves of Kadsura japonica (Sanekazura in Japanese), hibernate in the mines and pupate from late April to early May in the mines. New adults emerge in the middle and late May. The adults were collected in June and July on the leaves of this plant. The eggs are generally laid on the underside of the leaves.

The specimens from Taiwan are generally reddish brown and their anterior four femora are armed each with a minute triangular tooth. Those from Amami-Oshima have the similarly armed femora, and the second interval of the eiytra is a little narrower than the third, the latter is often weakly convex in the median part.

This species is close to miniata Voss, 1949, from Fukien, China, but the fore and mid femora of the latter are armed with "kräftigen Zahn, der aussen gekerbt ist".

\section{Ixalma memnonia sp. nov.}

Brownish black, rostrum, antennae and legs excepting distal half of hind femora reddish brown. Derm with sparse prostrate grey pubescence.

Head to the anterior margin of eyes as long as wide, parallel-sided behind eyes, forehead between eyes with a median fovea, as wide as the interscrobal distance. Rostrum as long as wide, lumped on each side above antennal sockets, weakly costate longitudinally between the lump and inner margin of eye on each side, the intercostal area weakly depressed and punctate, anterior area before the lump impunctate. 
Antennae inserted in the middle of rostrum, scape reaching posteriorly a little beyond eye and evenly incurved, distinctly longer than funicle, clavate at apex, first segment of funicle clavate, as thick as scape, a little longer than second, which 1.5 times as long as third, fourth to sixth as long as wide, seventh a little longer than wide, club slender, first segment a little longer than wide and slighly longer than second, the latter slightly wider than long.

Pronotum slightly wider than long (15:13), widest at the base, faintly constricted in the middle, subapical constriction well marked, depressed on each side at the middle, with a short median weak sulcus behind the middle, disk densely punctate, interspace between punctures minutely granulate, transversely wrinkled near the basal margin. Scutellum oval, median area depressed and punctate.

Elytra 1.6 times as long as wide, parallel-sided from humeri to the middle, third interval at the middle, fifth interval just before the middle and near the base each with a tubercle, first interval conjointly slightly raised on declivity, fifth interval costate at subapical callus.

Pygidium densely punctate. Metasternum rugulose. First and second ventrites weakly rugulose at base, the rest of venter finely wrinkled, fifth ventrite densely punctate and rugulose in male. Fore and mid femora each armed with two teeth, the outer one small. Hind femora armed with large triangular pectinate tooth, outer margin of the tooth with eight denticles.

Length : 3.6-4.0 mm. (excl. rostrum).

Holotype male (Type No. '2453, Kyushu Univ.), Mt. Omotodake, Is. Ishigaki,
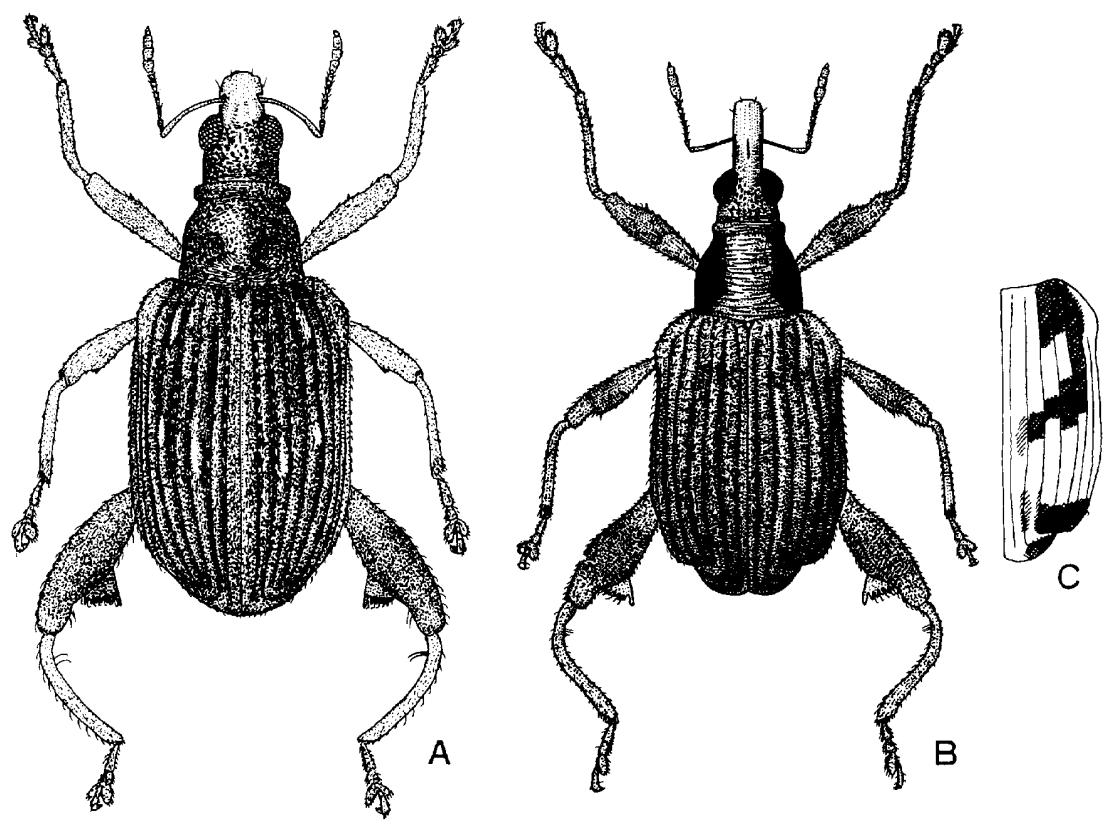

Fig. 6. A : Ixalma memnonia sp. nov., male. B : Ixalma kadai Kôno, immaculate form. C : id. elytron of maculate form. 
Ryukyus, 18-21. iv. 1975, H. Irie leg.

Paratypes : Same locality as holotype, two females, B-11. iv. 1975, H. Irie leg. ; one male, 28. iv. 1974, 0. Tamura leg.

Distribution : Japan (Is. Ishigaki).

Biology : Unknown.

This new species has a close relation with hilleri Roelofs and miniata Voss in having the short rostrum, long antennal scape, and parallel-sided elytra on basal half, but characteristic in the tuberculate elytra and the teeth of anterior four femora.

\section{Ixalma dentipes (Roelofs)}

Celia dentipes Roelofs, 1874, Ann. Soc. Ent. Belg., XVII : 127 (Tango). -Faust, 1894, Ann. Mus. Civ. Genova, 2, XIV(XXXIV) : 84.

Xenopus (olim Celia) dentipes : Roelofs, 1875, Ann. Soc. Ent. Belg., XVIII, pl. 1, fig. 2. -Csiki, 1936, Col. Cat, 149, Cossoninae : 195.

Ixalma dentipes : Lewis, 1879, Cat. Col. Jap. Archip.: 22. -Kôno, 1930, Ins. Mats., V :2 (Kioto).

-Kôno, 1937, Trans. Sapporo Nat. Hist. Soc., XVI : 29 (Honshu, Shikoku). -Voss, 1949, Ent.

Blätt., 41-44 : 164. -Ohno, 1954, Shin Konchu, 7 (13) : 27 (Gumma, Wakayama). -Morimoto, 1955, Shin Konchu, 8 (3) : 46 (Oita, Fukuoka). -Morimoto, 1960, Ins. Mats., $23: 48$ (Honshu, Shikoku, Kyushu). -Morimoto, 1984, Col. Jap., IV : 295, pl. 58, fig. 2.

Reddish brown, pronotum with a pair of blackish longitudinal stripes, swollen part of hind femora dark brown, posterior part of elytra often infuscate.

Head densely punctate, with a pair of oblique carinae, forehead with a median fovea, slightly narrower than interscrobal distance. Rostrum twice as long as wide, evenly curved. Antennae inserted before the middle of rostrum, scape straight, reaching the hind margin of eye, slightly longer than funicle.

Pronotum slightly wider than long (15:13), subapical constriction and a pair of depressions weaker. Scutellum subtriangular, a little longer than wide, with a few punctures.

Elytra 1.5 times as long as wide, parallel-sided from humeri to subapical swellings, third interval with a tubercle in the middle, fifth interval costate on basal $1 / 3$, seventh interval strongly costate at base forming humeral callus, fifth interval weakly and seventh interval strongly costate at subapical swelling.

Metasternum with a pair of small tubercles in male. Teeth of anterior' four femora sharp and with two subsidiary denticles externally. Teeth of hind femora pectinate, with seven to eight denticles.

Length : 4.3-5.5 $\mathrm{mm}$.

SPECIMENS EXAMINED: 18 specimens from Aomori (Towada), Nagano (Karuizawa), Yamanashi (Masutomi), Kyoto (Kibune), Osaka (Minoo), Okayama (Kibi), Fukuoka (Mt. Hiko, Mt. Fukuchi, Mt. Wakasugi, Magaribuchi, Mt. Kanayama, Mt. Inunaki, Mt. Korasan), Nagasaki (Mt. Iwayasan), and Oita (Mt. Sobo).

Distribution: Japan (Honshu, Shikoku, Kyushu).

Biology : The adults were captured on the leaves of Callicarpa japonica and Kadsura japonica (Murasakishikibu and Sanekazura in Japanese). 
This species is very close to klapperichi Voss and the specimens with well developed humeral calli agreed with it.

\section{Ixalma quadrigibbosa Morimoto}

Ixalma quadrigibbosus Morimoto, 1960, Ins. Mats., 23 : 48 (Honshu, Kyushu ; Type-locality : Hirakura, Mie Pref.).

Ixalma quadrigibbosa : Morimoto, 1962, Sci. Bull. Fac. Agr., Kyushu Univ., 19 : $188 . \quad$-Nakane, 1963, Icon. Ins. Jap. col. nat. ed., II : 377, pl. 189, fig. 10. -Morimoto, 1984, Col. Jap., IV : 295, pl. 58, fig. 3.

Reddish brown, swollen part of femora dark brown, pronotum with a black longitudinal stripe on each side.

Head with a pair of oblique carinae from the inner margin of eyes. Rostrum twice as long as wide. Antennae insertred in the middle of rostrum, scape straight, reaching behind the middle of eye.

Pronotum and scutellum as in dentipes. Elytra 1.4 times as long as wide, parallel-sided from humeri to the middle, then weakly curved to the subapical swellings, third interval in the middle and fifth interval just before the middle each with a tubercle, basal $1 / 4$ of third and fifth intervals convex.

Fore and mid femora armed each with a sharp tooth and subsidiary two or three denticles externally. Metasternum with a pair of tubercles in male, which are much larger than those in dentipes.

Length : 5.5-6.1 mm.

Specimens EXAmined : 16 exs. from Mie (Hirakura), Hiroshima (Gokurakuji), and Fukuoka (Mt. Hiko, Mt. Fukuchi).

Distribution : Japan (Honshu, Shikoku, Kyushu).

Biology : Mr. H. Ichihashi collected some specimens from Illicium religinosum (Shikimi in Japanese) in Mie.

This is very close to dentipes, but easily separable from it by the characters noted in the key.

\section{Ixalma okadai Kôno}

Ixalma okadai Kôno, 1937, Trans. Sapporo Nat. Hist. Soc., XV : 30, f.1 (Type-locality : Mt. Taisen ;

Mt. Takao). - Voss, 1949, Ent. Blätt., 41-44 : 164. -Kôno, 1950, Icon. Ins. Jap. : 1269, f. 3659,

-Ohno, 1954, Shin Konchu, 7 (13) : 27 (Saitama, Shizuoka ; biology). -Morimoto, 1960, Ins.

Mats., 23 : 51 (Honshu, Kyushu). -Morimoto, 1984, Col. Jap., IV : 295, pl. 58, fig. 6.

Variable in coloration ; in brownish examples, reddish brown with blackish lateral margins of pronotum, swollen part of hind femora dark brown ; in maculate specimens, vertex, side margins of pronotum, and meso- and metasterna black, elytra with blackish patches as in fig. 6, C.

Head with weak oblique carinae above eyes. Rostrum twice as long as wide. Scape of antennae reaching the middle of eye.

Pronotum slightly wider than long, subparallel from the base to the middle, then weakly rounded and narrowed anteriorly, subapical constriction weak, dorsolateral 
depressions obsolete, disk transversely wrinkled. Scutellum oval, with a few punctures in the middle.

Elytra $10 / 7$ times as long as wide, widest at posterior third, third and fifth intervals weakly costate.

Fore and mid femora each armed with a sharp tooth and subsidiary one or two minute denticles externally. Pectinate tooth of hind femora with seven to eight denticles.

Length: $3.3-4.7 \mathrm{~mm}$.

Specimens examined : 16 exs. from Aomori (Towada), Niigata (Tsugawa), Saitama (Urayamadani), Tokyo (Mt. Takao), Fukui (Eiheiji), Aichi (Mt. Mongusan), Nagano (Shimashimadani), and Oita (Mt. Sobo).

Distribution : Japan (Honshu, Kyushu).

B Iology : The larvae mine the leaves of Meliosma tenuis and M. myriantia (Miyamahoso and Awabuki in Japanese).

\section{Ixalma nigriventris Kôno}

Ixalmanigriventris Kôno, 1937, Trans. Sapporo Nat. Hist. Soc., XV : 31, f. 2 (Type-locality : Hongawa, Kochi). -Kôno, 1950, Icon. Ins. Jap. : 1270, f. 3660. -Morimoto, 1953, Gensei, II : 44 (Tokushima). -Ohno, 1954, Shin Konchu, 7 (13): 27 (Saitama, Shizuoka ; biology). -Morimoto, -Morimoto, 1960, Ins. Mats., 23 : 51 (Honshu, Shikoku). -Nakane, 1963, Icon. Ins. Jap. col. nat. ed., II : 377, pl. 189, fig. 9. -Morimoto, 1984, Col. Jap., IV : 295, pl. 58, fig. 5.

Reddish brown, head excepting the latero-ventral sides, base of rostrum, prothorax and underside black, elytra with black side streak leaving reddish brown humeral callus, the streak widened dorsad just before the middle to fifth interval, often with blackish patch in the middle of second and third intervals, subapical swellings with black patch, which often widened laterally and connate to lateral streak, swollen part of hind femora with large black patch on dorsum.

Forehead between eyes half as wide as the base of rostrum, depressed. Rostrum twice as long as wide. Antennae inserted before the middle of rostrum, scape reaching the middle of eye. Pronotum a little wider than long, the sides weakly constricted at $1 / 3$ from the base, dorsolateral depressions obsolete, disk densely punctate, transversely rugulose. Scutellum oval, with a few punctures in the middle.

Elytra about 1.6 times as long as wide, widest in the middle, third interval slightly raised in the middle, fifth interval scarcely costate.

Fore and mid femora each with an obtuse tooth and two subsidiary denticles externally. Pectinate tooth of hind femora with seven to eight denticles.

Length : 5.5-6.1 mm.

SPECIMENS EXAMINED : 11 exs. from Tokyo (Okutama), Nagano (Shimashimadani), Tokushima (Jinryo), Kochi (Makiyama), and Ehime (Mt. Ishizuchi, Omogokei).

DistribUtion : Japan (Honshu, Shikoku).

Biology : I found the mature larvae, pupae and teneral adults in the mines made in the leaves of Euptelaea polyandra (Fusazakura in Japanese) in August 29, 1954, in 
Kochi (Makiyama).

\section{Ixalma guttulum Kôno}

Ixalma guttulum Kôno, 1928, Ins. Mats., II : 169, Taf. VI, f. 15 (Type-locality : Baibara, Taiwan), -Kôno, 1930, Ins. Mats., V :2. -Kôno, 1937, Trans. Sapporo Nat. Hist. Soc., XV : 31 . -Voss, 1949, Ent. Blätt.,41-44: $164 . \quad$-Morimoto, 1960, Ins. Mats., 23 : 51 (Amakusa, Kagoshima). -Imasaka et al., 1980, Niho no Mushi, (5) : 48 (Mt. Kurotake, Oita). -Morimoto, 1984, Col. Jap. IV : 295, pl. 38, fig. 4.

Reddish brown, side margins of pronotum dark brown, elytra often with brownish side streaks, which widened internally to fifth interval at the middle.

Head densely punctate, with a pair of oblique short carinae from the inner margin of eyes. Rostrum three times as long as wide. Antennae inserted just before the middle of rostrum, scape not reaching the middle of eye.

Pronotum slightly wider than long, the sides weakly constricted at $1 / 3$ from the base, dorsolateral depressions very weak, disk transversely wrinkled. Scutellum as in nigriven tris.

Elytra 1.4 times as long as wide, widest at apical 1/3, intervals each with a row of granules, which bears recumbent fine seta, the granules indistinct at basal area between fifth intervals, third interval in the middle and fifth interval before the middle weakly costate.

Fore and mid femora each armed with a sharp tooth and two subsidiary denticles. Pectinate tooth of hind femora with eight to nine denticles.

Length : 4.0-5.3 $\mathrm{mm}$.

Specimens examined : Kakuyama, Amakusa, one male, 13. ix. 1931, H. Hori leg. Mt. Eboshi, Taniyama, Kagoshima Pref., one male, 23. v. 1958, H. Maebara leg. Yangmingshan, Taiwan, one female, 25. v. 1965, K. Morimoto leg. Penpuchi, Taiwan, one female, 13. vii. 1966, H. Sasaji leg.

Distribution : Japan (Kyushu), Taiwan.

Biology : Unknown.

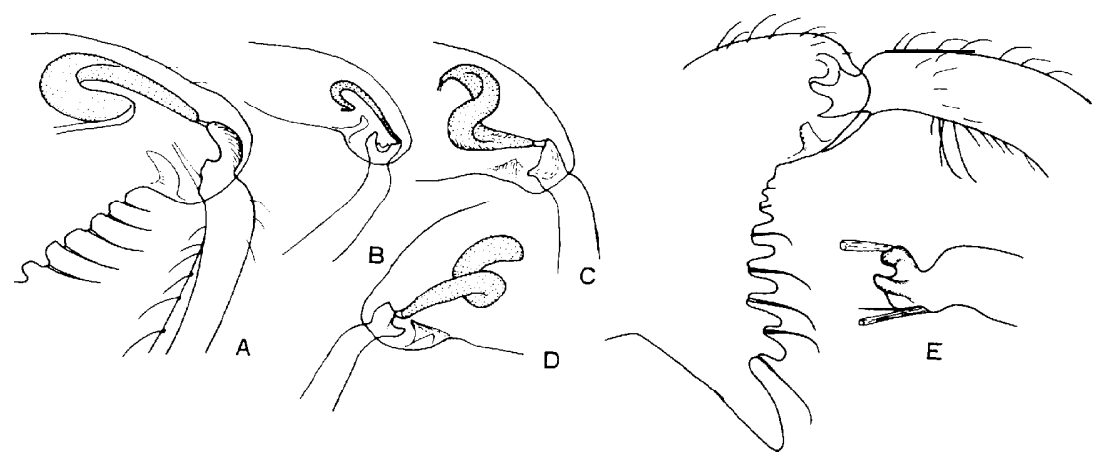

Fig. 7. Joints of hind femur and tibia, showing apodeme. A:Rhynchaenus(Orchestes) sanguinipes (Roelofs). B : Rhynchaenus (Isochnus) sorbi sp. nov. C, D : Rhamphus hisamatsui Chûjô et Morimoto. E : Ixalma hilleri Roelofs (apodeme absent). 
Tribe Rhynchaenini

Orchestina Thomson, 1859, Skand. Col., I : 141.

Rhynchaenini Bedel, 1884, Col. Bassin Seine, VI : 122.

Rhynchaeninae Winkler, 1932, Cat. Col. Reg. Pal., XIII : 1629. -Klima, 1935, Col. Cat., 145,

Rhynchaeninae: 1 .

The hind femora of the weevils in this tribe contain a special structure related to jumping, which is known in the Chrysomelidae as Maulik's organ or femoral apodeme. This structure is J-shaped in Rhynchaenus and Orchestoides and twisted in Rhamphus, and heavily sclerotized, while in the tribe Dinorhopalini no such structure is present.

\section{KEYTOGENERA}

1( 4): Tibiae unarmed at tip, tarsal groove ascended upwards to the base and forming entirely bare exterior surface. Club of antennae loosely segmented, as long as or a little shorter than funicle. Rostrum short, about twice as long as wide, perpendicular to the axis of body in repose, antennal scrobes oblique, reaching straightly to the base of ventral surface of rostrum. Prosternum before coxae canaliculate, fore coxae separated by flat prosternum. Mesosternal process about as wide as a coxa.

2(3): Forehead strongly convex from the outline of head, triangular between eyes, head transversely depressed behind eyes and at the base of rostrum ...... Orchestinus Morimoto

3(2): Forehead not convex from the outline of head, linear between eyes, head not

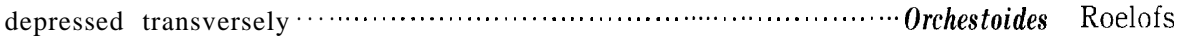

4(1): Fore and mid tibiae uncinate at tip. Rostrum longer, received upon breast in repose. Antennal club compact, at most as long as basal four segments of funicle combined. Prosternum before coxae not canaliculate.

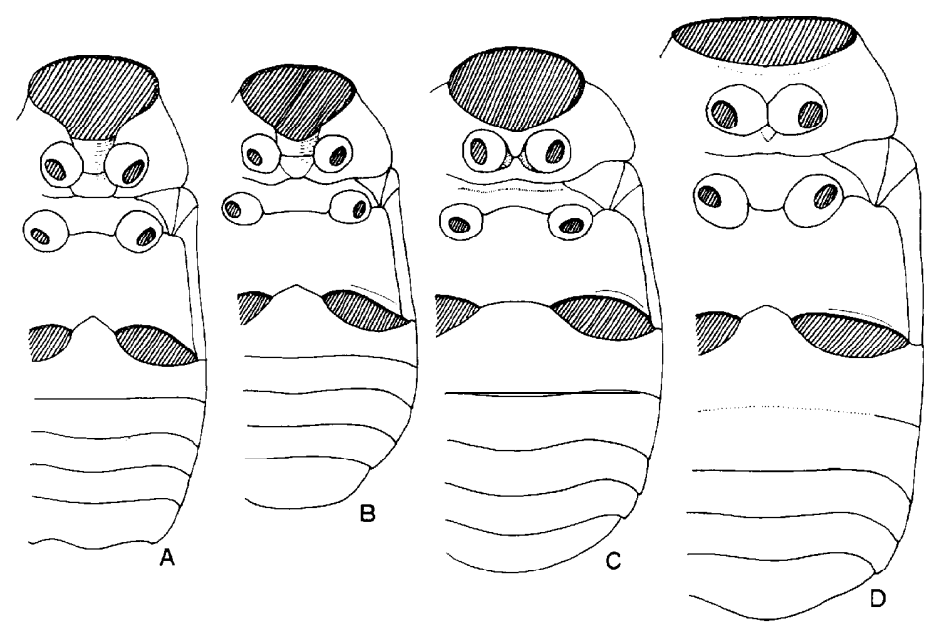

Fig. 8. Thorax and abdomen, ventral. A : Orchestoides decipiens Roelofs. B :Orchestinus oculatus Morimoto. C : Rhynchaenus (Nomizo) kamiyai sp. nov. D : Rhynchaenus (Tachyerges) salicis (Linnaeus). 
$5(6)$ : Forehead strongly bent between eyes and prominent anteriorly, antennae inserted in the lateral surfaces of prominence between eyes, scrobes absent. Antennae straight, first and second segments of club fringed with a row of setae along apical margins. Fore coxae separated by flat prosternum $\cdots \ldots \ldots \ldots \ldots \ldots \ldots \ldots \ldots \ldots \ldots$ Rhamphus Clairville

$6(5)$ : Forehead not prominent anteriorly, antennae geniculate, inserted into rostrum, club densely hairy

Rhynchaenus Clairville

\section{Rhamphus Clairville}

R hamphus Clairville, 1798, Ent. Helv., I : 104 (Type-species : Rhamphus flavicormis Clairville, 1798, designated by Schoenherr, 1826. = pulicarius Herbst, 1795).

Head strongly bent between eyes and thence forming flat surface to apex of rostrum. Eyes oblong-oval, approximate dorsally. Antennae inserted in the prominent forehead, straight, funicle seven-segmented, first segment large, first and second segments of club each fringed with a row of setae along anterior margin. Elytra rather flat, widest behind the middle. Pygidium invisible. Prosternum between fore coxae flat, as wide as the base of fore tibia. Mesosternal process and metasternum flat, the former about as wide as abdominal process between hind coxae. Venter flat, shiny. Femora unarmed, hind femora swollen, with apodeme. Fore and mid tibiae each armed with a hook-shaped uncus a little behind the apex dorsally. Hind tibiae simple, unarmed at apex.

This genus contains 17 species at present known to occur from the Palaearctic, Ethiopian and Australian Regions, and none from the Oriental Region.

\section{KEY TO SPECIES}

1(2): Derm bare, without hairs. Anterior face of eyes on the same level with the base of rostrum. Male aedeagus with penis rounded at apex, internal sac asperate with small spines, but not armed with stout spines …....................... pulicarius (Herbst)

2(1): Derm with fine hairs, each interval of elytra with a row of fine hairs. Anterior face of eyes on the level of the ventral surface of rostrum. Male aedeagus with penis triangular at apex, internal sac armed with stout spines $\cdots$ hisamatsui Chûjô et Morimoto

\section{Rhamphus pulicarius (Herbst)}

Curculio pulicarius Herbst, 1795, Naturs. Ins. Käf., VI : 429.

Rhamphus flavicornis Clairville, 1798, Ent. Helv., I : 104, fig. 12.

?Rhamphus flavicornis: Schönfeldt, Cat. Col. Jap. 2. Nachtr. : 266.

Rhamphus pulicarius: Oishi, 1927, Byochugai-zasshi, XIV : 692 (hosts, biology). -Nishitani, 1930, Aomori Nokaiho, (209) : 14 (biology). -Takahashi, 1930, Kajugaichu Kakuron, I : 405 (biology).

Rhamphus pullus Hustache, 1920, Bull. Mus. Hist. Nat. Paris, (6) : 635 (Type-locality : Chuzenji ; Tokio). -Kôno, 1930, Ins. Mats., V : 30. -Kôno, 1935, Ins. Mats., X : 62 (Is. Shikotan). —Voss, 1958, Decheniana, Beihefte $5: 108$ (China : Fukien). -Morimoto, 1959, Enum. Ins. Mt. Hiko : 84, pl. 4, fig. 4 (hosts). -Morimoto, 1962, Sci. Bull. Fac. Agr., Kyushu Univ. 19 : 187 (Hokkaido, Honshu, Shikoku, Kyushu, Kuril Isls., China). -Nakane, 1963, Icon. Ins. Jap. col. nat. ed., II : 378, pl. 189, fig. 20. -Morimoto, 1984, Col. Jap., IV : 296. Syn. nov.

Gen. sp. (Ringotobizomushi), Nishitani, 1920, Ins. World, XXIV(273) : 164 (Aomori, Akita, Yamagata).

Japanese species was distinguished from pulicarius of Europe by Hustache on ".. sa taille moindre, sa t\&e un peu plus allongée, les élytres moins fortement élargis en 

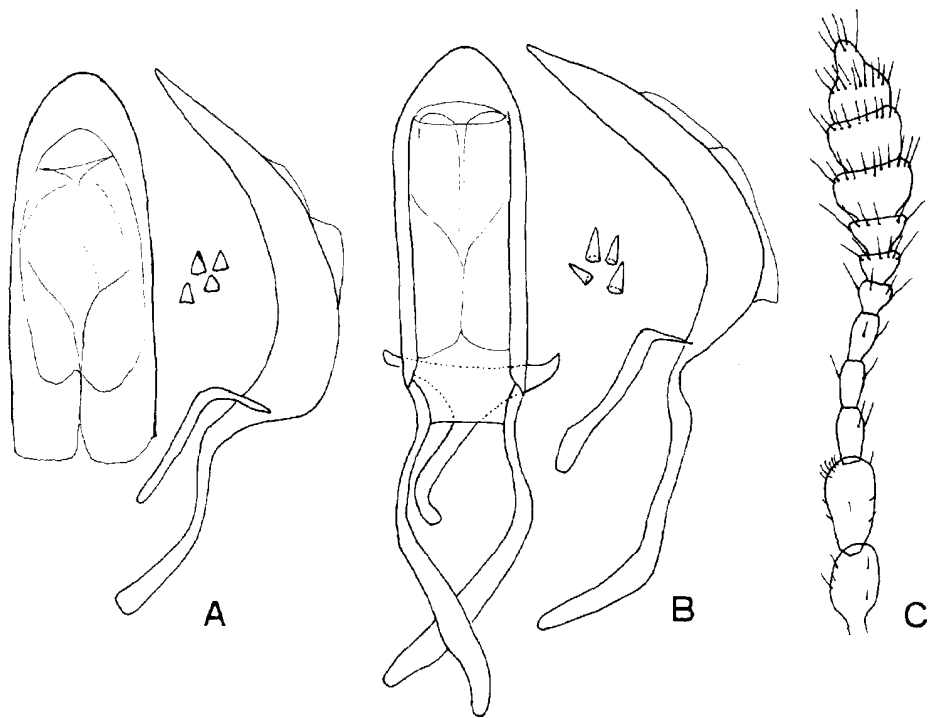

Fig. 9. Rhamphus pulicarius (Herbst). A, B : Aedeagus. C: Antenna. (A, C : Japan: Mt. Hiko ; B : Poland).

arriére". But I can not find any difference between Japanese and European specimens.

SpeCimens eXAmined : 96 exs. from Hokkaido (Wakkanai, Nibushi, Aizankei, Yukomambetsu), Aomori (Hachimantai), Niigata (Kurokawa, Mt. Yoneyama, Tsuchizawa), Tochigi (Nikko), Nagano (Mt. Asama, Shirahone), Tottori (Mt. Daisen), Tokushima (Mt. Tsurugi), Kochi (Mt. Kajigamori, Mt. Tebako, Mt. Kuishi), Fukuoka (Mt. Hiko), Tsushima, Quelpart Is. (Mt. Hanna), and Taiwan (Tayulin, Hualien Hs.).

Distribution: Japan (Hokkaido, Honshu, Shikoku, Kyushu, Tsushima), Korea, Taiwan, China, Kuril Isls., Sachalin, Siberia and Europe.

BIOLOGY : The adults feed on the leaves of Malus pumila, Prunus tomentosa, $P$. avium, Betula platyphylla var. japonica, Castanea crenata and Quercus acutissima (Ringo, Momo, Sakuranbo, Shirakanba, Kuri, and Kunugi in Japanese). The larvae have been collected from the leaves of Malus pumila. They hibernate in the larval form in the leaves, pupate in May and the new adults appear from May to June. The larva makes round brown mine from July.

\section{R hamphus hisamatsui Chûjô et Morimoto}

Rhamphus hisamatsui Châjô et Morimoto, 1960, Ent. Rev. Japan, XI : 4 (Is. Hachijo). -Kribolutskaya et al., 1978, Trud. Biol. -Pots. Inst., (n.s.) 50(153) : 101 (Kuril Isls.). -Morimoto, 1984, Col. Jap., IV : 296, pl. 58, fig. 10.

This species is easily distinguished from the known species of the genus by the vesture of dorsal surface and the spinous internal sac of penis.

SPECIMENS EXAMINED : 200 exs. from Hokkaido (Mt. Meakandake), Niigata (Kurokawa), Yamanashi (Mt. Senjo, Mt. Komagatake, Mt. Fuji), Nagano (Karuizawa), 
Kanagawa (Hakone), Ishikawa (Mt. Hakusan), Fukui (Kinometoge, Koike), Mie (Mie Univ. Forest), Kochi (Mt. Kajigamori), Fukuoka (Mt. Hiko), Kumamoto (Mt. Aso), Oita (Mt. Daisen), and Taiwan (Tsuifeng, Sungkang, Alishan, Penpuchi).

Distribution: Japan (Hokkaido, Honshu, Shikoku, Kyushu, Izu Isls.), Taiwan, and Kuril Isls.

Biology: The adults were captured on the leaves of Alunus firma, A. japonica, Betula ermanii, B. platyphylla var. japonica, and Acer mono (Yashabushi, Hannoki, Dakekanba, Shirakanba and Itayakaede in Japanese). The new adults were obtained by rearing the round blotchy mines of the leaves of Acer mono. This species is abundant in Izu Isls. on Alnus firma, but not found in the low land of Honshu, Shikoku and Kyushu.

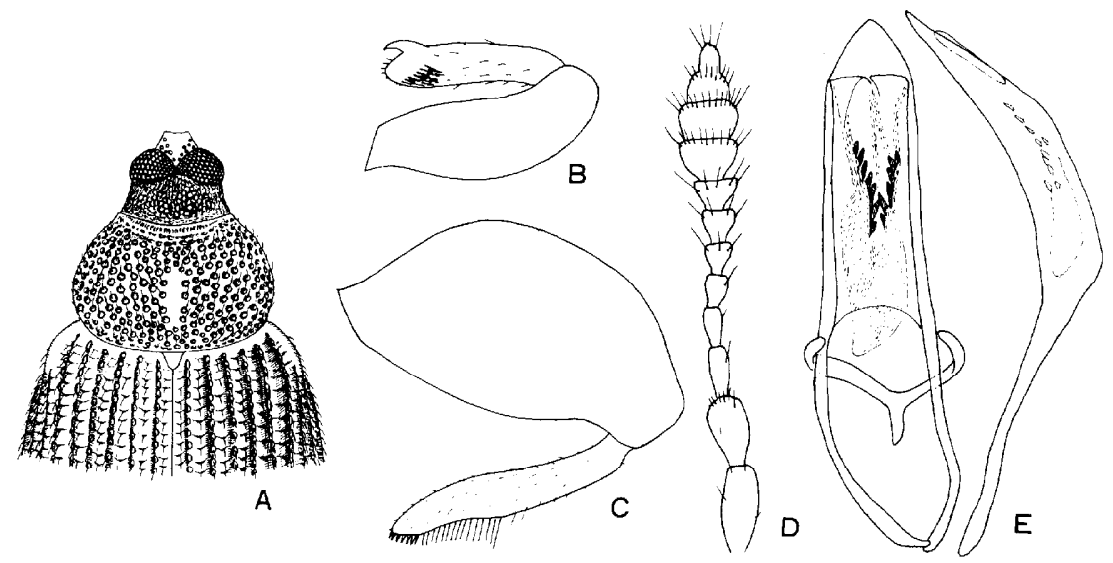

Fig, 10. Rhamphus hisamatsui Chûjô et Morimoto (from Is. Hachijo). A : Anterior part. B : Fore leg. C: Hind leg. D : Antenna. E : Penis.

\section{Orchestoides Roelofs}

O vchestoides Roelofs, 1875, Ann. Soc. Ent. Belg., XVIII : 191 (Type-species : Orchestoides decipiens Roelofs, 1875, by monotypy). -Kôno, 1930, Ins. Mats., IV : 21 . —Voss, 1953, Ent. Blätt., $49: 65$. -Voss, 1958, Decheniana, Beihefte $5: 103 . \quad$-Morimoto, 1962, J. Fac. Agr., Kyushu Univ., $12: 43$. -Morimoto, 1964, Kontyû, 32 : 451. -Morimoto, 1984, Col. Jap., IV : 295.

Forehead between eyes linear, with a row of hairs. Rostrum perpendicular to the axis of body in repose, straight, about twice as long as wide, antennal scrobes oblique, their dorsal margin reaching straightly to the base of the underside of rostrum and distant far from eyes. Antennae geniculate, scape about as long as or a little shorter than funicle, funicle seven-segmented, club almost as long as funicle. Prosternum before coxae canaliculate bordering laterally with carinae, inside of the canal hairy, anterior margin deeply sinuate. Fore coxae separated, lying on the middle of prosternum. Mesosternal process as wide as a coxa. Femora unarmed, hind femora with apodeme. Tibiae nearly straight, unarmed at tip, tarsal groove ascended upwards to the base forming entirely bare exterior surface. 
This genus contains six species known to occur in Japan, China and Taiwan, and key to species was given by Morimoto, 1964.

This is close to Imachra Pascoe, 1873, and Copidorrhinus Marshall, 1948, in having the robust rostrum with oblique scrobes, canaliculate prosternum before coxae, distant fore coxae, unarmed tibiae at apex, and tarsal groove of tibiae which ascended to the base forming bare surface externally. These genera were originally described in the Anthonominae and Imachra was transferred to the Rhynchaenini by Voss, 1953. Hyporhynchaenus Voss, 1940, described as a subgenus of Rhynchaenus is also similar in having the distant fore coxae, loosely segmented club of antennae, and robust rostrum, but his description does not contain further information. Several undescribed species from Thailand, East Malaysia and Taiwan in the collection of Kyushu University have intermediate characters of the above mentioned genera, and the generic designation given here is tentatively followed after Voss, 1953 \& 58.

\section{KEY TO SPECIES}

1(2): Entirely reddish brown to rusty red, elytra with the apical and lateral margins, and pronotum with lateral margins broadly covered with greyish hairs, the greyish area marginate internally with dark brown to blackish hairs on elytra. Body slender, pronotum about as long as wide, anterior margin slightly narrower than the posterior margin, elytra $1.8-1.9$ times as long as wide …......................ma matai Morimoto

2(1): Black to dark brown, elytra with greyish bands. Body oval, pronotum transverse, elytra at most 1.5 times as long as wide.

3(4): Elytra oval, broadest behind the middle, 1.35-1.39 times as long as wide, with yellowish grey postscutellar patch and four greyish bands $\ldots \ldots \ldots \ldots \ldots$ shirozui Morimoto

4( 3): Elytra subparallel-sided or weakly curved laterally from humeri to the apical third, $1.45^{-1.50}$ times as long as wide, postscutellar patch absent.

5(6): Elytra with three greyish bands, basal band along hind margins continuous across first intervals behind scutellum, antemedian and postmedian bands more sinuate and denser

-decipiens Roelofs

6(5): Elytra with four greyish bands, basal band along basal margins usually interrupted on first intervals, antemedian and postmedian bands less sinuate, subapical band often separated into two patches

nipponicus Morimoto

\section{Orchestoides decipiens Roelofs}

Orchestoides decipiens Roelofs, 1875, Ann. Soc. Ent. Belg., XVIII : 192, pl. 3, fig. $15 . \quad$-Kôno, 1930, Ins. Mats., V : 30. -Voss, 1953, Ent. Blätt., $49: 65$ (China : Fukien). -Voss, 1958, Decheniana, Beihefte 5 : 104 (China : Fukien). -Nakane, 1963, Icon. Ins. Jap. col. nat. ed., II : 378, pl. 189, fig. 21. -Morimoto, 1964, Kontyû, $32: 455$, fig. 2. -Morimoto, 1984, Col. Jap., IV : 295, pl. 58, fig. 9 .

Specimens exAmined : 29 exs. from Kochi (Cape Ashizuri), Fukuoka (Mt. Fukuchi), Nagasaki (Mt. Kompira), Tsushima (Azamo), Kagoshima (Cape Sata), Nakanoshima, Amami-Oshima (Mt. Yuwandake), Okinawa (Yona), Ishigaki (Mt. Omotodake), and Taiwan (Penpuchi, Fenchihu, Kenting, Nanshanchi, Alishan).

Distribution : Japan (Shikoku, Kyushu, Tsushima, Ryukyus), Taiwan, and China (Fukien).

BiOLOGY : Unknown. 


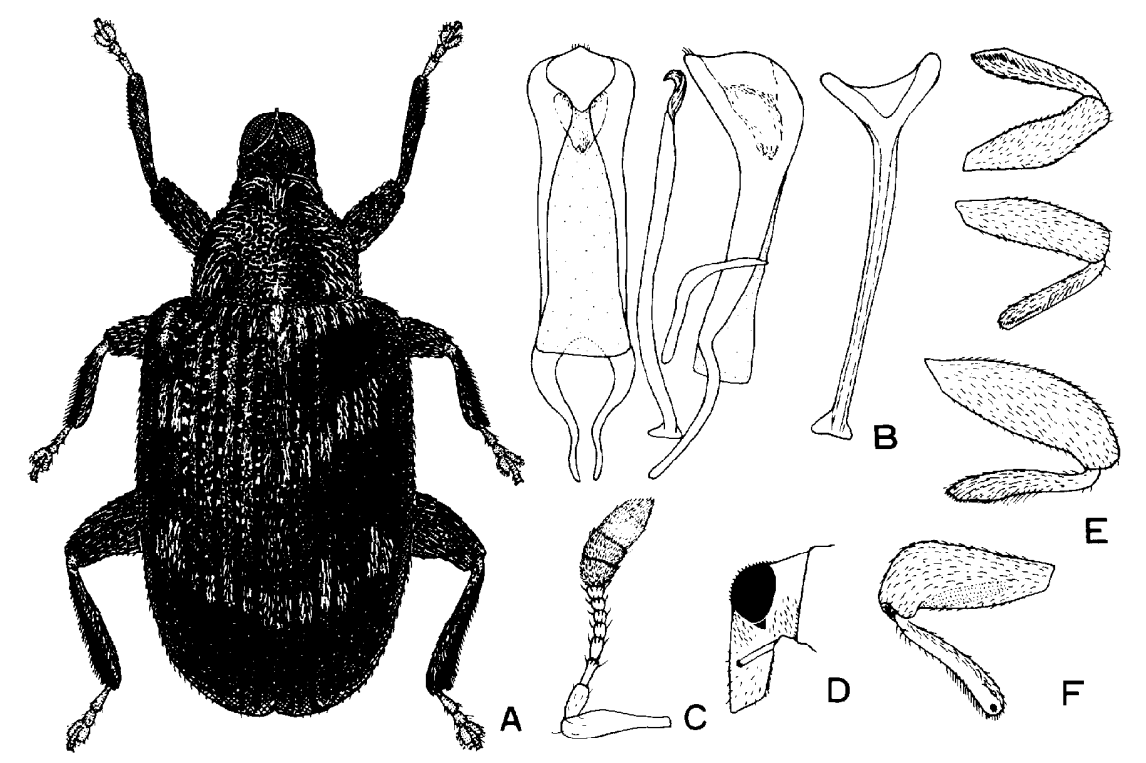

Fig. 11. Orchestoides decipiens Roelofs. A : Male. B : Aedeagus. C: Antenna. D: Head. E : Legs. F: Hind leg, showing the flat exterior surface of tibia. (After Morimoto, 1964)

\section{Orchestoides nipponicus Morimoto}

Orchestoides nipponicus Morimoto, 1964, Kontyû, 32 : 453 (Type-locality: Mt. Hiko ; Yamanashi, Kochi).-Morimoto, 1984, Col. Jap., IV: 296.

Specimens eXAmined: 12 exs. from Niigata (Kurokawa, Ooshima), Yamanashi (Amariyama), Wakayama (Mt. Gomadan), Kochi (Makiyama, Mt. Tebako), and Fukuoka (Mt. Hiko).

Distribution : Japan (Honshu, Shikoku, Kyushu).

BIOLOGY: Unknown.

This is very close to decipiens, but separable from it by the characters noted in the key. The basal band of elytra is usually interrupted by the first intervals, the antemedian and postmedian bands are less sinuate, the subapical band is usually separated by the first intervals, and all bands are formed of sparser greyish hairs than those in decipiens.

\section{Orchestoides shirozui Morimoto}

Orchestoides shirozui Morimoto, 1964, Kontyû, 32 : 452 (Type-locality : Mt. Omotodake ; Ishigaki, Iriomote). -Morimoto, 1984, Col. Jap., IV : 295, pl. 58, fig. 8.

SPECIMENS EXAMINED : 22 exs. from Kochi (Kuroson), Amami-Oshima (Mt. Yuwandake), Tokunoshima (Ohara), Okinawa (Yona), Ishigaki (Bannadake, Omotodake, Kaarayama), Iriomote (Ushikumori), and Taiwan (Wulai, Ilan, Nanshanchi). 
Distribution: Japan (Shikoku, Ryukyus) and Taiwan.

Biology : Unknown.

This species is easily recognized by the oval elytra with distinct postscutellar patch.

\section{Orchestoides maetai Morimoto}

Orchestoides maetai Morimoto, 1964, Kontyû, 32: 454, fig. 4 (Type-locality: Cape Sata; Okinawa). -Morimoto. 1984, Col. Jap., IV : 295, pl. 58, fig. 7.

SpecimEns examined: 5 exs. from Kagoshima (Cape Sata, Oodomari), and Okinawa (Izumi-Gogayama, Hijigawa, Mt. Yonahadake).

Distribution : Japan (Kyushu : Kagoshima, Okinawa).

BiologY : Unknown.

This peculiar species is easily distinguished by its slender body and characteristic markings on elytra.

\section{Orchestinus Morimoto}

Orchestinus Morimoto, 1964, Kontyû, 32 : 450 (Type-species : Orchestinus oculatus Morimoto, 1964, by original designation). -Morimoto, 1984, Col. Jap., IV : 295.

Very close to Orchestoides in having the similar rostrum, antennae, prosternum and legs, but separable from it by the following points : Forehead strongly prominent from the outline of head in consequence with the transverse depressions behind eyes and at the base of rostrum, interocular area triangularly dilated anteriorly, the narrowest area with two rows of hairs, and second ventrite as long as third at the middle.
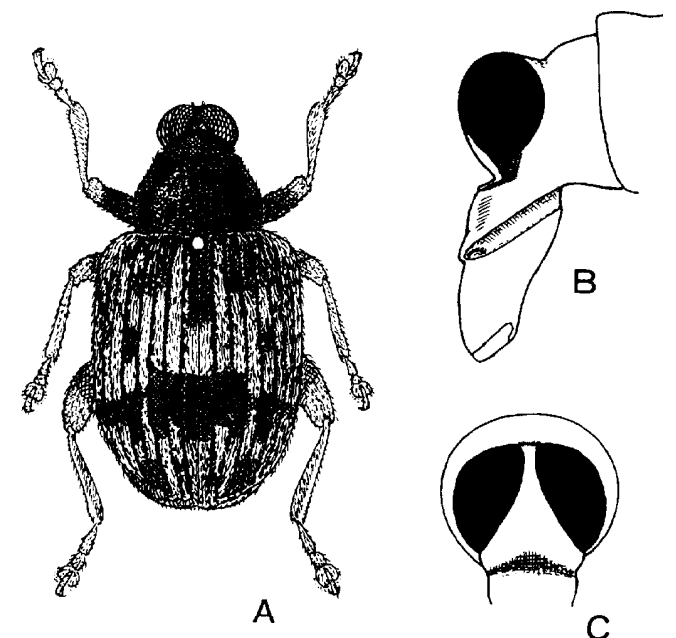

Fig. 12. Orchestinus oculatus Morimoto. A : Female. B : Female head. C : Forehead. (After Morimoto, 1964)

C 


\section{Orchestinus oculatus Morimoto}

Orchestinus oculatus Morimoto, 1964, Kontyû, $32: 450$, fig. 1 (Type-locality : Iriomote). -Morimoto, 1984, Col. Jap., IV : 295.

This species was described on a female from Ushikumori, Iriomote, and no additional specimen has been captured up to the present.

Distribution : Japan (Iriomote).

Rhynchaenus Clairville et Schellenberg

European species of the genus Rhynchaenus have often been separated into seven or eight subgenera, and three more subgenera have been described from the other part of the world. The subgenera are as enumerated below : (Type-species of each subgenus is written in the parentheses).

Alyctus Thomson, 1859. (rusci)

Anomorrhynchaenus Voss, 1962. (mus)

Euthoron Thomson, 1859. (fagi)

Hyporhynchaenus Voss, 1940. (lauraceae)

Isochnus Thomson, 1859. (populi)

Orchestes Illiger, 1798. (quercus)

Rhynchaenus Clairville and Schellenberg, 1798. (lonicerae)

Pseudorchestes Bedel, 1894. (pratensis)

Pseudendaeus Voss, 1959. (endaeoides)

Pseudorchestes Bedel, 1894. (pratensis)

Tachyerges Schoenherr, 1826. (salicis)

Threticus Thomson, 1859. (testaceus)

I have revised the subgeneric classification of the genus since the application of the European system to the Japanese species is inadequate in some species groups.

The diagnostic characters I have studied are as follows. Each character is coded in two or three states $(1,2,3)$ according to the supposed plesiomorphic to the apomorphic states.

A. Forehead between eyes.

$1:$ as wide as the apex of scape.

2: narrower than the scape.

3 : linear, with a row of scales or hairs at the narrowest portion.

B. Length of rostrum to the anterior margin of eye seen dorsally divided by maximum width in male.

$1:$ less than 5 .

2: more than 5 .

C. Dorsal contour of head and rostrum seen laterally. 1: even or slightly depressed at the base of rostrum.

2: distinctly depressed at the base of rostrum.

D. Funicle of antennae. 
1 : seven-segmented.

2: six-segmented.

E. Antennal insertion index. The distance between socket and the anterior margin of eye divided by the distance between the apex of clypeus and the anterior margin of eye seen laterally and measured in a straight line $x 100$.

1: $40-50$.

$2: 20-50$.

3 : less than 20 .

F. Scape of antennae.

1 : much longer than the first and second segments of funicle combined.

$2:$ much longer than the first, or about as long as the first and second combined.

3 : about as long as the first segment of funicle.

G. Club of antennae.

1 : much longer than the first and second of funicle combined.

2 : much longer than the first, or about as long as the first and second combined.

3 : about as long as the first segment of funicle.

H. Coxal cavities of prothorax.

1 : connate internally and the prosternal process distinctly concave between coxae.

2: narrowly separated by the linear prosternal process.

3: separated by the scaled or haired flat prosternal process.

I. Fore coxae.

1: contiguous.

2: narrowly separated in specimens with well expanding femora.

3: always and distinctly separated.

J. Erect setae on the side margins of pronotum.

1: absent.

2: present.

K. Tubercle or conical swelling of pronotum. Species with tubercles are distributed in the Oriental Region, including many undescribed species.

1: without swelling.

2 : with swelling or tubercle.

L. Longitudinal median sulcus on pronotum.

1 : absent.

2: shallow or indistinct.

3: well marked.

M. Erect setae on the side margins of elytra.

1 : absent.

2: present.

$\mathrm{N}$. White scales on scutellum.

1 : absent or not denser than those on elytra.

2: a little denser than those on elytra.

3 : dense in contrast to elytral scaling. 
0 . White scales on the side pieces of meso- and metathoraces.

1 : not denser than those on elytra.

2: distinctly denser than those on elytra and sternites.

P. Postscutellar white patch.

1: absent.

2: present.

Q. Scaling of elytra.

1: uniform, concolorous, immaculate, and fine.

2: maculate or variegated.

R. Subapical swellings on the declivity of elytra.

$1:$ indistinct.

2: distinct.

S. Fore and mid femora.

1: unarmed.

2 : armed each with a denticle with spine.

T. Length of hind femur divided by the maximum width.

1 : more than 3.0

$2: 2.6-3.0$.

3 : less than 2.6.

U. Denticles on the posterior margin of hind femur.

1 : absent.

2: indistinct.

3: present.

V. Long setae on the posterior margin of hind femur.

1 : absent.

2 : present, two to seven in number.

$\mathrm{W}$. Long spines on the denticles along the posterior margin of hind femur.

1 : absent.

2 : present, one to eight in number.

$\mathrm{X}$. Short spines on the denticles along the posterior margin of 'hind femur.

1 : absent.

2: present.

Y. Hind tibia.

$1:$ almost straight.

2: more or less curved.

Z. Carina on the outer face of flat surface along the interior edge of tibia.

1: absent.

2: present.

a. Long setae along the inner margin of the flat surface by the interior edge of tibia.

1: absent.

2: present.

b. Distance between mid coxae. 

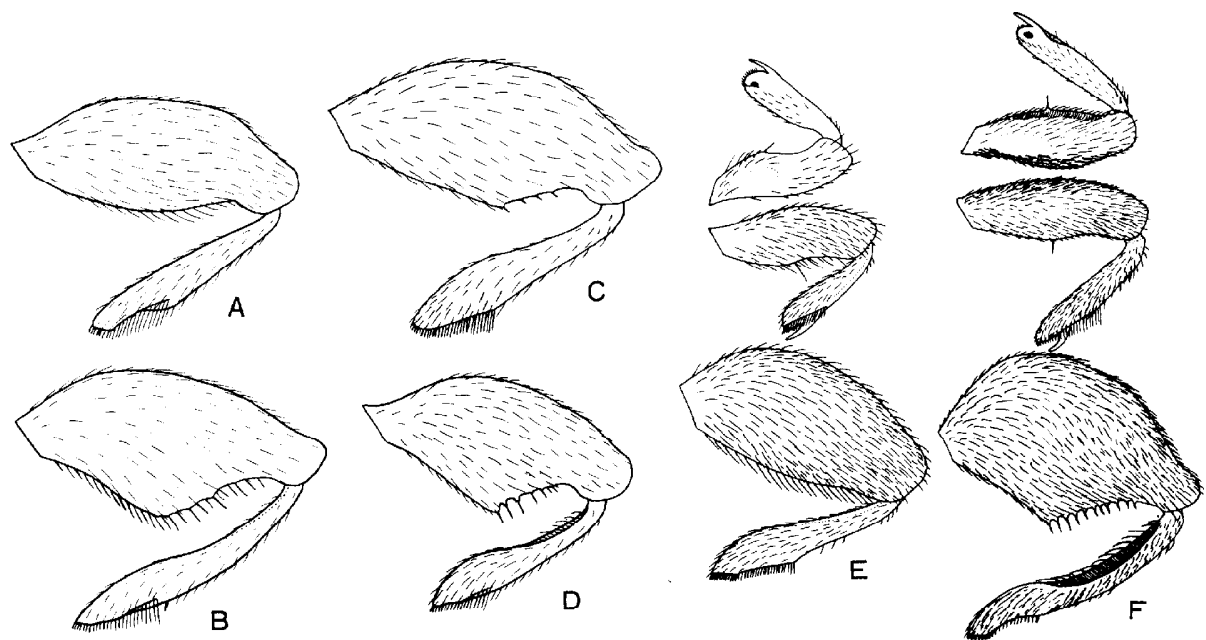

Fig. 13. A-D : Hind leg. E-F : Fore, mid and hind legs. A : Rhynchaenus (Alyctus) rusci (Herbst). $\mathrm{B}:$ Rhynchaenus (Pseudorchestes) pratensis (Germar). C: Rhynchaenus (Threticus) testaceus (Mueller). D : Rhynchaenus (Euthoron) fagi (Linnaeus) E: Rhynchaenus (Nomizo) kamiyai subg. et sp. nov. F: R hynchaenus (O rchestes) sanguinipes (Roelofs).

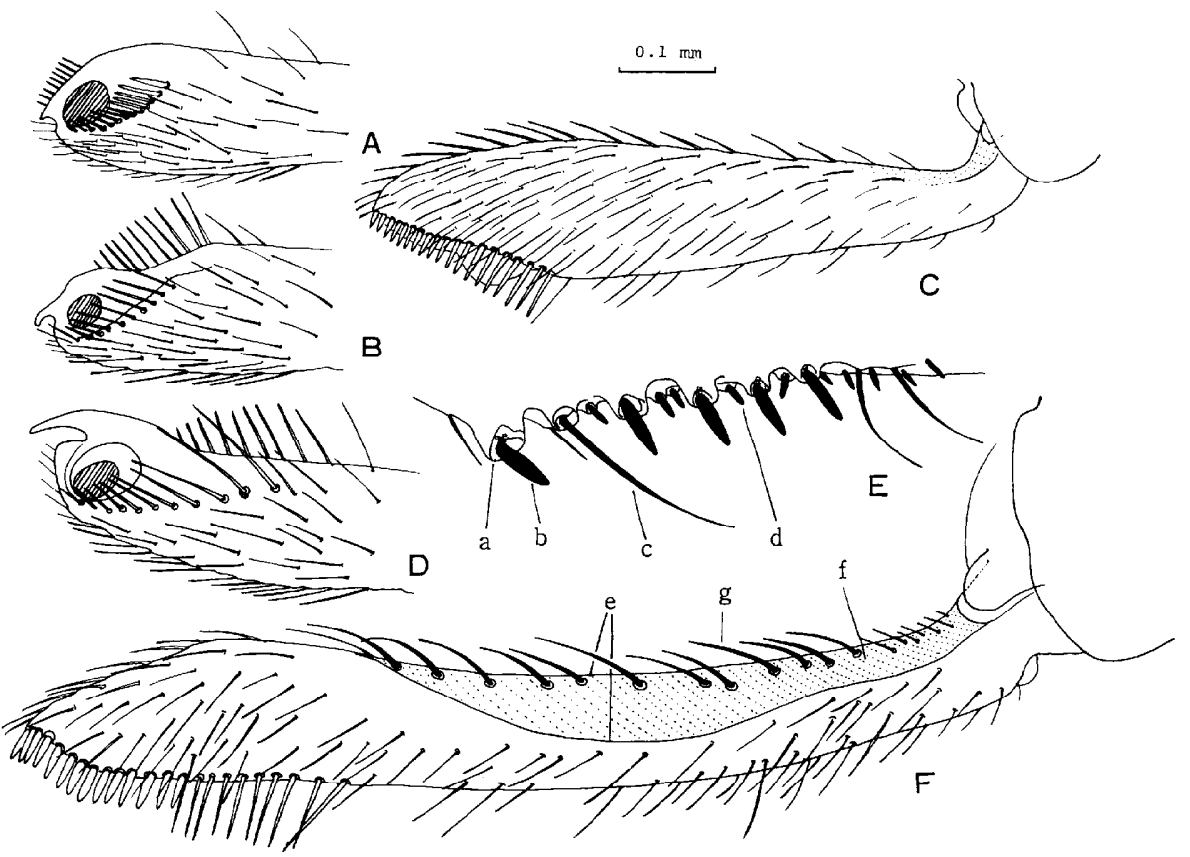

Fig. 14. Parts of legs. A-C : Rhynchaenus (Rhynchaenus) lonicerae (Herbst). D-F: Rhynchaenus (O rchestes) quercus (Linnaeus). A. D : Apex of fore tibia. B : Apex of mid tibia. C, F: Hind tibia. E : Posterior margin of hind femur, enlarged. (a : denticle. b : long spine. $c$ : long seta. $d$; short spine. e : carina. $\mathrm{f}$ : flat surface. $\mathrm{g}$ : long seta of flat surface) 


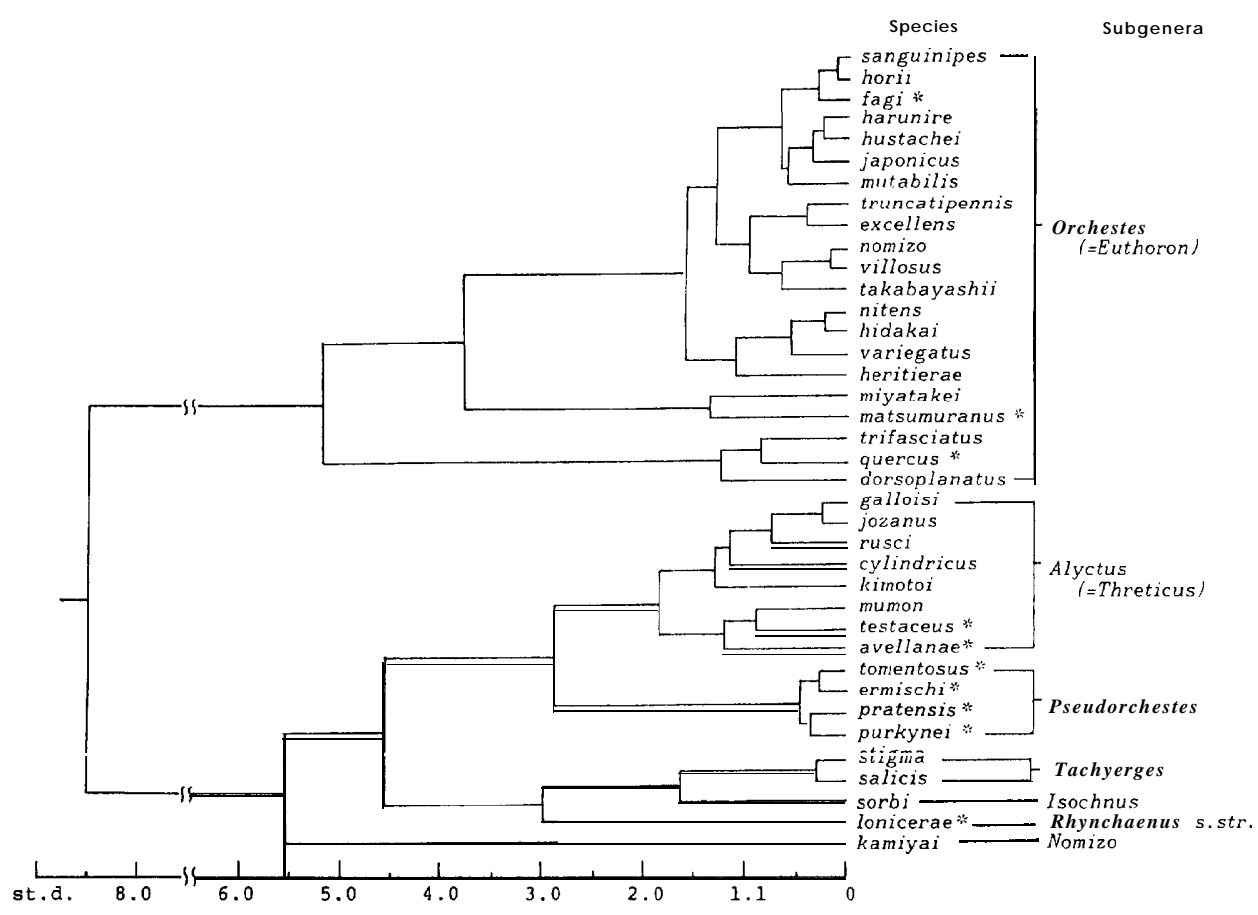

Fig. 15. A dendrogram of the genus Rhynchaenus resulted from cluster analysis by the flexible method $(\beta=-0.25)$. Asterisks indicate the species from Europe and Taiwan (matsumuranus).

1: much narrower than a coxa.

$2:$ as wide as a coxa.

c. Uncus of fore and mid tibiae.

1: sickle-shaped, originated from the dorsal edge a little behind the apex.

2: small, originated below the middle of apical margin.

The analyses of the original $\mathrm{n}$ (character) $\mathbf{x} t$ (taxa) matrix by the Ward method, furthest neighbour method, group average method and flexible method resulted in obtaining dendrograms. The dendrograms are similar in the main points and the example by the flexible method is shown in Fig. 15.

The phylogeny of the subgenera is inferred also from the view points of the morphocline in the following characters :

1. Hind femora have a tendency to getting larger and thicker than the anteriors in accordance with the adaptation to jumping, and the posterior margin has a tendency to arm with denticles, spines and/or long setae accompanying triangular expansion posteriad.

2. In accordance with the development of hind femora, the hind tibiae have a tendency to be sinuate and excised the interior edge into a flat surface bearing a row of inflexed long setae. 
3. Another morphocline is observed on the vesture. They are simple and sparse in the plesiomorphic condition, and becoming denser or variegated, and the pronotum and elytra are fringed with erect setae in the apomorphic condition.

4. Swelling or tubercle on the pronotum and the subapical swellings on elytra are developed in the apomorphic condition. A sign of these characters is observed in quercus, and typical species are distributed in the Oriental Region.

From these morphoclines, the Rhynchaenus can be classified into three principal grades.

Grade I. Hind femora simple, unarmed ; hind tibiae simple, straight. Pronotum and elytra without erect setae

...........................Isochnus, Rhynchaenus, Tachyerges and Nomizo

Grade II. Hind femora more or less swollen, with distinct or indistinct denticles and with or without spines ; hind tibiae simple, straight. Pronotum and elytra often with a few erect setae $\cdots \cdot$. Alyctus, Threticus and Pseudorchestes

Grade III. Hind femora swollen, with denticles, long and short spines, and long setae ; hind tibiae curved, with flat surface internally bordered with sharp carinae and with a row of long setae. Pronotum and elytra very often with erect set ae

Orchestes and Euthoron

The subgenera Isochnus, Tachyerges and Rhynchaenus (lonicerae) are close to each other in having many plesiomorphic characters. Rhynchaenus s. str. containing one species, lonicerae, is unique in this genus by the reduced unci of fore and mid tibiae.

New subgenus Nomizo is proposed for kamiyai. This may be regarded as an intermediate group between Orchestoides and Rhynchaenus in having the such common characters to Orchestoides, Orchestinus and Imachra that the prosternal process flat and distinctly separating fore coxal cavities, mesosternal process as wide as a coxa, and the antennal scrobes on rostrum not touching eyes.

The subgenus Pseudorchestes is well characterized by Dieckmann (1958) as follows : Forehead between eyes relatively wider. Rostrum longer, more than 5 times as long as wide. Antennal insertion index less than 20. Scape of antennae about as long as first segment of funicle, club at most as long as first and second segments of funicle combined. Hind femora often with indistinct denticles and long spines, but not with long setae and short spines. Hind tibiae not flattened internally, without carinae.

The subgenus Alyctus is an intermediate between the above mentioned subgenera and Orchestes. This is grouped into two by the structures of hind legs. Threticus is only separable from Alyctus in the scaly coloration and included in the latter in this study.

The subgenus Orchestes treated here contains Euthoron. Euthoron fagi is very close to sanguinipes, horii and some other Japanese species in the concolorous vesture. Euthoron has been keyed by many European taxonomists in the group without erect setae on pronotum and elytra, but fagi has erect setae on pronotum and elytra. This subgenus is considerably heterogeneous at present as seen in Fig. 15, and need the revision including many undescribed species from the Oriental Region. 


\section{Key to Palaearctic subgenera}

1(2): Fore coxal cavities separated by flat prosternal process. Hind femora unarmed. Mesosternal process as wide as a coxa. Antennal scrobes directing posteriorly below eyes Nomizo subg. nov.

2(1): Fore coxal cavities separated by linear prosternal process, which often concave between coxae. Mesosternal process narrower than a coxa. Antennal scrobes directing posteriorly to the lower part of eyes.

3(12): Hind tibiae simple, without flat surface internally, without erect long setae along internal margin.

4(5): Antenna1 scape as long as or shorter than the first of funicle. Rostrum more than 5 times as long as wide. Antennal insertion index less than 20. Eyes widely separated Pseudorchestes

5(4): Antennal scape much longer than the first of funicle. Rostrum often less than 5 times as long as wide. Antennal insertion index more than 20. Forehead between eyes narrower.

6(7): Fore and mid tibiae each witr a small uncus originated from the middle of apical margin (Fig. 14, A-B) …............................................ Rhynchaenus

s. str.

7(6): Fore and mid tibiae each with a sickle-shaped large uncus originated from the dorsal edge a little behind the apex. (Fig. 14, D)

8(11): Scutellum and lateral pieces of meso- and metathoraces densely covered with white scales. Hind femora slender, more than 2.8 times as long as wide. Pronotum and elytra without erect setae at sides.

9(10): Hind femora slender, slightly thicker than the anteriors, more than 3.5 times as long as wide. Dorsal surface sparsely clothed with fine hairs. Small species......... Isochnus

10(9): Hind femora distinctly thicker than the anteriors, less than three times as long as wide. Antennal funicle with seven segments

Tachyerges

11(8): Scutellum and lateral pieces of meso- and metathoraces not densely covered with white scales. Hind femora often less than 2.8 times as long as wide, often with denticles and/or spines along hind margin. Pronotum often with a few erect setae at sides ….........................................................

12(3): Hind tibiae curved, with carinae along the both edges of flat surface along the internal margin, and with a row of long setae along the inner face of flat surface. Hind femora armed with denticles, spines and setae. Pronotum and elytra often with erect setae at sides

Orchestes

(=Euthoron)

\section{Nomizo subgenus nov.}

Type-species :Rhynchaenus kamiyai sp. nov.

Antennal scape much longer than first segment of funicle, funicle six-segmented, third segment of club shorter than first and second segments of club combined. Fore and mid femora armed each with a spine. Hind femora much thicker than the anteriors, unarmed. Fore and mid tibiae uncinate; hind tibiae unarmed at tip, simple. Fore coxal cavities separated by the flat prosternal process. Pronotum broadest at the base. Scutellum distinct. 


\section{Rhynchaenus kamiyai sp. nov.}

Black, antennae and tarsi reddish brown, tibiae and lower part of femora often reddish brown ; derm clothed with recumbent dark brown hairs, whitish hairs scattered sparsely on pronotum and elytra, scutellum and head around eyes rather closely covered with whitish hairs. Lateral and ventral surfaces of thorax sparsely clothed with white hairs. Venter sparsely clothed with fine brownish hairs, often the lateral area bearing whitish short hairs.

Head with dense punctures, with a fine median carina; forehead linear. Rostrum nearly parallel-sided, gently curved, as long as pronotum, 3.0 (male) or 4.0 (female) times as long as wide, punctate at side and basal area behind scrobes. Antennae with scape shorter than first and second of funicle combined, antenna1 insertion index 30 (male) or 25(female).

Pronotum subtrapezoidal, broadest at the base, anterior margin truncate and half the width of the posterior margin, disk very closely punctate. Scutellum a little longer than wide. Elytra parallel-sided to the middle, 5/4 times as long as wide, intervals flat, coriaceous, slightly broader than stria, striae clearly sculptured, punctures deep and sharp.

Hind femora simple, 2.2 times as long as wide.

Length : 2.2-2.4 mm.

Holotype male (Type No.2454, Kyushu Univ.), and 13 paratypes : Nagasaki City, 31. vii \& 4. viii. 1957, H. Kamiya leg.

Distribution: Japan (Nagasaki).
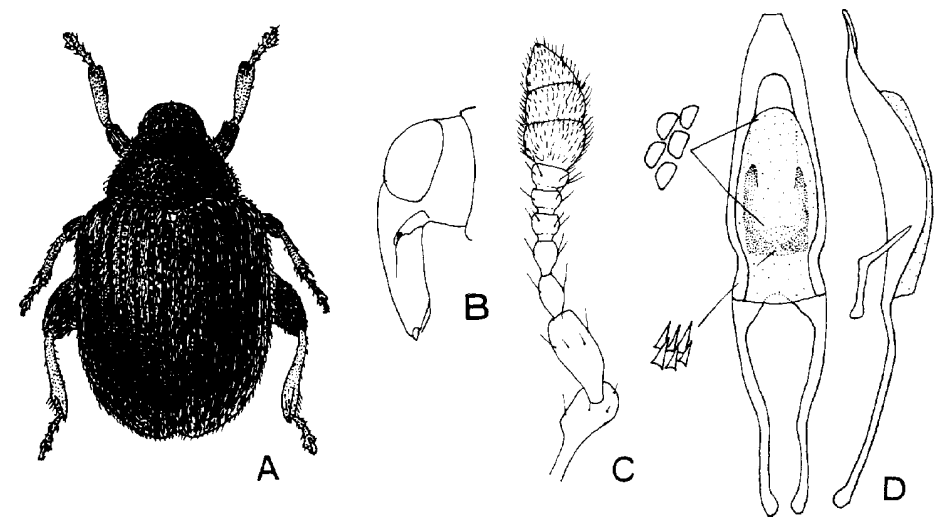

Fig. 16. Rhynchaenus (Nomizo) kamiyai sp. nov. A: Male. B : Male head. C: Antenna. D : Penis. 
Subgenus Isochnus Thomson, 1959

\section{Rhynchaenus sorbisp. nov.}

Oblong, weakly convex. Black, antennae and legs reddish brown, rarely hind femora slightly infuscate. Derm sparsely clothed with greyish brown pubescence ; scutellum, lateral pieces of meso- and metathoraces, and lateral margin of metasternum closely covered with white scales.

Head reticulately punctate, forehead between eyes narrower than the apex of scape. Rostrum 2.2 (male) or 3.0 (female) times as long as wide, evenly curved, glossy, sparsely with fine punctures, which being a little denser at sides. Antennae inserted in basal third (male) or in the middle (female) of rostrum, funicle six-segmented.

Pronotum $3 / 4$ times as long as wide, subapical constriction weak, anterior margin $3 / 4$ the width of the posterior, disk closely punctate, punctures smaller and closer towards the posterior and side margins.

Scutellum subtriangular, broader than long.

Elytra oblong-oval, broadest a little before the middle, the sides gently rounded, coriaceous at the base, intervals subconvex, with a row of pubescence.

Hind femora scarcely thicker than the anteriors, 3.7 times as long as wide. Tibiae simple.

Fore coxae and coxal cavities contiguous. Pro-and mesosterna, marginal areas of metasternum and abdomen closely punctate.

Length :1.8-2.0 mm.

Holotype male (Type No. 2455, Kyushu Univ.) and 24 paratypes : Yukomanbetsu, Mt. Daisetsu, Hokkaido, 26. vii. 1955, K. Morimoto leg.

BIOLOgy : The adults were captured on Sorbus commixta (Nanakamado in Japanese).

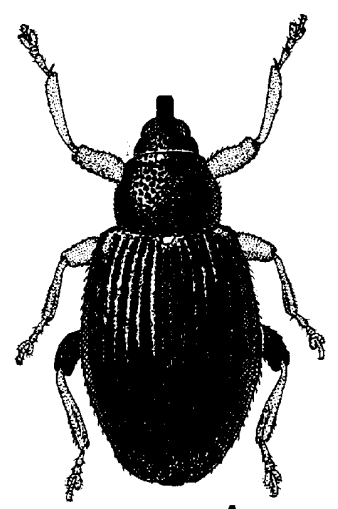

A

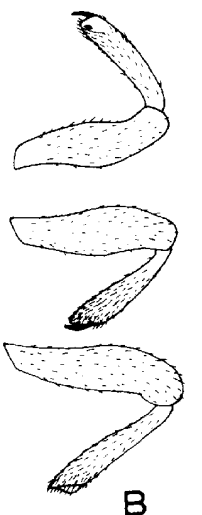

B

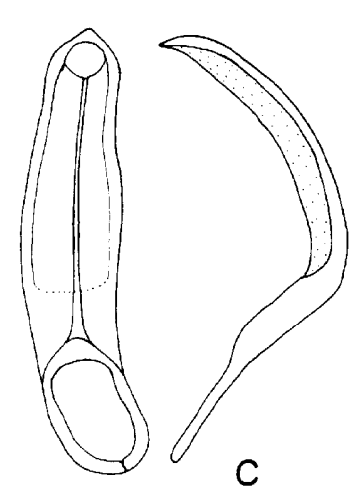
A: Male. B : Legs. C : Penis.

Fig. 17. Rhynchaenus (Isochnus) sorbi sp. nov .

A 
This new species is close to populi and angustifrons, but can be separable from the known species of the subgenus by the following key. (arcticus Korotyaev, 1976, from Wrangel Is. is not included)

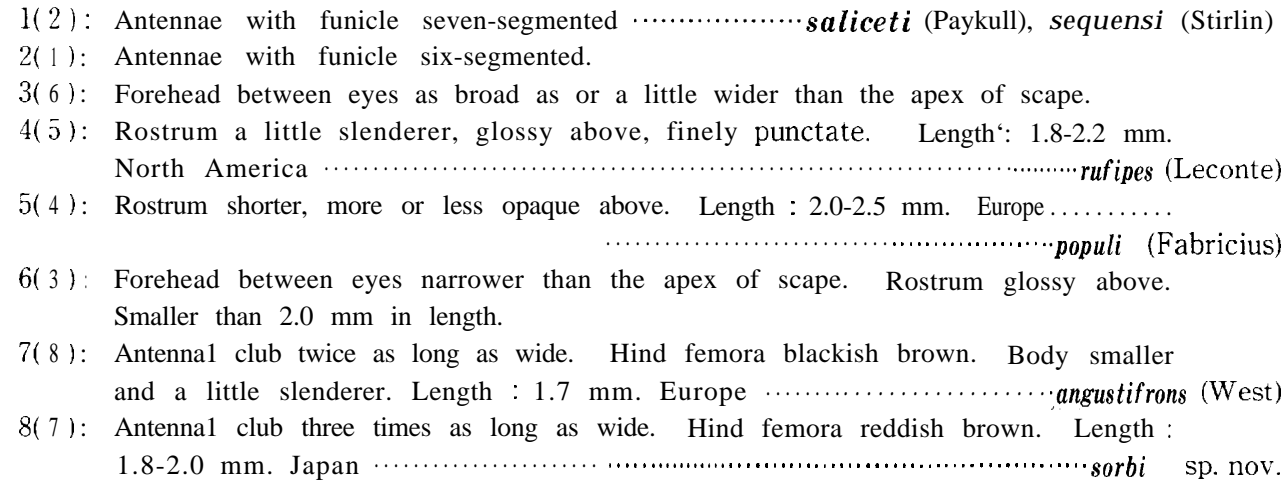

\section{Sugbenus Tachyerges Schoenherr, 1826}

KeY to SPECIES

1(2): Elytra entirely black with blackish pubescence. Scutellum densely covered with

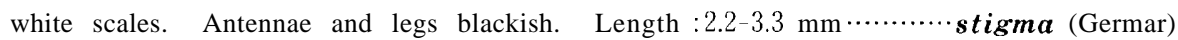

2(1): Elytra with whitish scaly bands.

$3(4)$ : Anterior band of elytra rhomboidal, extending anteriorly to the base and posteriorly to the posterior band on first and second intervals; pronotum with whitish patch

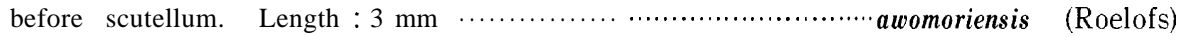

4(3): Elytra with two bands, first interval between anterior band and scutellum filled with

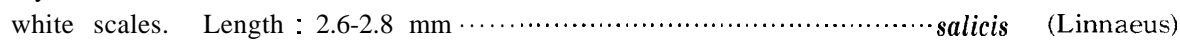

\section{Rhynchaenus stigma (Germar)}

Salius stigma Germar, 1805, Mag. Ent., IV : 334.

Tachyerges stigma : Stephens, 1831, I11. Brit. Ent. Mandib., IV : 67.

Orchestes (Tachyerges) stigma : Schoenherr, 1839, Gen. Sp. Curc., III : $504 . \quad$-Kôno, 1930, Ins. Mats., V : 29 (Sakhalin, Hokkaido, Honshu).

Rhynchaenus (Tachyerges) stigma : Klima, 1935, Col. Cat., 145, Rhynchaeninae : 30. -Ter-Minassian, 1953, Ent. Oboz., XXX111:318. -Morimoto, 1962, Sci. Bull. Fac. Agr., Kyushu Univ., 19 : 187 (Hokkaido, Honshu, Sakhalin). - Tempere, 1982, Nouv. Rev. Ent., XII : 249. -Morimoto, 1984, Col. Cap., IV : 296. pl. 58. fig. 11.

Black, claws brown, antennae often brownish black ; dorsal surface thinly covered with blackish pubescence ; legs and underside sparsely with fine greyish hairs, which are slightly denser on pro- and mesosterna and lateral pieces of meso- and metathoraces; scutellum densely covered with white scales.

Forehead between eyes linear. Rostrum long, 4.25 (male) or 4.50 (female) times as long as wide, slightly curved. Antennae inserted in the middle (male) or behind the middle (female) of rostrum, scape as long as club and as long as basal four segments 

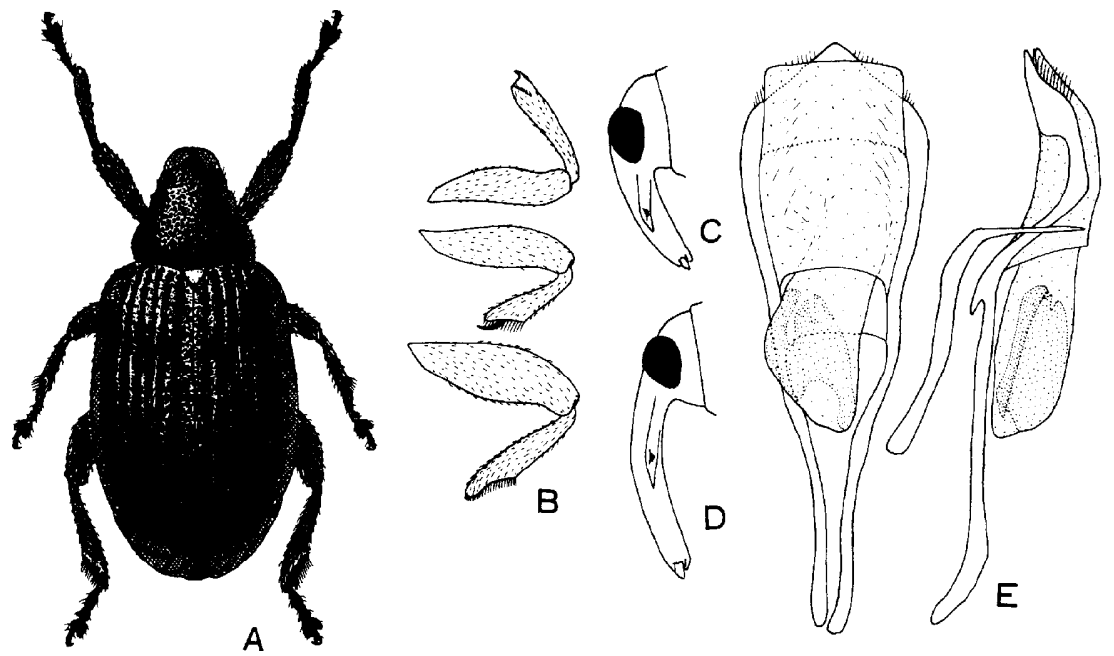

Fig. 18. Rhynchaenus (Tachyerges) stigma (Germar) A : Male. B : Legs. C : Male head. D : Female head. E: Penis.

of funicle combined.

Pronotum and elytra without erect setae at sides.

Hind femora slightly thicker than the anteriors, 2.8 times as long as wide, simple. Fore and mid femora unarmed. Tibiae straight, simple.

Length : 2.7-3.3 $\mathrm{mm}$.

Spectmens examined : 35 exs. from Hokkaido (Ashoro, Lake Kuccharo, Mt. Daisetsu, Nukabira, Bifuka), Nagano (Shirahone), and Tottori (Mt. Daisen).

Distribution : Japan (Hokkaido, Honshu), Siberia, and Europe.

Biology : The adults were captured on Salix spp.

\section{Rhynchaenus salicis (Linnaeus)}

Curculio Salicis Linnaeus, 1758, Syst. Nat., ed. X : 381.

Orchestes (Tachyerges) salicis : Schoenherr, Gen. Sp. Cm-c., VII(2) : 379. -Kôno, 1930, Ins. Mats., V : 29 (Sachalin).

Rhynchaenus (Tachyerges) salicis : Klima, 1935, Col. Cat., 145, Rhynchaeniniae : 25. -Ter-Minassian, 1953, Ent. Oboz., XXX111 : 319. -Morimoto, 1962, Sci. Bull. Fac. Agr., Kyushu Univ., $19: 187$

(Hokkaido, Honshu, Sakhalin, Kuril Isls.). -Morimoto, 1984, Col. Jap., IV : 296, pl. 58, fig. 19.

Black, antennae excepting club and claws dark brown; anterior band on elytra often yellowish on first and second intervals, more or less produced posteriorly on second interval, posterior band concave ; scaling on legs and underside as in stigma.

Forehead between eyes linear. Rostrum about 2.7 times as long as wide in both sexes. Antennae inserted in (male) or just behind (female) the middle of rostrum, scape as long as club and as long as three basal segments of funicle combined.

Pronotum and elytra without erect setae at sides. 
Femora as in stigma, hind femora 2.8 times as long as wide. Fore coxall cavities cont iguous.

Length : 2.6-2.8 $\mathrm{mm}$.

Specimens eXAmined : 14 exs. from Hokkaido (Nukabira, Yukomanbetsu), Akita (Kuromori-Pass), Niigata (Shiroike, Renge Spa, Mt. Myoko, Sasagamine), Gumma (Mt. Tanigawadake, Minakami), and Nagano (Shimashimadani).

Distribution: Japan (Hokkaido, Honshu), Sakhalin, Kuril Isls., Siberia, and Europe.

Biology: The adults were captured on Salix spp.

\section{Rhynchaenus awomoriensis (Roelofs)}

Orchestes (Tachyerges) awomoriensis Roelofs, 1874, Ann. Soc. Ent. Belg., XVII : $167 . \quad$-Faust, 1882, Deut. Ent. Zeit., XXVI : 282, nota.-Kôno, 1930, Ins. Mats., V : 29.

Rhynchaenus (Tachyerges) awomoriensis : Klima, 1935, Col. Cat., 145, Rhynchaeninae : $11 . \quad-$ Ter-

Minassian, 1953, Ent. Oboz., XXXIII : 323. -Morimoto, 1962, Sci. Bull. Fac. Agr., Kyushu Univ.,

19: 185. -Morimoto, 1984, Col. Jap., IV : 297.

I have examined so far only two specimens, one in the collection of Hokkaido University and the holotype in the British Museum (Natural History). The drawing of fig. 19,E, was made on the holotype.

Distribution : Japan (Honshu).

Subgenus Alyctus Thomson, 1859

\section{KEY TO SEPECIES}

1(4): Elytra and pronotum immaculate, at most with indistinct postscutellar patch. Hind femora with three to five denticles and four to five long setae, 2.67-2.89 times as long
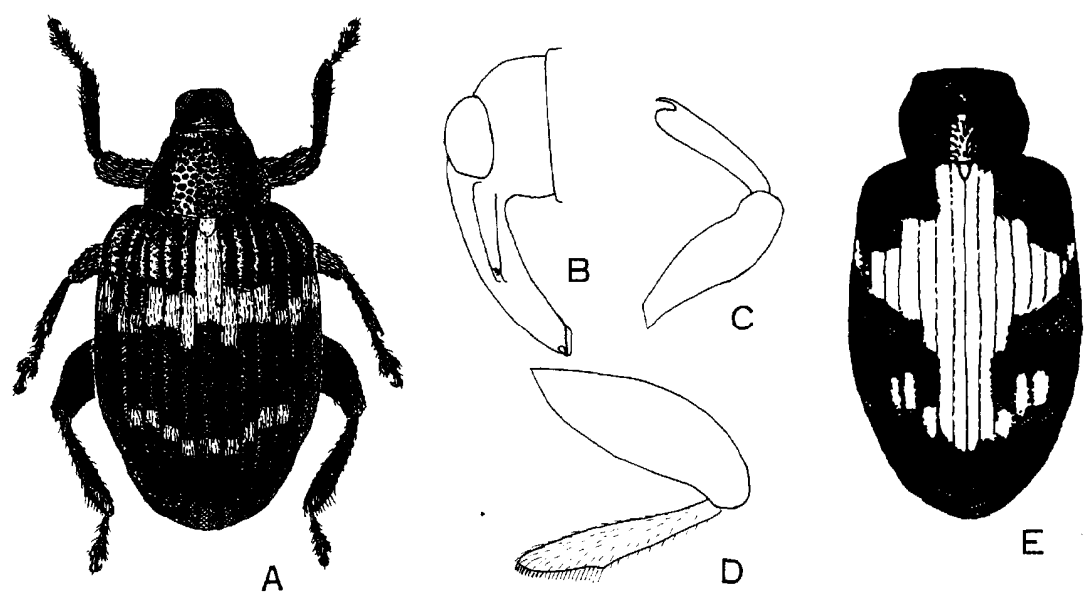

Fig. 19. A-D: Rhynchaenus (Tachyerges) salicis (Linnaeus). A : Male. B : Male head. C : Fore leg. D : Hind leg. E: Rhynchaenus (Tachyerges) awomoriensis (Roelofs). 
as wide.

2(3): Forehead between eyes as wide as apex of scape. Fore and mid femora unarmed. Black, claws brown, scape dark brown. Elytra 1.6 times as long as wide. Length : 2.8-3.4 mm n......................................................

3(2): Forehead between eyes linear, much narrower than apex of scape. Fore and mid femora armed with spine. Black, antennae and tarsi reddish brown. Elytra 1.4

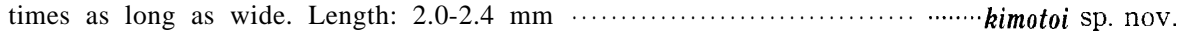

4(1) : Elytra and pronotum maculate with greyish to whitish hairs. Hind femora 2.31-2.52 times as long as wide, with indistinct denticles or unarmed, and at most with one or two long spines.

5( 6): Fore and mid femora unarmed. Hind femora unarmed, without long setae and spines along the hind margin. Forehead between eyes narrower than apex of scape. Elytra with distinct postscutellar white patch and two bands. Length : 2.6-2.9

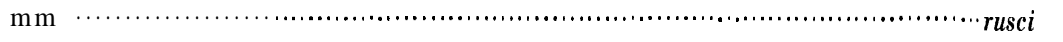

6(5): Fore and mid femora armed with spine. Hind femora with indistinct denticles or unarmed and one or two long spines along the hind margin. Forehead between eyes linear.

7(8): Elytra slender, subparallel-sided, 1.5 times as long as wide and 1.4 times as wide as pronotum. Pronotum 0.75 times as long as wide. Hind femora each with two long spines, Dorsal surface mottled with greyish hairs. Length: $2.0-2.4 \mathrm{~mm}$

cylindricus sp. nov.

8(7): Elytra oval, 1.2-1.4 times as long as wide, and about 1.8 times as wide as pronotum. Pronotum 0.5-0.6 times as long as wide. Hind femora each with one long spine. Elytra with bare black space between fourth striae behind the middle.

9(10): Hairs yellowish grey to golden grey, brilliant under certain light. Pronotum at most with one seta at hind angle. Forehead between eyes closest at posterior $1 / 3$, then

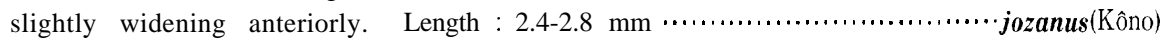

10(9): Hairs greyish and greyish brown, pronotum with greyish patch on each side at hind angle, elytra with greyish transverse band along the hind margin of postmedian bare area. Pronotum with a few erect setae at sides. Forehead between eyes linear. Length : 2.5-2.8 $\mathrm{mm}$

galloisi (Kôno)

\section{Rhynchaenus rusci (Herbst)}

Curculiorusci Herbst, 1795, Natursyst. Ins., Käfer, VI : 424.

Orchestes rusci : Schoenherr. 1836. Gen. Sọ. Curc., III : 501. -Kôno, 1930, Ins. Mats., V : 28 (Sakhalin).

Rhynchaenus (Alyctus) rusci: Klima, 1935, Col. Cat., 145, Rhynchaeninae : 24. -Ter-Minassian, 1953, Ent. Oboz., XXX111 : 315. -Voss, 1953, Ent. Blätt., XLIX : 66 (China). - Voss, 1958, Decheniana, Beihefte 5 : 107 (China). -Morimoto, 1958, Kontyû, 26: 186 (Hokkaido). -Morimoto, 1962, Sci. Bull. Fac. Agr., Kyushu Univ., 19 : 187. -Morimoto, 1984, Col. Jap., IV : 296, pl. 58, fig. 24.

Black, antennae and tarsi brownish ; pronotum with white patch on each side, elytra with whitish postscutellar patch and two transverse bands, underside with greyish to white hairs, which are a little denser on head around eyes, pro- and mesosterna, and side pieces of meso- and metathoraces.

Forehead between eyes narrow and dilated anteriorly. Rostrum 3.25 (male) or 3.62 (female) times as long as wide. Antennae with scape shorter than first and second of funicle combined, club as long as first and second of funicle combined.

Pronotum and elytra without erect setae at sides. 

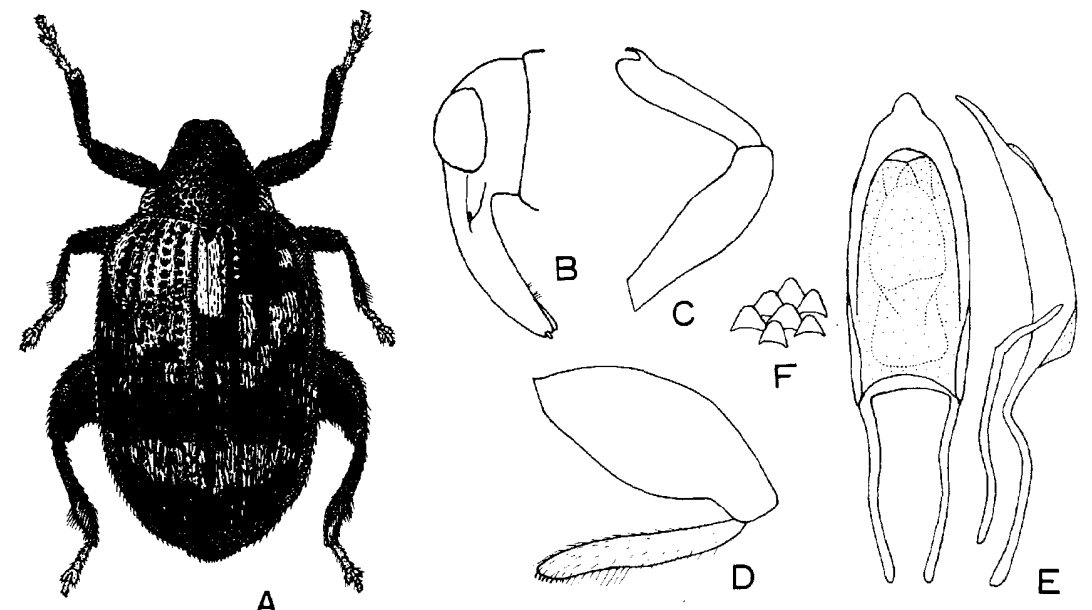

Fig. 20. Rhynchaenus (Alyctus) rusci (Herbst) A : Male. B: Male head. C : Fore leg. D : Hind leg. E: Penis. $F$ : Asperities of internal sac, enlarged.

Anterior femora unarmed. Hind femora evenly swollen, posterior margin not angulate but evenly curved, 2.44 times as long as wide. Hind tibiae not curved.

Length : 2.6-2.9 $\mathrm{mm}$.

SPeCimens examtned : 6 exs. from Nibushi, Hokkaido, 17. vii. 1955, K. Morimoto leg.

Distribution : Japan (Hokkaido), Kuril Isls., Kamchatka to Europe.

Biology : The adults were captured on the leaves of Betula platyphylla var. japonica (Shirakanba in Japanese).

\section{Rhynchaenus cylindricus sp. nov.}

Black, antennae, tarsi, apices of tibiae and apex of rostrum reddish brown to dark brown ; dorsal surface variegated with greyish hairs, head evenly covered with greyish hairs leaving a median bare line, pronotum with greyish hairs on side and posterior margins and on a line just behind subapical constriction, the hairs forming also oblique band from the side margin behind the middle to the middle of the basal margin ; scutellum with a few greyish hairs ; elytra with the following greyish patches, first interval with short stripe on basal $1 / 4$, second and third intervals with basal patch, median and postmedian ill-defined bands formed of small patches, and apical band, greyish hairs absent or very few on the oblique area between humeri and suture $1 / 4$ from the base, each stria with a row of greyish hairs ; prosternum, fore coxae, femora, lateral pieces of meso- and metathoraces, and sides of third to fifth ventrites clothed with similar hairs, which are dense on mesepimera, the remaining area of sternites and ventrites with sparse fine greyish hairs.

Head with dense punctures, coriaceous, forehead between eyes linear. Rostrum 

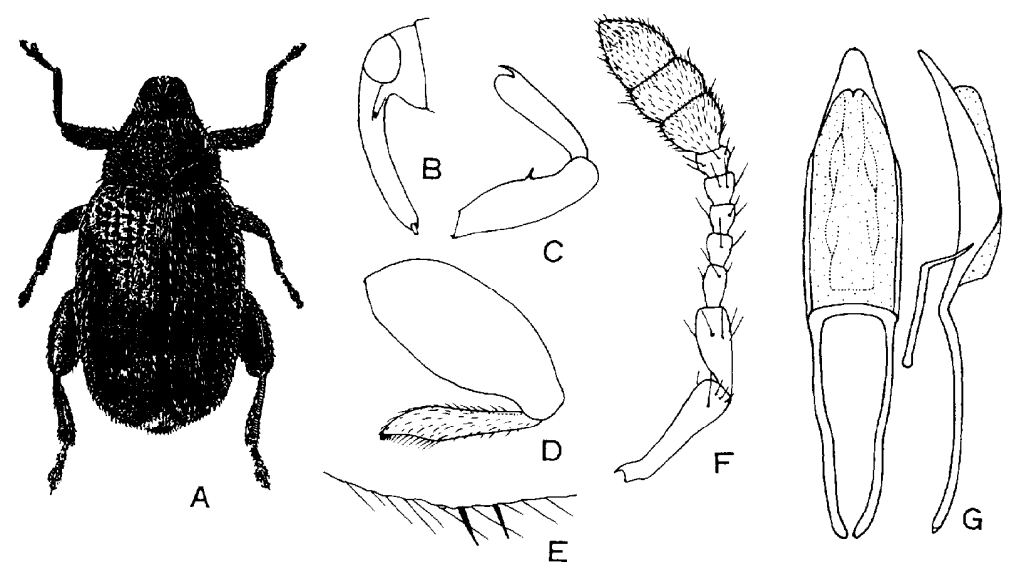

Fig. 21. Rhynchaenus (Alyctus) cylindricus sp. nov. A : Male. B : Male head. C : Fore leg. D : Hind leg. E : Posterior margin of hind femur, enlarged. F : Antenna. G : Penis.

long, 5.0 (male) or 5.6 (female) times as long as wide, shiny, dorsal area evenly convex and impunctate, lateral area with three rows of punctures, of which the dorsal one hairy above antennal scrobe, the median one extending distally from antennal socket. Antennae with scape shorter than first and second of funicle combined, club as long as basal three segments of funicle combined, antennal insertion index 19.2 (male) or 23.0 (female).

Prothorax $3 / 4$ times as long as wide, widest at base, rapidly narrowing in front with moderate curve, very shallowly constricted near the apex, the constriction continued across the disk, disk with dense punctures and coriaceous, without median sulcus.

Elytra 1.5 times as long as wide, sides subparallel, intervals much wider than striae, rugulose, coriaceous, subapical swellings absent.

Anterior four femora each armed with a spine. Hind femora 2.3 times as long as wide, posterior margin simply curved, with two spines. Hind tibiae straight, simple, tarsal groove ascended upwards to $1 / 3$ from apex.

Fore coxal cavities contiguous. First and second ventrites shiny, punctate, finely and longitudinally strigulate at sides, third and fourth ventrites excepting basal margins and fifth ventrite with small punctures and finely coriaceous.

Length : 2.0-2.4 mm.

Holotype male (Type No. 2456, Kyushu Univ.), Mt. Yahirodake, Sasebo City, Nagasaki Pref., 18. iv. 1983, J. Okuma leg.

Paratypes : Same data as holotype, 100 exs. Kamuri, Chikugo, Fukuoka Pref., 2 males, 23. viii. 1939, N. Gyotoku leg. Miyazaki City, one male and two females, 21. vii. 1953, T. Yoshida leg. Udo, Nichinan City, Miyazaki Pref., one male and one female, 11. vi. 1972, A. Nagai leg.

Distribution : Japan (Kyushu : Nagasaki and Miyazaki).

Biology: Mr. Okuma collected many larvae and pupae from the midrib of Pasania 
edulis (Matebashii in Japanese). The larvae feed on only the inside of midrib.

This new species is similar to parvidens Voss, 1958, from Fukien, China, but the latter has "kammzahnartige Bewehrung der Hinterschenkel".

\section{Rhynchaenus galloisi (Kôno)}

Orchestes galloisi Kôno, 1930, Ins. Mats., V : 28 (Tokio, Ins. Hachijo).

Rhynchaenus Galloisi: Klima, 1935, Col. Cat., 145, Rhynchaeninae : 15.

Rhynchaenus galloisi : Ter-Minassian, 1953, Ent. Oboz., XXX111 : $315 . \quad$ - Voss, 1958, Decheniana,

Beihefte 5 : 107 (China). -Morimoto, 1962, Sci. Bull. Fac. Agr., Kyushu Univ., 19 : 18 (Hokkaido,

Honshu, Shikoku, Kyushu, China). -Nakane, 1963, Icon. Ins. Jap. col. nat. ed., II : 378, pl. 189, fig. 14. - Morimoto, 1984, Col. Jap., IV : 296, pl. 58, fig. '22.

Black, antennae and tarsi reddish brown, tibiae often dark brown; dorsal surface mottled with greyish, greyish brown, and fine blackish hairs ; pronotum with greyish brown hairs, with white patch on each hind angle ; scutellum with sparse blackish fine hairs ; elytra mottled as fig. '22, A, visibly bare and blackish areas on second to sixth intervals before the middle, on the middle of first interval, and on second to fourth intervals behind the middle provided with blackish fine hairs, whitish hairs abundant and forming postscutellar indistinct patch and transverse band along the hind margin of the posterior bare area, greyish brown hairs often faded to greyish in timeworn specimens ; fore coxae, femora and lateral pieces of meso- and metathoraces with greyish hairs, mesepimera with white hairs at dorsal area, sternites and ventrites with fine sparse greyish hairs.

Forehead between eyes linear. Rostrum 4.2 times as long as wide in both sexes, dorsal area bare, with fine median sulcus between scrobes, punctate and hairy at sides. Antennae with scape slightly longer than first of funicle, club as long as first and second of funicle combined, antennal insertion index 24 in both sexes.

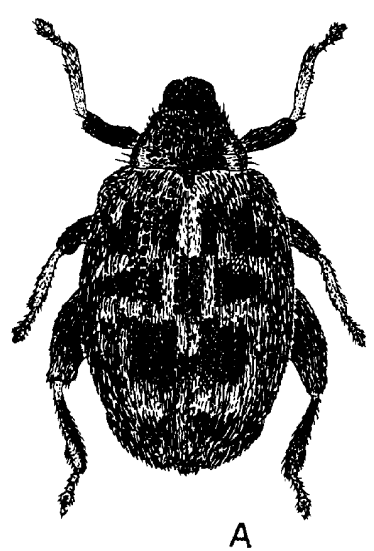

A

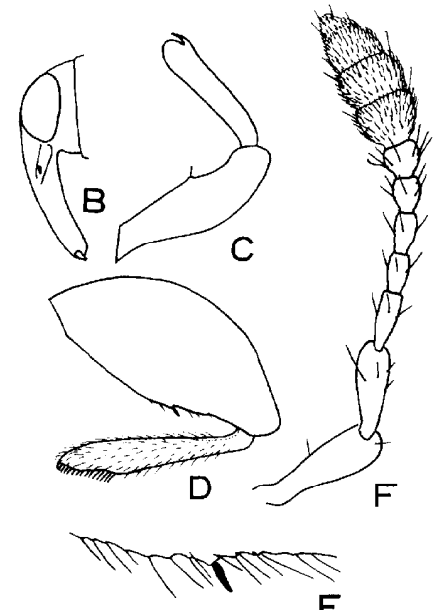

E

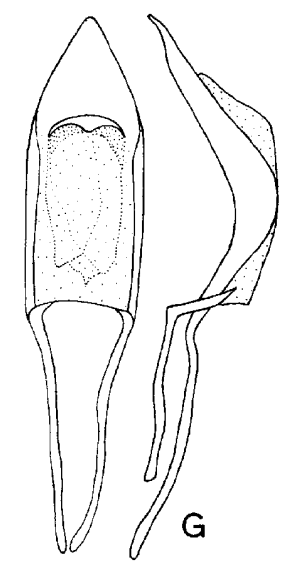

Fig. 22. Rhynchaenus (Alyctus) galloisi (Kôno). A : Male. B : Male head. C : Fore leg. D : Hind leg. E: Posterior margin of hind femur, enlarged. F: Antenna. G: Penis. 
Pronotum 2/3 times as long as wide, with a few erect setae at anterior and posterior corners.

Elytra $5 / 4$ times as long as wide, intervals broad, shiny, striae each with a row of greyish fine hairs.

Anterior four femora armed. Hind femora 2.3 times as long as wide, posterior margin weakly curved, with a spine. Hind tibiae straight, simple.

Fore coxal cavities narrowly distant. Metasternum and basal two ventrites shiny, punctate, third and fourth ventrites excepting the bases and fifth ventrites rugulose and coriaceous.

Length : 2.5-2.8 $\mathrm{mm}$.

Specimens eXamined : 62 exs. from Hokkaido (Nibushi), Aomori (Shimokita), Iwate (Morioka), Miyagi (Sendai), Akita (Tazawako), Niigata (Kurokawa, Minakami, Mt. Gozu, Nagaoka, Itoigawa, Is. Sado), Ishikawa (Wajima), Gumma (Shinto), Chiba (Mt. Kiyosumi), Kanagawa (Tsukui), Nagano (Ina, Shirahone), Kochi (Jinzenji, Kuroson, Nishigoya), Fukuoka (Mt. Hiko, Fukuoka, Tashiro), Nagasaki (Mt. Kompira), Is. Tsushima, and Is. Yaku.

Distribution: Japan (Hokkaido, Honshu, Shikoku, Kyushu, Is. Tsushima, Is. Yaku), and China (Fukien).

Biology : The larvae mine the leaves of Quercus acutissima and Q. serrata (Kunugi and Konara in Japanese).
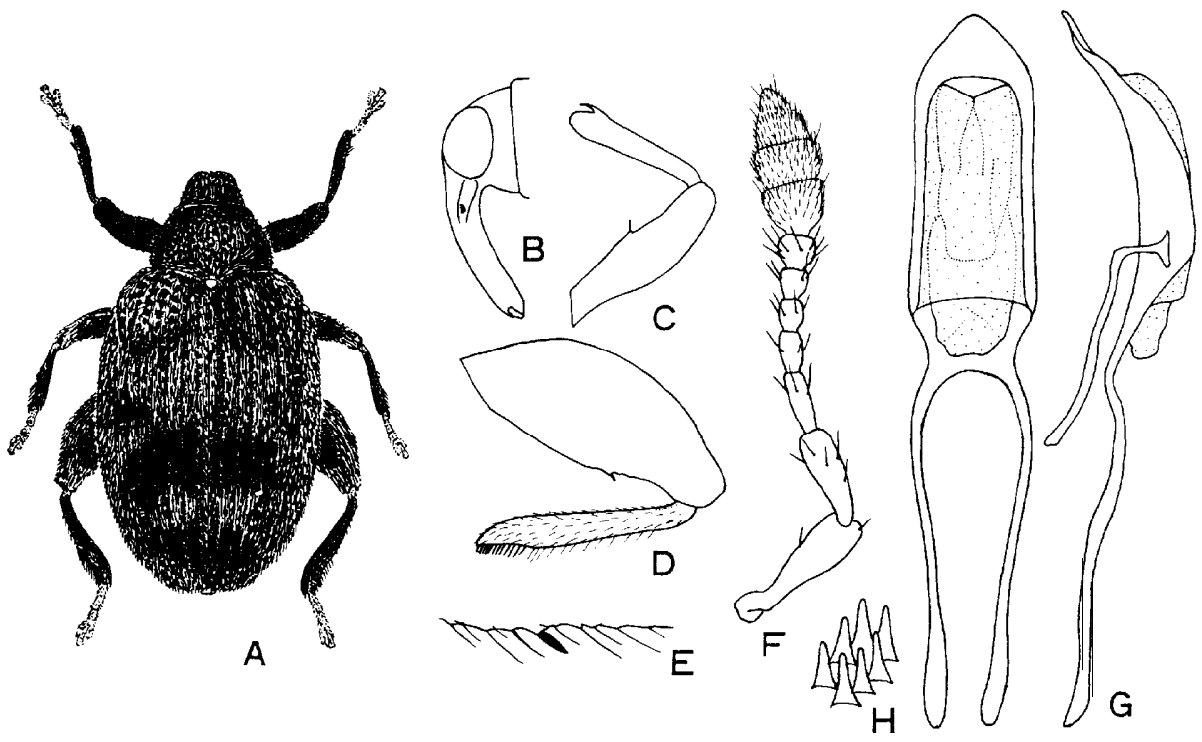

Fig. 23. Rhynchaenus (Alyctus) jozanus (Kôno). A : Male. B : Male head. C : Fore leg. D : Hind leg. E : Posterior margin of hind femur, enlarged. F : Antenna. G : Penis. H : Asperities of internal sac, enlarged. 


\section{Rhynchaenus jozanus (Kôno)}

Orchestes jozanus Kôno, 1930, Ins. Mats., V : 27 (Sapporo, Jozankei).

Rhynchaenus jozanus: Klima, 1935, Col. Cat., 145, Rhynchaeninae :16. -Ter-Minassian, 1953, Ent. Oboz, XXXIII : 314. -Morimoto, 1962, Sci. Bull. Fac. Agr., Kyushu Univ., 19 : 186 (Hokkaido, Honshu). -Morimoto, 1984, Col. Jap., IV : 296, pl. 58, fig. 23.

Very close to galloisi Kôno, but separable from it by the following points :

Forehead between eyes closest at posterior $1 / 3$, then slightly widening anteriorly; dorsal outline of rostrum and head weakly depressed at base ; pronotum $2 / 3$ times as long as wide, without or with one seta at hind angle; hairs yellowish grey to golden grey and sparser. Rostrum 3.6 (male) or 4.3 (female) times as long as wide, antenna1 insertion index 26 (male) or 24 (female), hind femora 2.52 times as long as wide.

Length : 2.4-2.8 $\mathrm{mm}$.

SPECIMENS EXAMINED: 48 exs. from Hokkaido (Ashoro), Aomori (Shimokita), Akita (Mt. Komagatake), Niigata (Kurokawa, Mt. Kurohime, Nakago), Tochigi (Nikko), Yamanashi (Masutomi, Aokigahara), Nagano (Mt. Asama, Iriyamabe, Ina, Shirahone, Tobiratoge), Fukui (Koike), and Oita (Mt. Kuju).

Distribution : Japan (Hokkaido, Honshu, Kyushu).

Host ${ }_{\mathrm{rRg}}$ : Several specimens were collected from Malus sieboldii (Zumi in Japanese) at Mt. Asama.

\section{Rhynchaenus kimotoi sp.nov.}

Black, shiny, antennae and tarsi reddish brown; derm with blackish brown fine hairs and with greyish hairs, the latter scattered on each side of the median area on pronotum and forming short indistinct postscutellar patch ; head behind eyes, prosternum, fore coxae, lateral pieces of meso- and metathoraces with sparse greyish hairs.

Head densely punctate, finely hairy ; forehead between eyes linear, slightly widening anteriorly. Rostrum 3.9 (male) or 4.2 times (female) as long as wide, punctate at sides. Antennae with scape as long as first and second of funicle combined, club a little longer than scape, antennal insertion index 27 (male) or 36 (female).

Pronotum 1.4 times as wide as long, widest at $1 / 3$ from the base, subapical constriction weak, disk with dense punctures and coriaceous, without erect seta at sides.

Scutellum coriaceous, with a few fine hairs.

Elytra 1.44 times as long as wide, evenly curved at sides, intervals each with a row of hairs, shiny, weakly rugose at base, striae as wide as intervals, punctures deep on basal half.

Fore and mid femora armed with spine. Hind femora 2.67 times as long as wide, posterior margin with three denticles, four long setae and two long spines. Hind tibiae straight, simple. 


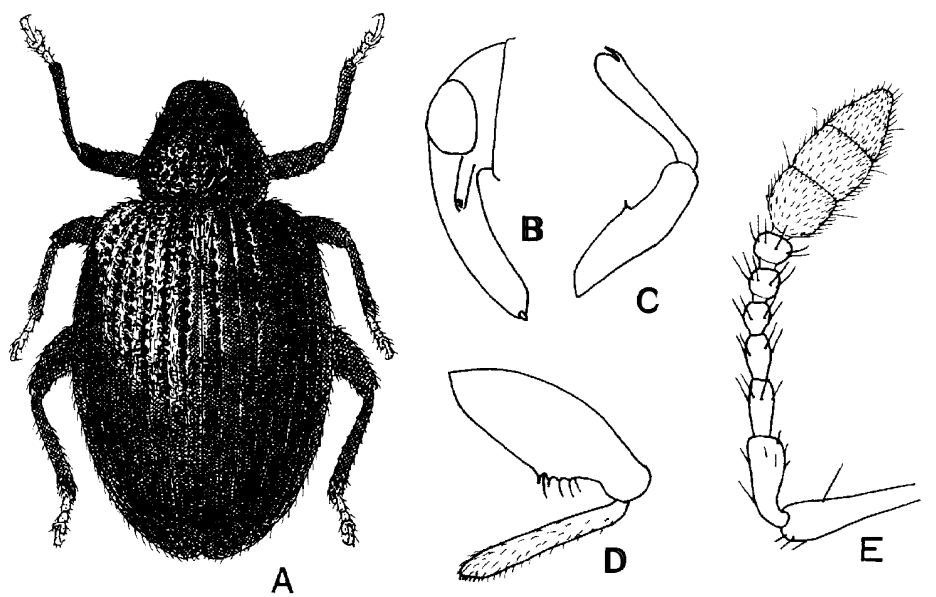

Fig. 24. Rhynchaenus (Alyctus) kimotoi sp. nov. A : Female. B : Male head. C : Fore leg. D : Hind leg. E: Antenna.

Fore coxal cavities contiguous. Lateral surfaces of thorax and venter, posterior margins of third and fourth ventrites, and fifth ventrites coriaceous.

Length : 2.0-2.4 mm.

Holotype female (Type No.2457, Kyushu Univ.), Shirahone, Nagano Pref., 19. vii. 1956, S. Kimoto leg.

Paratypes : Yunomata, Oohata-Machi, Aomori Pref., one female, 11. vii. 1956, K. Morimoto leg. Mt. Asama, Nagano Pref., one male, 27. vii. 1962, K. Morimoto leg. Same data as holotype, one female.

Distribution: Japan (Honshu).

BIOLOGY : Unknown.

This new species is easily recognized by the smaller size and obscure clothing.

\section{Rhynchaenus aterrimus (Roelofs)}

O rchestes aterrimus Roelofs, 1874, Ann. Soc. Ent. Belg., XVII : 166 (Japon). -Kôno, 1930, Ins. Mats., $\mathrm{v}: 29$.

Rhynchaenus aterrimus: Klima, 1935, Col. Cat,, 145, Rhynchaeninae : 10. -Ter-Minassian, 1953, Ent. Oboz., XXX111:323. -Morimoto, 1984, Col. Jap., IV : 297.

O rchestes mumon Kôno, 1930, Ins. Mats., V : 24 (Sakhalin). Syn. nov.

Rhynchaenus mumon: Klima, 1935, Col. Cat., 145, Rhynchaeninae :17. -Kôno, 1935, Ins. Mats., X : 62 (Etorofu). -Ter-Minassian, 1953, Ent. Oboz., XXXIII : 318. -Morimoto, 1958, Kontyû, 26 : 186 (Hokkaido, Honshu). -Morimoto, 1962, Sci. Bull. Fac. Agr., Kyushu Univ., 19 : 186 (Hokkaido, Honshu, Sakhalin). -Morimoto, 1984, Col. Jap., IV : 296.

Black, claws reddish brown, antennal scape dark brown; derm clothed with fine greyish hairs, without hairy patch.

Forehead between eyes as wide as apex of scape. Rostrum 4.0 (male) or 4.3 (female) times as long as wide. Antennae with scape as long as club. 
Pronotum 1.4 times as wide as long, widest behind the middle, sides rather strongly rounded, subapical constriction slight at sides and obsolete dorsally, disk punctate, inside of the punctures partly coriaceous.

Elytra 1.6 times as long as wide, evenly narrowed to apex, intervals with two irregular rows of fine hairs, intervals each with a row of similar hairs, septa of punctures as high as interval.

Fore and mid femora unarmed. Hind femora 2.89 times as long as wide, posterior margin with four to five denticles and four to five long setae. Hind tibiae straight, simple.

Fore coxal cavities contiguous. Lateral surfaces of thorax and venter, posterior margin of fourth ventrite, and fifth ventrite finely coriaceous.

Length 2.8-3.4 mm.

Specimens examined : 35 exs. from Hokkaido (Nibushi, Mt. Daisetsu), Toyama (Mt. Tateyama, Arimine), Ishikawa (Iwama spa), Nagano (Karuizawa), Fukui (Koike), Gifu (Hirayu), Kumamoto (Mt. Aso), and Oita (Mt. Daisen).

Distribution : Japan (Hokkaido, Honshu, Kyushu), Kuril Isls., and Sakhalin.

BIology: The adults feed on the leaves of Alnus firma (Yashabushi in Japanese) at Mt. Aso.

The unarmed anterior femora, dark tarsi and antennae, rather slender hind femora, simple hind tibiae, and wider elytra at base are characteristic of this species.

The holotype in the British Museum (Natural History) was lost leaving the pinned card and labels.

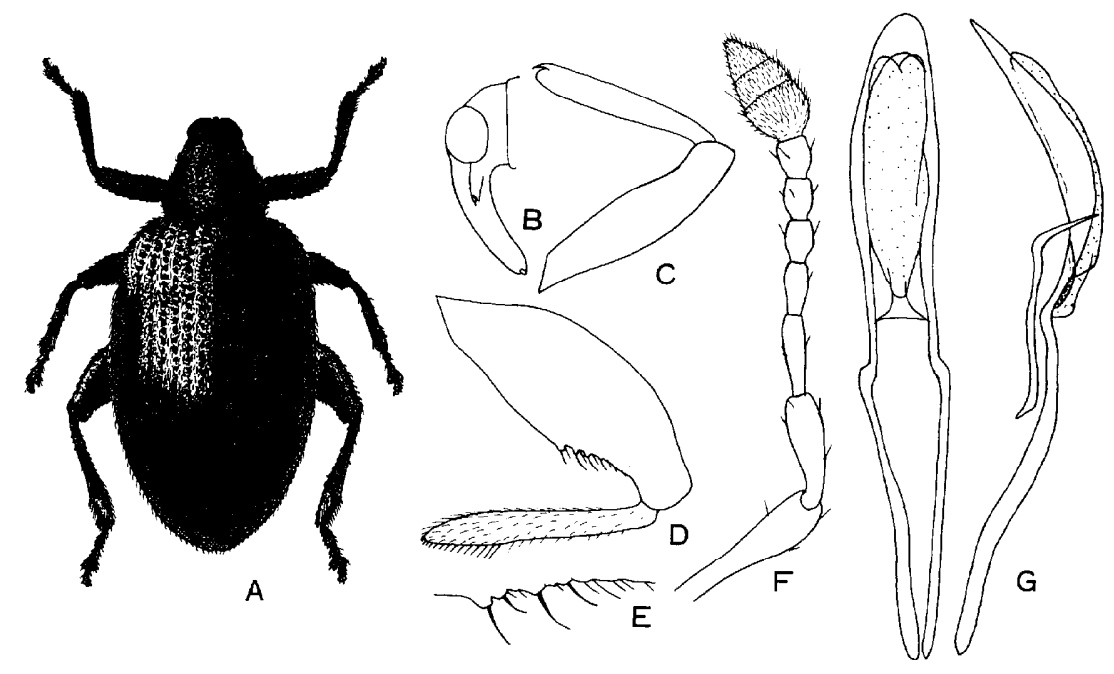

Fig. 25. Rhynchaenus (Alyctus) aterrimus (Roelofs). A : Male. B : Male head. C : Fore leg. D : Hind leg. E: Posterior margin of hind femur, enlarged. F: Antenna. G : Penis. 


\title{
Subgenus O rchestes Illiger
}

\author{
Key to species
}

1(4): Fore and mid femora unarmed. Elytra with greyish postscutellar patch and narrow band along basal margin.

2(3): Rostrum depressed at base. Pronotum widest at basal third, 1.5 times as long as wide. Elytra about 1.5 times as long as wide, rounded posteriorly. Black, rostrum, antennae, tarsi, and fore and mid legs reddish brown in male ; black, antennae and

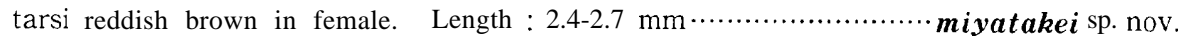

3(2): Rostrum and forehead forming a continuous curve. Pronotum widest at base, 1.8 times as wide as long. Elytra 1.32-1.36 times as long as wide, truncate at apex. Head, base of rostrum, thorax, and scutellum black, antennae and tarsi yellowish brown, fore and mid femora and tibiae reddish brown, elytra, venter and hind legs chestnut brown. Length :2.0-2.1 $\mathrm{mm}$.....

truncatipennissp. nov.

4(1): Fore and mid femora each with a spine or seta born on a denticle.

5(20): Elytra clothed with concolorous uniform fine hairs, without any hairy marking.

6(7): Body $1.8 \mathrm{~mm}$ in length, entirely rusty red. Hind femora 2.2 times as long as

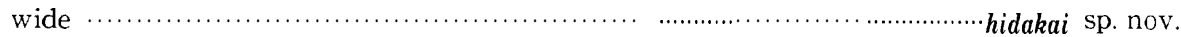

$7(6)$ : Body more than $2.0 \mathrm{~mm}$ in length.

$8(9)$ : Derm entirely black, shiny, with sparse brownish black pubescence on dorsal surface. Forehead between eyes very narrow at posterior third, then weakly widening anteriorly. Pronotum without erect setae at sides. Length : 2.9-3.3 mm . *nitens sp. nov.

$9(8)$ : Derm bicolorous, black with reddish antennae and tarsi or reddish with blackish sternites. Elytra distinctly hairy. Forehead between eyes more or less wider. Pronotum with erect setae at sides.

10(11): Head, pronotum and elytra concolorous, rusty red to rusty yellowish red, meso- and metasterna, metepisterna and basal ventrites black. Body larger, usually 3.5-4.0 $\mathrm{mm}$ in length

hustachei (Klima)

11(10): Head always black. Body smaller than $3.4 \mathrm{~mm}$ in length.

12(13): Elytra oblong-oval, 1.65-1.70 times as long as wide. Pronotum and elytra less convex, pronotum with weak median sulcus. Forehead between eyes a little wider than scape. Pronotum, elytra, legs and apical ventrites reddish, elytra with blackish patches in variable shape, pronotum often with broad black band. Length :3.0-3.5

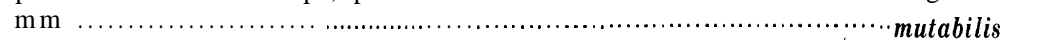

(Boheman)

13(12): Elytra oval, 1.4-1.6 times as long as wide, usually immaculate (rarely with asymmetrical indistinct black patches in some horii). Body less than $3.1 \mathrm{~mm}$ in length.

14(15): Body smaller, 2.2-2.6 mm in length. Elytra 1.42-1.47 times as long as wide, broadly rounded posteriorly, each interval with two rows of hairs .horii Kôno

15(14): Body 2.6-3.1 mm in length. Elytra 1.5-1.6 times as long as wide.

16(17): Elytra with two rows of hairs on each interval, shiny. Black, antennae and tarsi

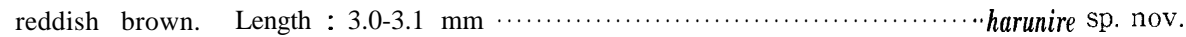

17(16): Each interval with three rows of hairs, pronotum, elytra and legs often reddish.

18(19): Elytra broadly rounded posteriorly. Pronotum 1.40-1.48 times as wide as long. Black, prothorax and elytra rusty red, pronotum often with broad blackish band, elytra often infuscate excepting basal and apical margins. Length : 2.6-3.1

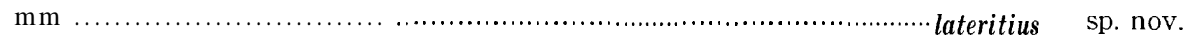

19(18): Elytra narrowly rounded posteriorly. Pronotum 1.3-1.4 times as wide as long. Body coloration variable, pronotum and elytra immaculate. Length : 2.6-3.1

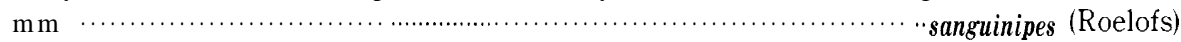

20(5): Elytra mottled with two or three kinds of hairs. 
21(22): Elytra with black fascicles on third and fifth intervals at subapical calli formed of posteriorly directing bristles, without postscutellar patch. Pronotum with a pair of black fascicles, which often indistinct. Rusty red, meso- and metathoraces, lateral and apical margins of elytra dark reddish. Length : $2.7-3.3 \mathrm{~mm}$... dorsoplanatus (Roelofs)

22(21): Elytra without fascicles on declivity.

23(28): Body 3.2-4.3 $\mathrm{mm}$ in length.

24(25): Elytra with yellowish postscutellar patch and three greyish bands. Pronotum strongly convex dorsally, with a median sulcus. Length : $3.2-3.5 \mathrm{~mm}$. trifasciatus sp. nov.

25(24): Elytra without distinct bands. Body 3.5-4.3 $\mathrm{mm}$ in length.

26(27): Elytra with white postscutellar patch, alternate intervals with blackish small spots, 1.4 times as long as wide. Black, antennae and claws reddish brown, apical three ventrites and legs often dark reddish to blackish red. Length. 3.5-4.3 mm. excellens (Roelofs)

27(26): Elytra without postscutellar patch, densely covered with greyish brown and greyish stout hairs, the latter often forming vague band at apical third, alternate interval often with several bare patches, 1.65-1.70 times as long as wide. Legs and antennae rusty red to brownish red. Length : $3.8-4.8 \mathrm{~mm} \ldots \ldots \ldots \ldots \ldots \ldots \ldots \ldots$ japonicus (Hustache)

28(23): Body 2.1-2.9 $\mathrm{mm}$ in length.

29(32): Elytra without postscutellar patch. Derm reddish at least on dorsum.

30(31): Yellowish red to reddish, antennae and legs paler. Elytra with ochreous three hairy bands, Pronotum 1.60-1.74 times as wide as long, widest at base. Length : 2.7-2.9 $\mathrm{mm}$

31(30): Rostrum and underside black, vertex, antennae, pronotum, elytra and legs reddish brown to rusty red, elytra with two dark brown bands, often bands confluent and occupying basal two-thirds of elytra. Elytra clothed with yellowish grey hairs on reddish area, and with brownish black hairs on darker area. Length : 2.7-2.9

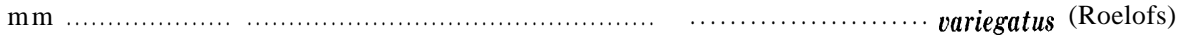

32(29): Elytra with postscutellar white or greyish patch.

33(36): Elytra with two greyish bands, bands often fragmentary.

34(35): Elytra longer, 1.51-1.53 times as long as wide, each interval with two rows of minute

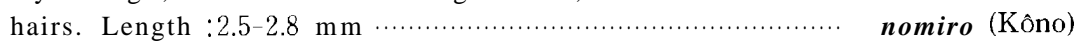

35(24): Elytra broader, 1.32-1.35 times as long as wide, each interval with a row of long

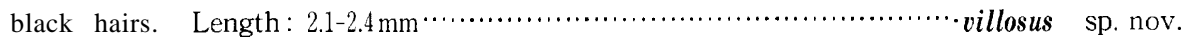

36(33): Elytra with greyish band along basal margin, often with scattered greyish hairs. Pronotum with a pair of greyish stripes, which often obsolete. Length : 2.3-2.9 $\mathrm{mm}$

takabayashii (Kôno)

\section{Rhynchaenus miya takei sp. nov.}

Male : Black ; rostrum, antennae, tarsi, and fore and mid legs reddish brown. Dorsal surface with fine black hairs, mixing a few greyish hairs on pronotum, elytra with greyish postscutellar patch and indistinct greyish band along basal margin ; base of rostrum, lateral and ventral surface of head, mesothorax, anterior margin of metasternum, metepisterna, and fore and mid coxae with white hairs, femora with similar hairs, but a little thinner, metasternum and venter with greyish sparse hairs.

Head coriaceous, with dense punctures, forehead between eyes linear. Rostrum 4.1 times as long as wide in both sexes, rather strongly curved near base, dorsal outline of head and rostrum distinctly depressed at base, dorsal surface impunctate, shiny, lateral surface with two rows of weak punctures, the dorsal row reaching the apex, the 
ventral row reaching anteriorly from scrobe to apical third. Antennae with scape shorter than first and second of funicle combined, antennal insertion index 17 in both sexes.

Pronotum $2 / 3$ times as long as wide, subapical constriction obsolete, disk with dense punctures, coriaceous, with several black erect setae at sides.

Scutellum circular, coriaceous, with a few black fine hairs.

Elytra about 1.5 times as long as wide, parallel-sided from humeri to the middle, then evenly curved and narrowed posteriorly, coriaceous, intervals rugulose at base, each with irregular two rows of fine hairs, striae each with a row of black fine hairs.

Pygidium fully exposed, shiny, strongly punctate in male ; fully or partly exposed, coriaceous, and strongly punctate in female.

Fore coxal cavities contiguous. Undersurface more or less coriaceous except for the basal margins of second to fourth ventrites, punctate, the punctures being smaller and denser at posterior margins of second to fourth, and entire fifth ventrites, first ventrite strongly depressed at the middle, hairs on the first to fourth ventrites directing posterointernally at median area.

Fore and mid femora unarmed with spine. Hind femora 2.2 times as long as wide, with about ten denticles, two long setae, two long spines and eight to nine short spines at posterior margin. Hind tibiae curved, with long setae along dorsal margin of flat surface.

Female : Black, antennae and tarsi reddish brown; hairs on the underside finer and thinner than those in male.

Length : 2.4-2.7 mm.

Holotype male (Type No. 2458, Kyushu Univ.) and 86 paratypes: Nagai Park, Osaka City, 14. viii. 1983, Y. Miyatake leg.

Distribution: Japan (Honshu : Osaka).

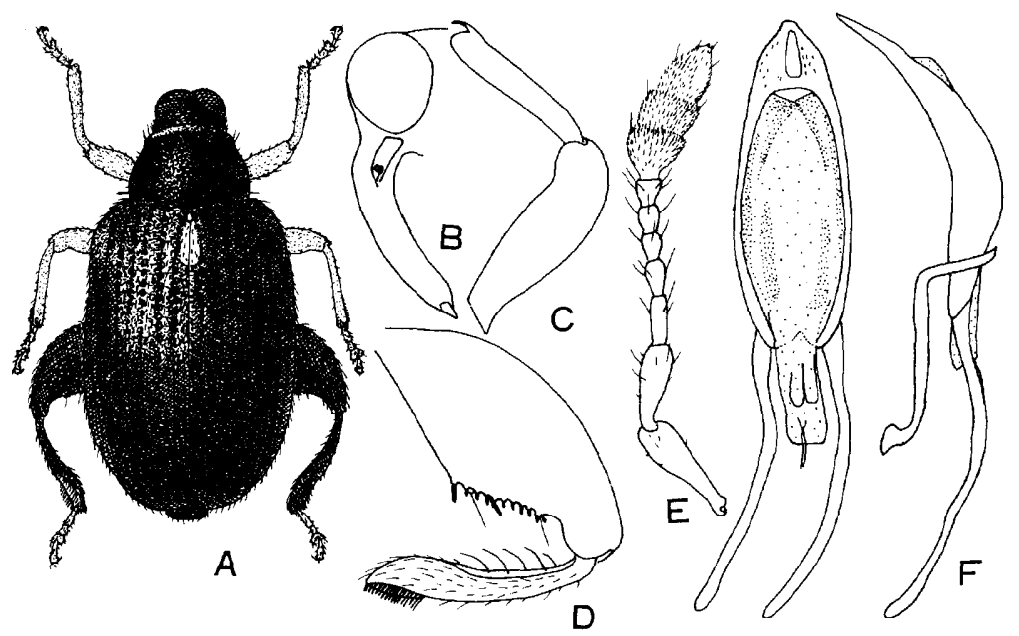

Fig. 26. Rhynchaenus (Orchestes) miyatakei sp. nov. A : Male. B : Male head. C : Fore leg. D : Hind leg. E: Antenna. F : Penis. 
BIOLOGY: Mr. Miyatake found a mass of present new species on the leaves of Pterocarya stenoptera (Shinasawagurumi in Japanese).

The present new species is similar to matsumuranus (Kôno) in having the similar rostrum, unarmed anterior femora, similarly armed hind femora, but differs from the latter by the colorations of hairs and legs.

R. matsumuranus was described by Kôno, 1930, in Ins. Mats., V : 26, without giving any data on specimen. Through the courtesy of Prof. T. Kumata, I have examined the holotype of this species preserved in the Entomological Institute, Hokkaido University, which is a female and collected at Giran, Formosa, 20. xi. 1906, by S. Matsumura.

\section{Rhynchaenus sanguinipes (Roelofs)}

Orchestes sanguinipes Roelofs, 1874, Ann. Soc. Ent. Belg., XVII : 165. - Hustache, 1920, Bull. Mus. Hist. Nat. Paris, (6) : 634. -Kôno, 1930, Ins. Mats., V : 24.

Rhynchaenus sanguinipes : Klima, 1935, Col. Cat., 145, Rhynchaeninae : $29 . \quad$-Ter-Minassian, 1953, Ent. Oboz., XXXIII : $317 . \quad$-Obara, 1957, Shinrin Boeki News, 6 (11) : 242 (biology). -Morimoto, 1962, Sci. Bull. Fac. Agr., Kyushu Univ., 19: 187 (Honshu, Shikoku, Kyushu). -Nakane, 1963, Icon. Ins. Jap. col. nat. ed., II : 378, pl. 189, fig. 17. - Ebine et al., 1973, Shinrin Boeki, 22 (12) : 282 (control). -Kobayashi, 1977, Pests of the Garden Trees, II : 162 (biology, control). -Morimoto, 1984, Col. Jap., IV : 296, pl. 58, fig. 20.

O rchestes sanguinipes Roelofs var. nigripes Hustache, 1920, Bull. Mus. Hist. Nat. Paris, (6) : 635. -Kôno, 1930, Ins. Mats., V : 25.

Rhynchaenus sanguinipes Roelofs ab. nigripes: Klima, 1935, Col. Cat., 145, Rhynchaeninae : 29.

Orchestes sanguinipes Roelofs var. mixtus Hustache, 1920, Bull. Mus. Hist. Nat. Paris, (6) : 635. -Kôno, 1930, Ins. Mats., V : 25.

Rhynchaenus sanguinipes Roelofs ab. mixtus: Klima, 1935, Col. Cat., 145, Rhynchaeninae : 29.

Rhynchaenus mutabilis Kaminaga et al.(nec Boheman),1973, Shinrin Boeki, 22 (4) : 104 (biology, control).

This species is considerably variable in body color as follows :

Type I (f. nigripes): Black, antennae and tarsi reddish brown.

Type II (f. typica): Black, antennae and legs reddish brown.

Type III (f. mixtus): Black, antennae, legs, elytra and apical two to four ventrites reddish brown.

Derm uniformly covered with concolorous brownish grey fine hairs. Forehead between eyes slightly narrower than scape and weakly widening anteriorly. Rostrum 3.4 times as long as wide. Antennal insertion index 34.8 (male) or 33.3, (female). Pronotum 1.3-1.4 times as wide as long, with five to eight erect brown setae at each side and six to eight pairs of suberect setae along anterior margin, densely punctate and coriaceous. Scutellum subtriangular. Elytra 1.5-1.6 times as long as wide, not coriaceous, each interval with irregular three rows of hairs, stria with a row of hairs. Fore and mid femora armed with spine. Hind femora 2.0-2.1 times as long as wide, with seven denticles, four long setae, two long spines and nine short spines along posterior margin.

Length : 2.6-3.1 $\mathrm{mm}$.

Spectmens examined: 620 exs. from Iwate, Niigata, Ibaragi, Gumma, Chiba, 


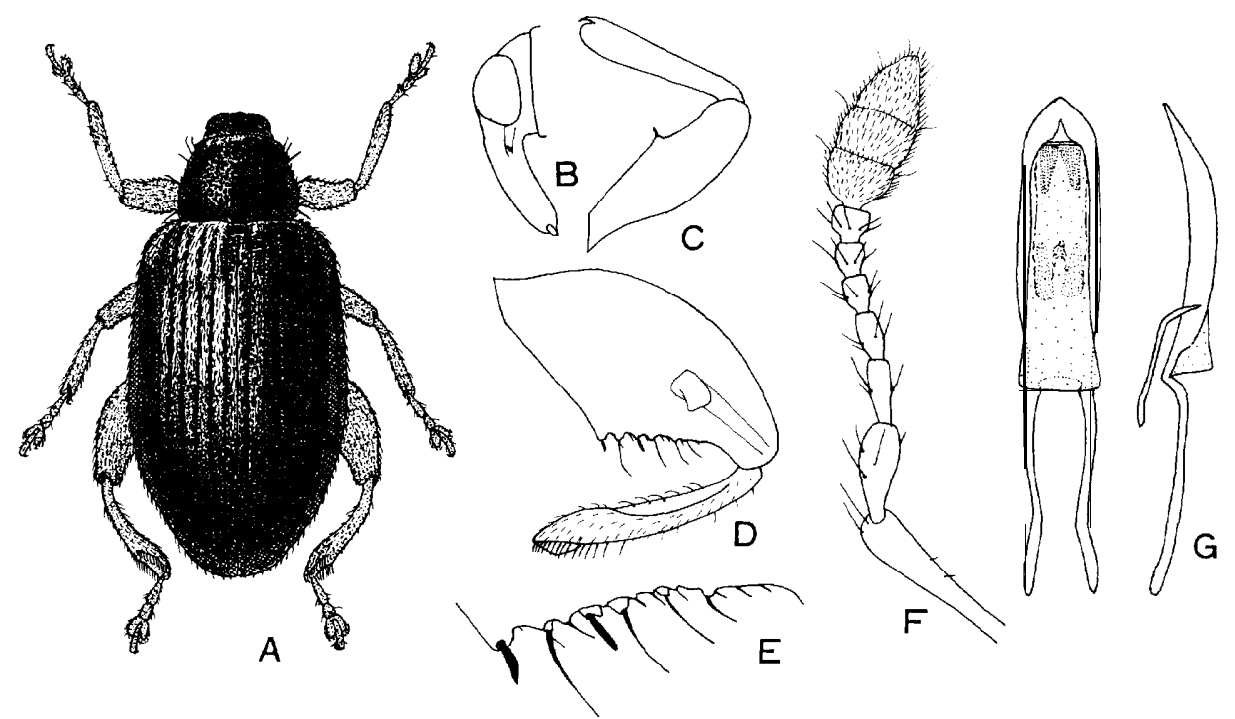

Fig. 27. Rhynchaenus (Orchestes) sanguinipes (Roelofs) A : Male. B : Male head. C : Fore leg. D: Hind leg. E : Posterior margin of hind femur. F: Antenna. G : Penis.

Nagano, Fukui, Gifu, Tottori, Fukuoka, Saga and Nagasaki Prefs, Is. Sado, and Tsushima.

Distribution: Japan (Honshu, Shikoku, Kyushu, Sado, Tsushima).

Biology : This is a serious pest to Zelkova serrata (Keyaki in Japanese). They hibernate in adult stage under loose bark, emerge in early spring, fly to their host tree, and feed by eating circular holes in opening buds and new leaves. The eggs are laid in small pits on the midrib of the underside of leaves, and the larvae feed within the tissues of the leaves, forming large blotchy mines. Infested leaves by larvae are usually deformed, and severely infested leaves by larvae and adults are discoloured in May and June. New adults appear from the middle May to early June.

\section{Rhynchaenus lateritius sp. nov.}

Head, rostrum, coxae, meso- and metathoraces, abdomen and scutellum black, antennae, legs, prothorax and elytra rusty red, pronotum often with broad blackish band, elytra often infuscate excepting basal and apical margins ; derm clothed with concolorous greyish brown fine hairs.

Head punctate, coriaceous, without median carina ; forehead between eyes as wide as the apex of scape. Rostrum 3.2 (male) or 3.9 (female) times as long as wide, with shiny median carina at base, punctate at sides, coriaceous behind antennal sockets. Antennae with scape as long as first and second of funicle combined, antenna1 insertion index 40.7 (male) or 41.4 (female).

Pronotum 1.40-1.48 times as wide as long, widest at basal third, disk with dense 

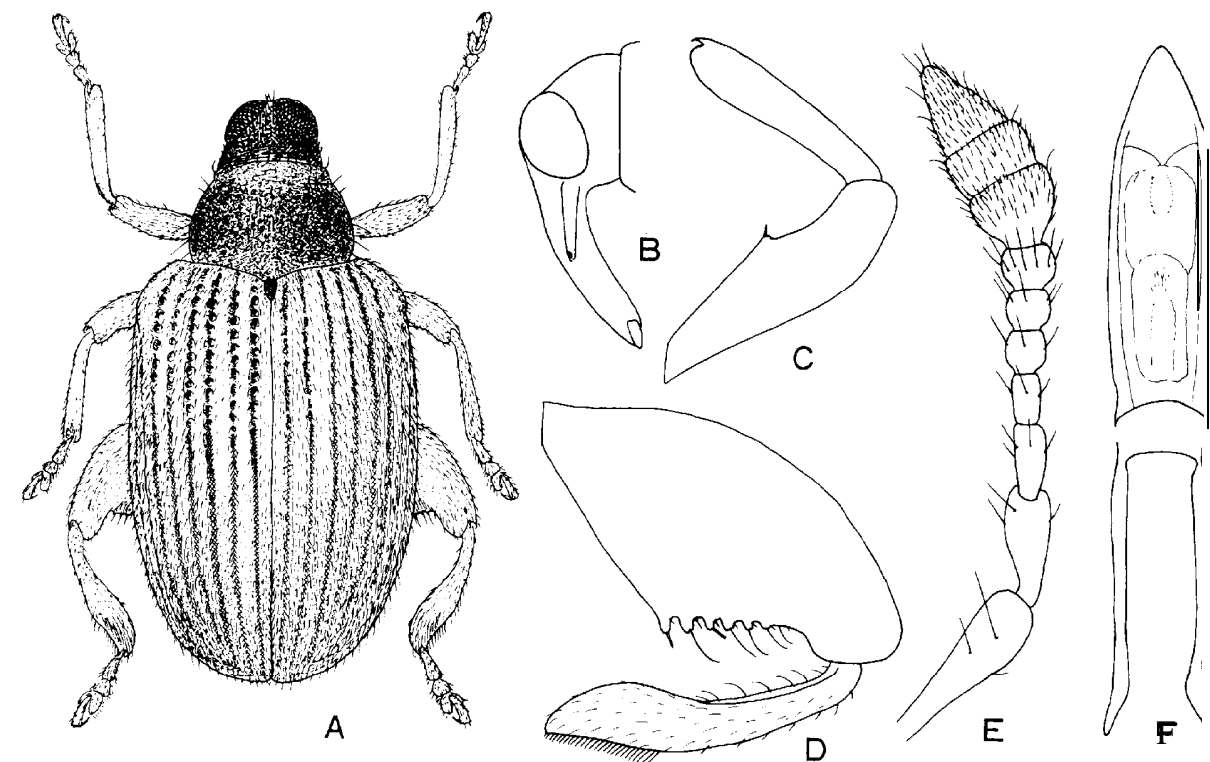

Fig. 28. Rhynchaenus (Orchestes) lateritius sp. nov. A : Male. B : Male head. C : Fore leg. D : Hind leg. E : Antenna. F : Penis.

punctures, coriaceous, median area longitudinally flattened, each side with three to six erect setae.

Scutellum oval, punctate, coriaceous, with fine hairs.

Elytra 1.50-1.53 times as long as wide, intervals flat, shiny, each with three rows of recumbent hairs, striae shallow, each puncture bearing a short fine hair.

Fore coxal cavities and coxae contiguous. Underside punctate, metasternum transversely strigulate, lateral margins of thorax and venter coriaceous.

Fore and mid femora armed with spine. Hind femora twice as long as wide, with six denticles, five long setae, two long spines and about twelve short setae along hind margin.

Length : 2.6-3.1 $\mathrm{mm}$.

Holotype male (Type No.2459, Kyushu Univ.), Aizankei, Mt. Daisetsu, Hokkaido, 27. vii. 1955 , K. Morimoto leg.

Paratypes : Same data as holotype, one male and three females. Yukomanbetsu, Mt. Daisetsu, Hokkaido, one female, 24. vii. 1955, K. Morimoto leg. Mt. Meakandake, Hokkaido, one female, 30. vii. 1962, Y. Miyatake leg. Ashoro, Hokkaido, two females, 22. v. 1957, M. Takahashi and 24. vii. 1959, K. Morimoto leg. Meto Spa, Hokkaido, one male, 28. vii. 1962, Y. Miyatake leg. Nopporo, Hokkaido, one male, 14. vii. 1962, Y. Miyatake leg.

DistRibution : Japan (Hokkaido).

Biology : Unknown.

This new species is similar to the type IV of horii, but the hairs on elytra are much 
smaller and the body is larger.

\section{Rhynchaenus horii Kôno}

Rhynchaenus horii Kôno, 1937, Ins. Mats., XI : 129 (Is. Meshima). -Morimoto, 1955, Gensei, IV : 5

(Kochi: Is. Okinoshima). -Morimoto, 1962, Sci. Bull. Fac. Agr., Kyushu Univ., 19 :186.

- Imasaka and Makihara, 1981, Nat. Hist. Is. Danjo: 106. -Morimoto, 1984, Col. Jap., IV : 297.

Body colour variable as follows :

Type I : Black, apex of rostrum, antennae and tarsi yellowish brown.

Type II : Black, apex of rostrum, antennae, tarsi and elytra yellowish brown, elytra often with indistinct fuscous patches.

Type III : Black, apex of rostrum, antennae, legs and elytra yellowish brown, elytra often with indistinct fuscous patches.

Type IV (f. typica): Apex of rostrum antennae, legs, pronotum, elytra and third to fifth ventrites yellowish brown ; head, rostrum excepting apex, scutellum, underside of thorax and basal ventrites black.

Derm uniformly covered with concolorous brownish grey fine hairs. Forehead between eyes as wide as or slightly narrower than apex of scape. Rostrum 3.2 (male) or 3.7 (female) times as long as wide. Antennae with scape as long as club and a little shorter than first and second of funicle combined, antennal insertion index 41 (male) or 40 (female).

Pronotum $2 / 3$ times as long as wide, widest behind the middle, strongly rounded at sides, subapical constriction very weak, disk densely punctate, coriaceous, side margin with two to five erect yellowish brown setae. Scutellum subtriangular, with a few fine hairs. Elytra 1.42-1.47 times as long as wide, each interval with irregular two rows of hairs, stria with a row of similar hairs.

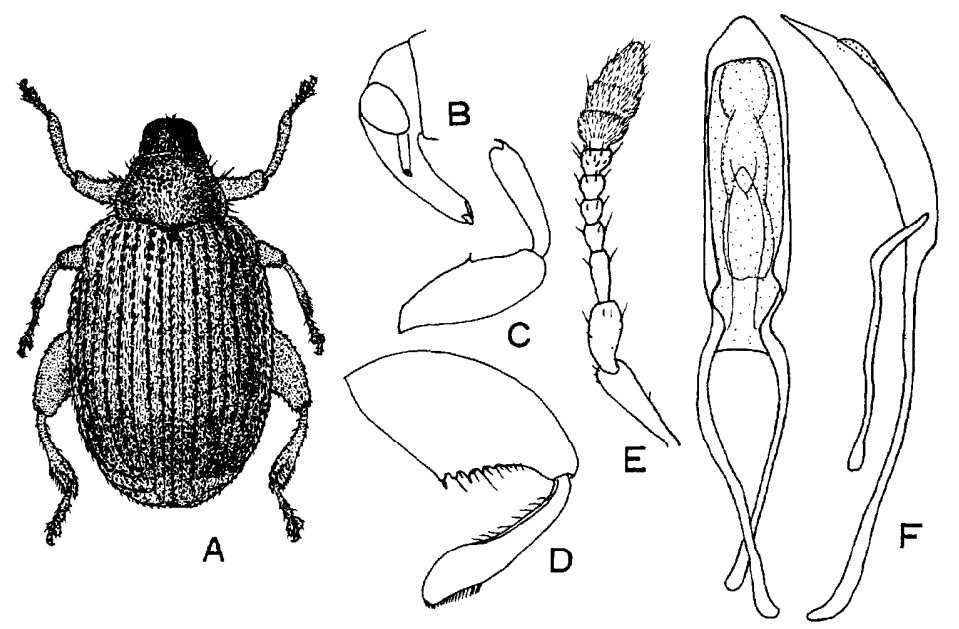

Fig. 29. Rhynchaenus (Orchestes)horï Kôno. A : Male. B : Male head. C : Fore leg. D : Hind leg. E: Antenna. F : Penis. 
Fore coxae contiguous. Fore and mid femora armed with spine. Hind femora 2.0-2.1 times as long as wide, with six to seven denticles, five to six long setae, two long spines and eight to nine short spines along posterior margin. Hind tibiae curved.

Length : 2.2-2.6 mm.

SPECIMENS eXAMined : About 200exs. from Kanagawa (Yokosuka : Mt. Takeyama), Fukui (Sanrihama), Kochi (Is. Okinoshima), Fukuoka (Mt. Homan, Is. Shikanoshima, Mt. Tachibana, Mt. Joyama, Nata, Mt. Fukuchi), Tsushima, Is. Meshima, and Is. Akuseki.

Distribution : Japan (Honshu, Shikoku, Kyushu, Tsushima, Danjo Isls., and Is. Akuseki).

Bıology : The larvae and adults attack Celtis sinensis (Enoki in Japanese) and give a serious damage to the young leaves. New adults occur in May in Fukuoka.

This species is similar to sanguinipes (Roelofs), but elytra are more strongly rounded posteriorly, body is shorter, and pronotum and elytra are relatively wider.

\section{Rhynchaenus harunire sp.nov.}

Black, antennae and tarsi reddish brown, mandibles and bases of tibiae dark reddish brown to reddish brown; derm uniformly covered with concolorous brownish grey fine hairs.

Head rugulose, punctate, coriaceous, without median bare line ; forehead between eyes as wide as apex of scape, slightly widening anteriorly, with two rows of hairs at narrowest portion. Rostrum 2.8 (male) or 3.0 (female) times as long as wide, weakly curved, densely punctate and coriaceous at base between scrobes, with shiny median keel, the latter widening and weakened anteriorly, with a row of haired punctures along dorsolateral margin and several punctures before antennal socket at each side, antennal scrobe and lateral margins at base coriaceous. Antennae with scape as long as first and second of funicle combined, antennal insertion index 34.5 (male) or 40.0 (female).

Pronotum 1.39-1.44 times as wide as long, widest at basal third, then weakly rounded to the indistinct subapical constriction, disk with dense punctures, inside of the punctures or whole surface coriaceous, side margin with three to six erect brown setae.

Scutellum oval, punctate, with fine hairs.

Elytra 1.54 times as long as wide, intervals rugulose at base, each with two rows of fine hairs, striae each with a row of similar hairs.

Fore coxal cavities contiguous, fore coxae slightly separated. Undersurface punctate, metasternum transversely strigulate, lateral margins of thorax and venter, and posterior margins of third and fourth ventrites, and fifth ventrite coriaceous. Fore and mid femora armed with spine. Hind femora 2.1 times as long as wide, with seven denticles, four to five long setae, four to five long spines, and ten to fifteen short spines along posterior margin.

Length : 3.0-3.1 mm.

Holotype male (Type No. 2460, Kyushu Univ.), Kurifuji, Yabe, Kumamoto Pref., 9. 

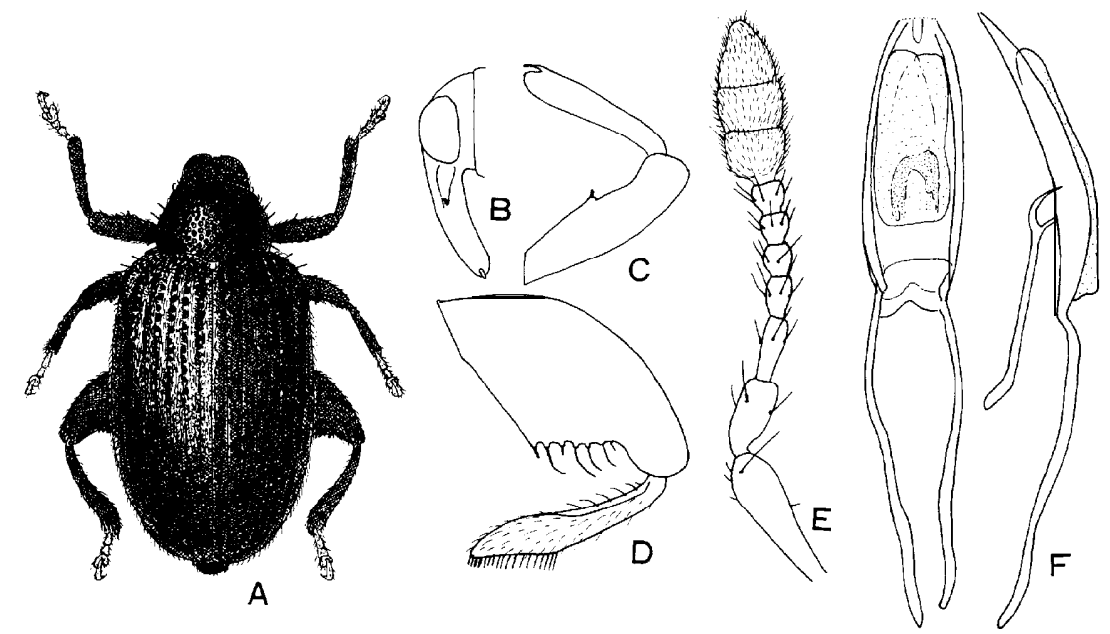

Fig. 30. Rhynchaenus (Orchestes)harunire sp. nov. A : Male. B : Male head. C : Fore leg. D : Hind leg. E: Antenna. F: Penis, apex broken.

v. 1977, K. Morimoto leg.

Paratypes: Same data as holotype, three females. Mt.Shinbo, N-Echigo, Niigata Pref., one female, 3. v. 1983, K. Baba leg.

Distribution : Japan (Honshu, Kyushu).

BIOLOGY : Adults were captured on the leaves of Ulmus davidiana (Harunire in Japanese) in Kumamoto.

The body form of this new species is intermediate between sanguinipes and horii.

\section{Rhynchaenus nitens sp. nov.}

Entirely black, shiny, with sparse brownish black pubescence on dorsal surface and sparse greyish fine hairs on ventral surface.

Head punctate ; forehead between eyes narrow at posterior third, then widening anteriorly. Rostrum 3.1 (male) or 5.3 (female) times as long as wide, dorsal bare space shiny and weakly carinate at base, which dilated to antennal insertion, densely punctate and coriaceous between scrobe and carina, densely punctate at sides leaving a narrow median bare space before antennal sockets. Antennae with scape as long as club and as long as first and second funicle combined, antennal insertion index 43.5 (male) or 35.0 (female).

Prothorax 1.32-1.34 times as wide as long, widest behind the middle, then scarcely narrowing posteriorly and weakly narrowing in front with moderate curve to the obsolete subapical constriction, disk reticulately punctate, often weakly coriaceous, without erect setae at sides.

Scutellum oval, coriaceous, with a few black pubescence.

Elytra 1.5 times as long as wide, widest in the middle, intervals smooth, shiny, each 


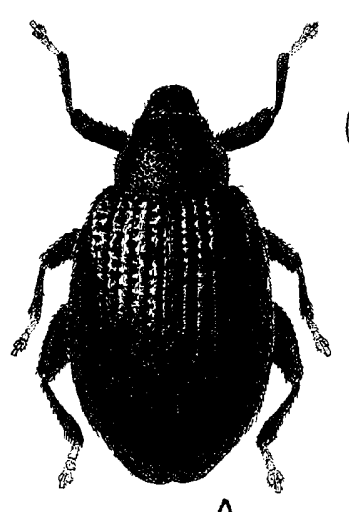

A
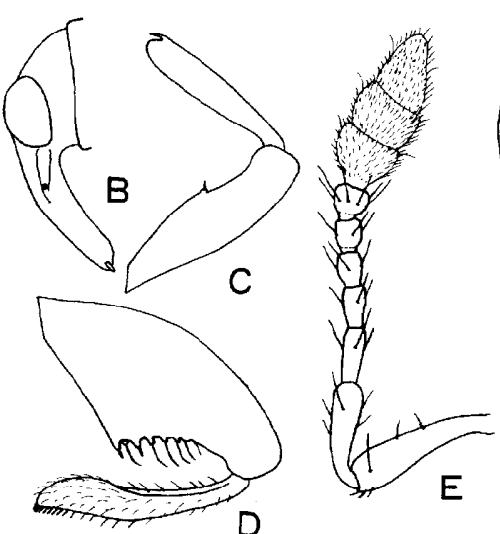

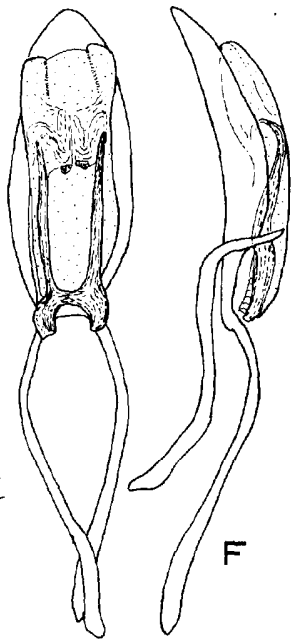

Fig. 31. Rhynchaenus (Orchestes) nitens sp. nov. A : Male. B : Male head. C : Fore leg. D : Hind leg. E: Antenna. F: Penis.

with two rows of sparse pubescences, striae much narrower than intervals, with distinct round punctures, which bearing a fine pubescence.

Fore coxal cavities and coxae contiguous. Underside punctate, weakly coriaceous at sides and fifth ventrite.

Fore and mid femora armed with spine. Hind femora 2.2 times as long as wide, with seven denticles, six long hairs and two long spines along hind margin.

Length : 2.9-3.3 mm.

Holotype male (Type No.2461, Kyushu Univ.), Daisen, Tottori Pref., 28. v. 1954, S. Kimoto leg.

Paratypes : Nikuchi, Miyagi Pref., one female, 2. vi. 1951, T. Watanabe leg. Yunomata, Ohata, Aomori Pref., one female, 16. vii. 1956, K. Morimoto leg. Mt. Myoko, Niigata Pref., one female, 18. v. 1976, K. Baba leg. Shimonegori, Obama City, Fukui Pref., one male, 6. v. 1979, H. Sasaji leg. Mt. Shigisan, Nara Pref., one male and two females, 3. v. 1956, K. Asakura leg. Same data as holotype, one female. Omogokei, Ehime Pref., one female, 3-4. v. 1958, Y. Miyatake leg.

Distribution : Japan (Honshu, Shikoku).

Biology : Unknown.

This new species is easily separable from the other Japanese species by the entirely black body, shiny and visibly bare dorsal surface, and oval elytra.

\section{Rhynchaenus mutabilis (Boheman)}

Orchestes mutabilis Boheman, 1843, Gen. Sp. Curc., VII(2): 372 (Dauria et Siberia orientalis). -Brisout, 1865, Ann. Soc. Ent Fr., (4) V : 268. -Faust, 1882, Deut. Ent. Zeit., XXVI : 282. -Kôno, 1930, Ins. Mats., V : 24 (Sakhalin, Hokkaido). 
Rhynchaenus mutabilis : Klima, 1935, Col. Cat., 145, Rhynchaeninae : 17. - Ter-Minassian, 1953, Ent. Oboz., XXXIII: 313. -Morimoto, 1962, Sci. Bull. Fac. Agr., Kyushu Univ., 19 : (Hokkaido, Sakhalin, Siberia). -Nakane, 1963, Icon. Ins. Jap. col. nat. ed., II : 378, pl. 189, fig. 18. -Morimoto, 1984, Col. Jap., IV : 296, pl. 58, fig. 17.

Head, rostrum excepting apex, prosternum, meso- and metathoraces, first ventrite, second ventrite excepting hind margin, and scutellum black, the remaining part reddish, elytra with black patch behind shoulder in the most reddish form, while in the most dark form, pronotum with broad transverse black band, elytra almost black excepting first interval, lateral and basal margins, and reddish patch a little behind the base between first and sixth striae, the latter patch continuous with sutural and basal reddish area internally, third ventrite excepting hind margin, fourth ventrite in the middle and fifth ventrite entirely black; in the intermediate form, elytra with two or three pairs of black patches.

Forehead between eyes a little wider than apex of scape. Rostrum 3.7 (male) or 3.9 (female) times as long as wide. Antennae with scape as long as first and second of funicle combined, antennal insertion index 38.5 (male) or 31.4 (female). Pronotum 1.4 times as wide as long, widest a little behind the middle, rounded at sides, subapical constriction weak at sides and obsolete on disk, disk transversely and weakly depressed at 1/4 from apex, and longitudinally depressed in the middle, the depression weak and often indistinct, with four to seven erect pale brown setae at each side. Elytra 1.65-1.70 times as long as wide, weakly flattened behind the base, intervals each with irregular two rows of greyish fine hairs.

Fore coxal cavities and coxae contiguous. Fore and mid femora armed with spine. Hind femora 2.1 times as long as wide, with seven denticles, four long setae, two long spines and nine small hairs along hind margin.

Length : $3.0-3.5 \mathrm{~mm}$.

Specimens exam ined : 23 exs. from Hokkaido (Ashoro, Ikeda, Osappe by Lake
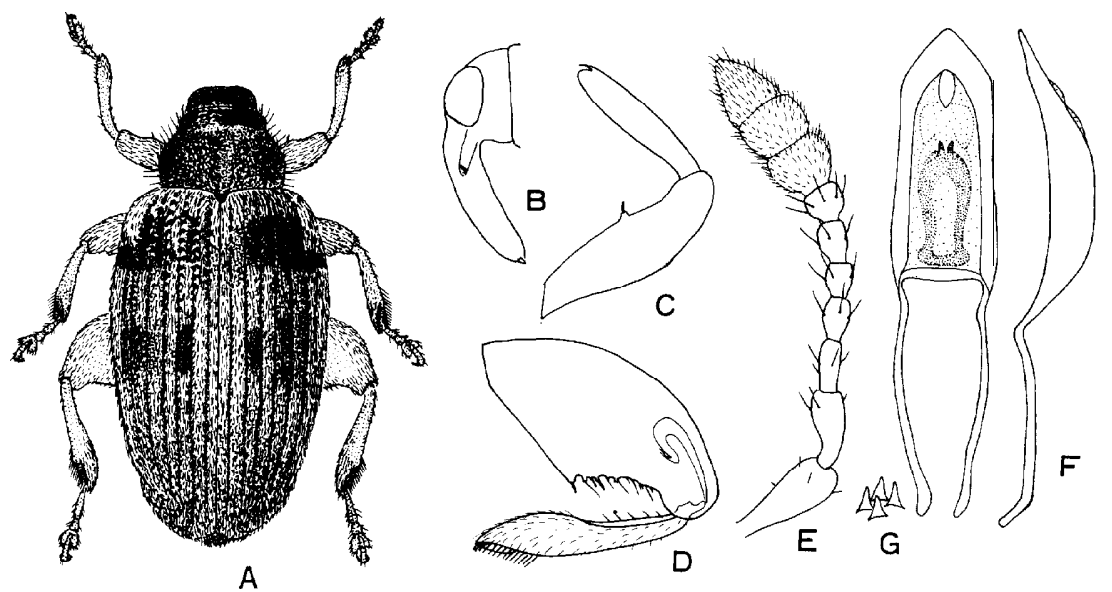

Fig. 32. Rhynchaenus (Orchestes) mutabilis (Boheman). A : Male. B : Male head. C: Fore leg. D : Hind leg. E : Antenna. F: Penis. G: Asperities of internal sac, enlarged. 
Kuccharo, Jozankei, Sapporo), and Aomori (Sanyoshi).

Distribution : Japan (Hokkaido, Honshu), Sachalin, and Siberia.

BIOLOGY: The adults and larvae attack the leaves of Ulmus davidiana and $U$. laciniata (Harunire and Ohyo in Japanese).

One female from Aomori, which is black with reddish antennae and legs, was collected at the same tree together with above mentioned reddish specimens. I hesitate to classify it to mutabilis at present, because of the bad condition of the single specimen.

\section{R hynchaenus hustachei Klima}

Orchestes puberulus Hustache, 1920, (nec Boheman, 1859), Bull. Mus. Hist. Nat. Paris, (6) : 633 (Kioto, Mt. Takao). -Kôno, 1930, Ins. Mats., V : 23.

Rhynchaenus Hustachei Klima, 1935, Col. Cat., 145, Rhynchaeninae: 15 (nom. nov. pro puberulus Hustache).

Rhynchaenus hustachei :Kôno, 1950, Icon. Ins. Jap., : 1270 (host). -Ter-Minassian, 1953, Ent. Oboz., XXX111:313. -Morimoto, 1962, Sci. Bull. Fac. Agr., Kyushu Univ., $19: 186(=$ croceus Marshall, Honshu, Shikoku, Kyushu). -Nakane, 1963, Icon. Ins. Jap. col. nat. ed., II : 378, pl. 189, fig. 19. -Morimoto, 1984, Col. Jap., IV : 296, pl. 58, fig. 15.

Rhynchaenus croceus Marshall, 1951, Mushi, 24 : 87 (Murozumi in Prov. Suwo).

Rusty red to rusty yellowish red, mesosternum, metasternum, metepisterna, basal two or three ventrites black; derm uniformly clothed with concolorous greyish brown fine hairs.

Forehead between eyes slightly narrower than apex of scape. Rostrum 3.0 (male) or 3.4 (female) times as long as wide, antennal insertion index 38.7 (male) or 37.5 (female). Antennae with scape a little longer than first and second of funicle combined. Pronotum 1.25-1.27 times as wide as long, rounded at sides, widest behind the middle, disk densely punctate and coriaceous, with a flattened area in the middle of the basal half, with four to seven erect yellowish brown setae at side. Scutellum subcordiform, punctate and coriaceous. Elytra 1.47-1.54 times as long as wide, intervals flat, rugulose, each with three irregular rows of fine hairs, striae narrow, each with a rows of fine hairs. Fore coxae contiguous or narrowly distant, fore coxal cavities contiguous. Fore and mid femora armed with spine. Hind femora 2.1 times as long as wide, with six to seven denticles, seven long hairs, two long spines and twelve short setae along posterior margin.

Length : 3.1-4.0 $\mathrm{mm}$.

Specimens examined : $\mathbf{5 5}$ exs. from Hokkaido (Ashoro, Is. Rishiri), Niigata (Kurokawa, Yamakumada, Shiunji, Is. Sado), Akita (Nishiki-mura), Chiba (Mt. Takago), Kyoto (Kibune), Osaka (Mt. Iwawaki), Hiroshima (Murozumi), Ehime (Omogokei), Fukuoka (Mt. Hiko, Kuroki), and Oita (Mt. Sobo).

Distribution : Japan (Hokkaido, Honshu, Is. Sado, Shikoku, Kyushu).

B IOlOgY: The larvae live in the galls made by aphids on the leaves of Alnus japonica (Hannoki in Japanese), and are not leaf-miners.

This species is easily recognized by the coloration and larger size. R.croceus is 


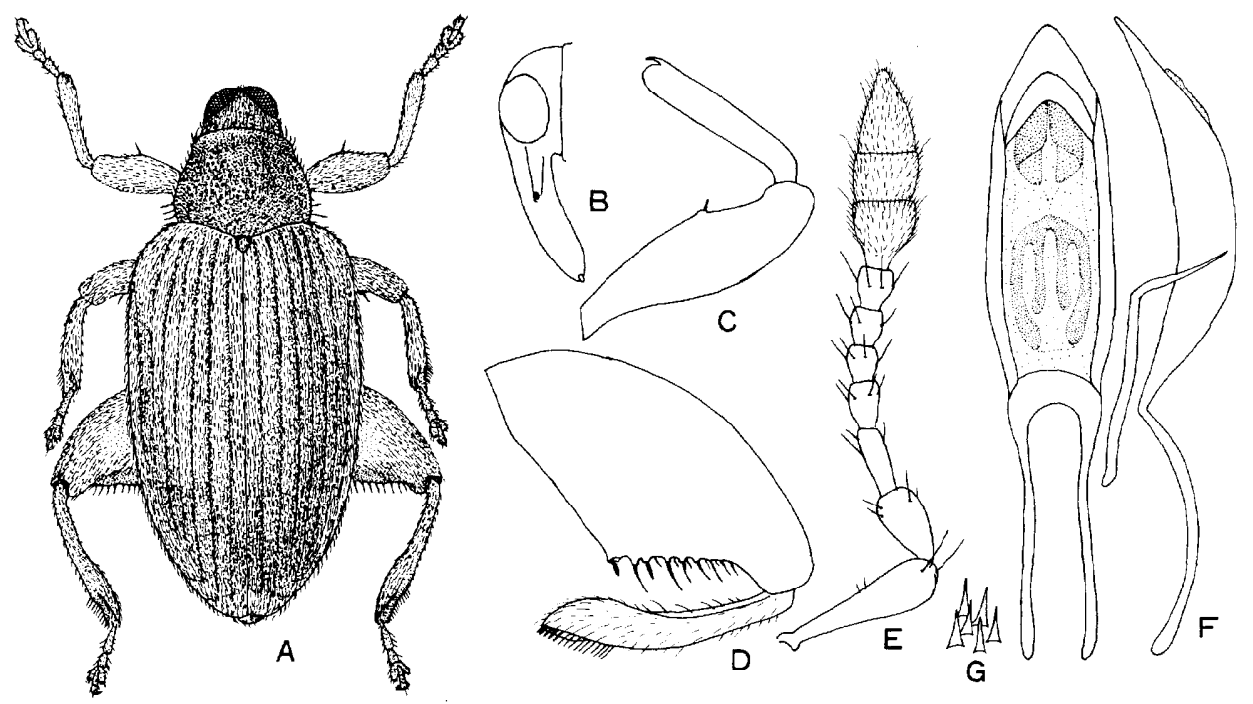

Fig. 33. Rhynchaenus (Orchestes) hustachei Klima. A : Male. B : Male head. C : Fore leg. D : Hind leg. E : Antenna. F : Penis. G: Asperities of internal sac, enlarged.

named for the teneral adults

\section{Rhynchaenus trunca tipennis sp. nov.}

Head, base of rostrum, thorax, and scutellum black, antennae and tarsi yellowish brown, fore and mid femora and tibiae reddish brown, elytra, venter and hind legs chestnut brown ; derm variegated with yellowish grey, white and brownish hairs; head with white hairs, which denser behind eyes, pronotum with yellowish grey hairs mixing brown ones, the former a little pronounced before scutellum and sides before the middle ; scutellum with a few dark fine hairs ; elytra with whitish hairs forming postscutellar patch and basal narrow band, and two vague bands, one at posterior third between outer margin of first interval and fifth stria, and the other just behind the apical margin, these bands often indistinct and evenly splashed with whitish hairs excepting the dorsomedian area, where brown fine hairs predominant ; lateral surface of thorax with dense white hairs, median area of metasternum and venter excepting margins of third to fifth ventrites very sparsely with greyish pubescence.

Head with dense punctures ; forehead between eyes linear. Rostrum 3.3 (male) or 3.5 (female) times as long as wide, with three rows of punctures on each side, coriaceous above scrobe. Antennae with scape shorter than first and second of funicle combined, antenna1 insertion index 20.0 (male) or 28.6 (female).

Pronotum 1.8 times as wide as long, widest at the base, strongly narrowed anteriorly with a moderate curve, subapical constriction obsolete, disk with dense punctures, coriaceous, with a few erect brown setae at sides. 

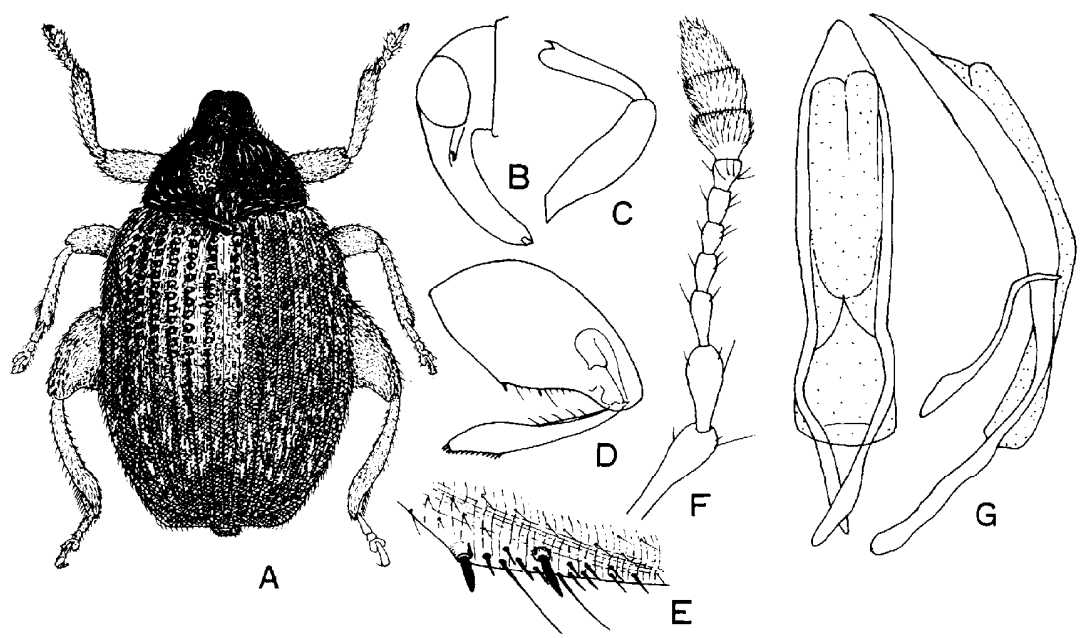

Fig. 34. Rhynchaenus (Orchestes)truncatipennis sp. nov. A : Male. B : Male head. C: Fore leg. D : Hind leg, E: Posterior part of hind femur, enlarged. F: Antenna. G: Penis.

Scutellum triangular, punctate, with a few dark fine hairs.

Elytra 1.32-1.36 times as long as wide, almost parallel-sided to apical third, conjoint apical margin truncate with a sutural incision, intervals flat, rugulose, striae narrow.

Fore coxae contiguous. Fore and mid femora armed with spine. Hind femora 1.95 times as long as wide, with two denticles, two long setae and two long spines along posterior margin.

Length : $2.0-2.1 \mathrm{~mm}$.

Holotype male (Type No. 2462, Kyushu Univ.), Izumi, Okinawa, 21. x. 1964, S. Miyamoto leg.

Paratypes : Kuroson, Kochi Pref., one male and one female, 29. iv. 1956, K. Morimoto leg. Mt. Yuwandake, Amami-Oshima, one male, 30. vii. 1963, J. L. Gressitt leg. Same data as holotype, 20 exs. Same locality as holotype, five exs., 22. iii. 1964, T. Shirôzu and Y. Miyatake leg. Yona, Okinawa, two females, 16-18. viii, 1958, T. Hidaka leg. ; one female, 18. x. 1963, S. Miyamoto. Mt. Omotodake, Ishigaki, one female, 14. x. 1963, Y. Hirashima leg.; one female, 16. iii. 1964. S. Kimoto leg.

Distribution : Japan (Shikoku, Amami-Oshima, Okinawa and Ishigaki Isls.).

This new species is characteristic in having broad pronotum and truncate elytra.

\section{R hynchaenus excellens (Roelofs)}

Orchestes excellens Roelofs, 1874, Ann. Soc. Ent. Belg., XVII : 164 (Japon).

Rhynchuenus excellens: Klima, 1935, Col. Cat., 145, Rhynchaeninae : 13. -Mer-Minassian, 1953, Ent. Oboz., XXX111:315. -Morimoto, 1962, Sci. Bull. Fac. Agr., Kyushu Univ., 19 : 186 (Kyushu). -Morimoto, 1984, Col. Jap., IV : 296, pl. 58, fig. 13.

Black, antennae and claws reddish brown, apical three ventrites and legs often 
dark reddish to blackish red, posterior margin of elytra often reddish, rarely whole body dark reddish brown; derm variegated with brownish, greyish and blackish hairs, pronotum with prostrate yellowish grey or brownish hairs forming a pair of vague patch before the middle, elytra with white postscutellar distinct patch, alternate intervals from the first with several blackish small patches, lateral pieces of mesothorax with dense stout brown hairs, the other parts of underside with fine brown hairs.

Head rugulose, punctate, coriaceous, with a median black carina, which extending anteriorly to the base of rostrum through linear forehead. Rostrum long, 4.5 (male) or 5.2 (female) times as long as wide. Antennae with scape a little longer than first and second of funicle combined, antennal insertion index 29.4 (male) or 20.0 (female). Pronotum 1.45-1.48 times as wide as long, widest a little before the base, narrowed in front with rather strong curve to weak subapical constriction, disk with dense small punctures, rugulose, coriaceous, longitudinally depressed in the middle, with six to eight erect dark brown setae at side. Scutellum as long as wide, rounded posteriorly, punctate, with broad hairs. Elytra 1.6-1.7 times as wide as pronotum, 1.4 times as long as wide, convex, subapical calli weak, transversely depressed behind the calli, intervals flat, rugulose.

Fore coxal cavities narrowly separated. Fore and mid femora armed with spine. Hind femora 2.13 times as long as wide, with seven to nine denticles, four to six long setae, four long spines and eight to ten short spines along the hind margin.

Length : $3.5-4.3 \mathrm{~mm}$.
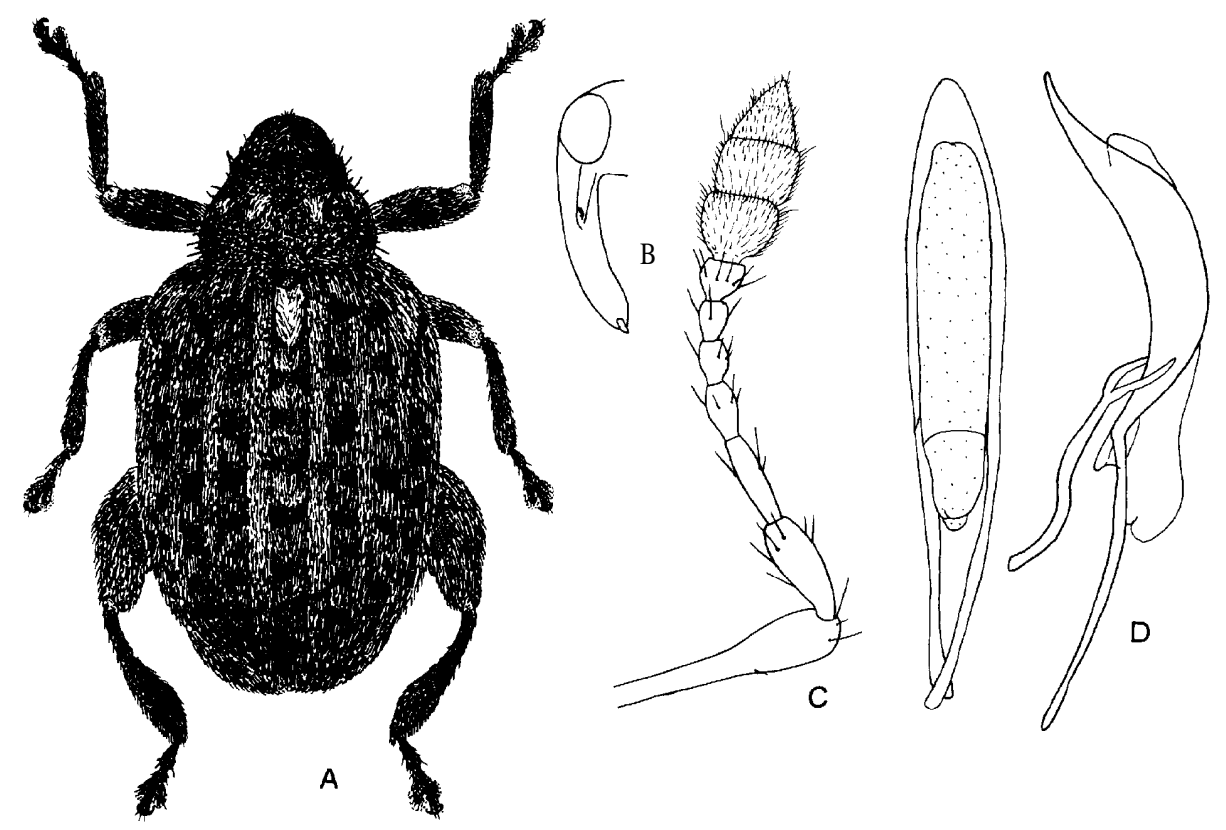

Fig. 35. Rhynchaenus(Orchestes) excellens (Roelofs). A : Male. B : Male head. C : Antenna. D : Penis. 
SpeCimens examined : Mt. Kiyosumi, Chiba Pref., one male and three females, 8. vi. 1963, K. Morimoto leg. Mt. Homan, Fukuoka Pref., one female, 31. v. 1957, H. Kamiya leg. Mt. Kumado, Fukuoka Pref., one female, 24. v. 1959, Y. Miyake leg.

Distribution: Japan (Honshu, Kyushu).

Biology : Unknown.

This is similar to irroratus (Kiesenwetter) and pilosus (Fabricius), both from Europe, but much larger and the elytra are more wider.

\section{Rhynchaenus japonicus (Hustache)}

O rchestes japonicus Hustache, 1920, Bull. Mus. Hist. Nat. Paris, (6) : 632 (Nakano pres Tokio).

Rhynchaenus japonicus : Klima, 1935, Col. Cat., 145, Rhynchaeninae : 15. -Ter-Minassian, 1953, Ent. Oboz., XXX111 :322. -Morimoto, 1962, Sci. Bull. Fac. Agr., Kyushu Univ., 19 : 186 (=excellens

Kôno, nec Hustache). -Nakane, 1963, Icon. Ins. Jap. col. nat. ed., II : 377, pl. 189, fig. 13.

-Morimoto, 1984, Col. Jap., IV : 296, pl. 58, fig. 14.

O rchestes excellens :Kôno, 1930, (nec Roelofs), Ins. Mats., V : 23.

Rhynchaenus excellens : Kôno, 1950, (nec Roelofs), Icon. Ins. Jap., 1270, fig. 3662.

Black, apex of rostrum, antennae and legs rusty red to brownish red ; derm covered with dense greyish brown and greyish stout hairs, elytra often with vague greyish band at apical fourth and with several bare small patches on alternate intervals ; lateral surface of thorax as densely hairy as elytra, ventral surface with sparse fine greyish hairs, which a little longer and denser at fifth ventrite.

Forehead between eyes slightly narrower than apex of scape. Rostrum 3.2 (male) or 4.2 (female) times as long as wide, punctate leaving impunctate median weak carina. Antennae with scape longer than first and second of funicle combined, antennal insertion index 36.7 (male) or 30.2 (female). Pronotum 1.35-1.38 times as long as wide, disk with dense small punctures, coriaceous, flattened in the middle of the basal half, each side with five to eight erect brownish grey setae. Scutellum oval. Elytra oblong-oval, 1.65-1.7 times as long as wide, subapical calli absent, alternate intervals slightly convex.

Fore coxal cavities contiguous, fore coxae narrowly distant. Fore and mid femora armed with spine. Hind femora 1.86 times as long as wide, with nine to ten denticles, five long setae, two long spines and about thirty short spines along posterior margin.

Length : $3.8-4.3 \mathrm{~mm}$.

Specimens examined : 91 exs. from Hokkaido (Ashoro), Iwate (Ryugamori, Morioka, Ichinohe) Akita (Lake Tazawako), Niigata (Sado), Gumma (Shinto-mura), Saitama (Ogose), Tokyo (Inada-Noborito), Kyoto (Kurama, Katsuragawa), and Fukuoka (Shikanoshima).

DistRIBUtion: Japan (Hokkaido, Honshu, Kyushu).

Biology: The adults and larvae attack the young leaves of Quercus acutissima, Q. serrata and Q. dentata (Kunugi, Konara and Kashiwa in Japanese).

This is also similar to irroratus (Kiesenwetter) and pilosus (Fabricius), but the legs are rusty red. 

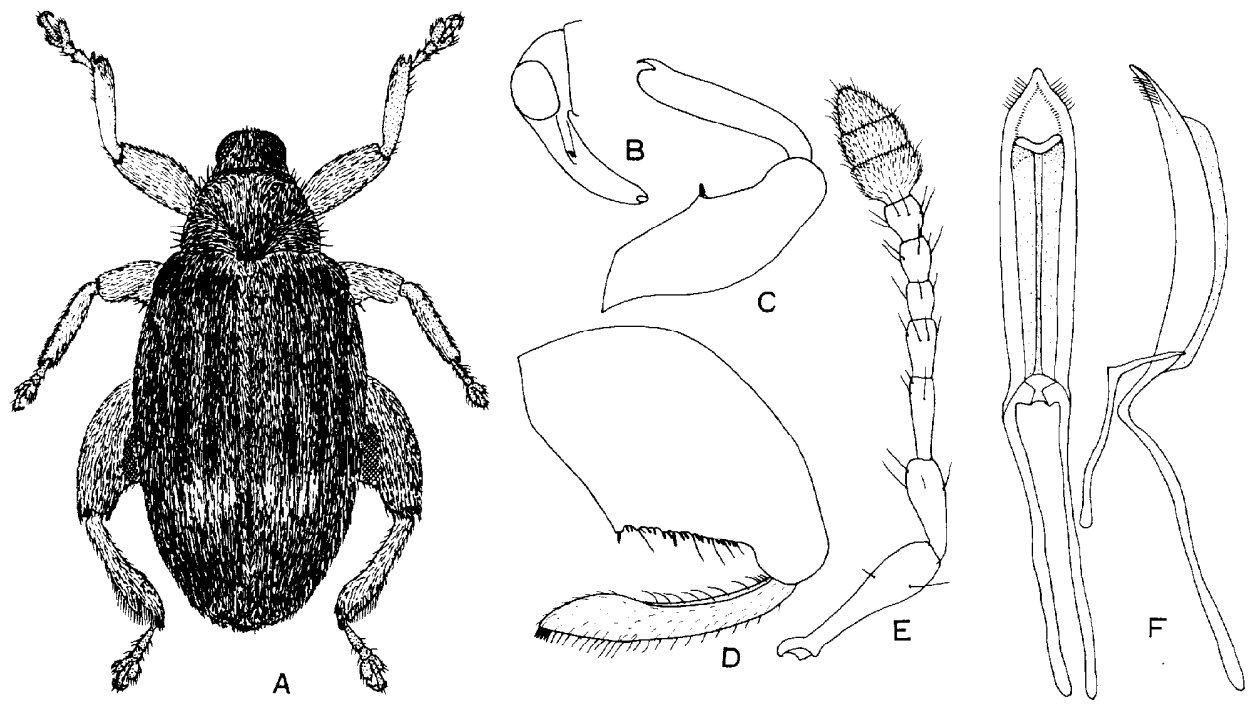

Fig. 36. Rhynchaenus (Orchestes) japonicus(Hustache). A : Male. B : Male head. C : Fore leg. D : Hind leg. E : Antenna. F : Penis.

\section{R hynchaenus nomizo (Kôno)}

Orchestes nomizo Kôno, 1930, Ins. Mats., V :26 (Sakhalin, Sapporo, Chuzenji, Hachioji).

Rhynchaenus nomizo :Klima, 1935, Col. Cat., 145, Rhynchaeninae : 17. -Ter-Minassian, 1953, Ent. Oboz., XXX111:315. - Voss, 1958, Decheniana, Beihefte 5 : 106 (China : Fukien). -Morimoto, 1962, Sci. Bull. Fac. Agr., Kyushu Univ., 19: 186 (Hokkaido, Honshu, Sakhalin, China). -Nakane, 1963, Icon. Ins. Jap. col. nat. ed., II : 378, pl. 189, fig. 16. -Yokomizo, 1976, Shinrin Boeki, 25(7): 4 (host). -Kobayashi, 1977, Pests of Garden Trees, II : 137 (biology). -Morimoto, 1984, Col. Jap., IV : 296, pl. 58, fig. 21.

Black, antennae reddish, tarsi dark reddish brown ; derrn mottled with blackish and greyish hairs, the latter forming distinct postscutellar patch and two bands on elytra as Fig. 37, the bands often indistinct ; undersurface sparsely clothed with fine' dark brown hairs, lateral surface of thorax with sparse greyish hairs.

Forehead between eyes linear. Rostrum 3.6 (male) or 4.1 (female) times as long as wide, almost bare. Antennae with scape as long as first of funicle, antennal insertion index 22.2 (male) or 24.1 (female). Pronotum 1.5 times as wide as long, widest at basal third, disk with dense punctures and coriaceous, with a shallow median longitudinal sulcus, with one or two erect black spines near hind angle at side. Scutellum oval, punctate coriaceous. Elytra 1.51-1.53 times as long as wide, shiny, each interval with two rows of minute black hairs, striae as wide as intervals on basal half.

Fore coxal cavities contiguous, fore coxae often narrowly distant. Fore and mid femora armed with seta. Hind femora 2.2 times as long as wide, with ten denticles, three to four long setae, two long spines and sixteen to twenty short spines along 

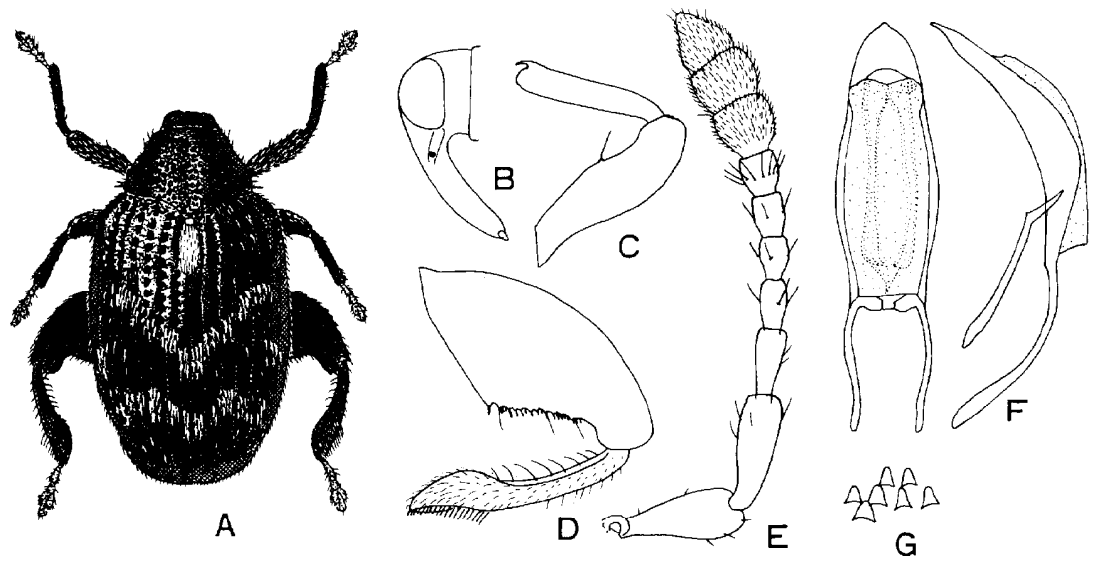

Fig. 37. Rhynchaenus (Orchestes) nomizo(Kôno). A : Male. B : Male head. C: Fore leg. D : Hind leg. E: Antenna. F: Penis. G : Asperities of internal sac, enlarged

posterior margin.

Length : 2.5-2.8 $\mathrm{mm}$.

Specimens eXAmined : 102 exs. from Hokkaido (Bifuka, Nibushi, Mt. Meakandake, Ashoro, Engaru, Nukabira), Aomori (Ohata, Mt. Hakkoda), Yamagata (Atsumi Spa.), Niigata (Kurokawa, Shiroike, Nakajo, Sasagamine, Renge Spa, Mt. Myoko, Mt. Hishigatake, Asakai, Mikuni-toge), Ishikawa (Mt. Hakusan), Tochigi (Nikko, Mt. Keichozan), Nagano (Wada-toge, Shirahone, Mt. Ontake, Karuizawa, Kamikochi), Fukui (Koike), Gifu, and Tottori (Mt. Daisen).

Distribution: Japan (Hokkaido, Honshu), and Sakhalin.

Biology: The larvae and adults attack the young leaves of Betula platyphylla var. japonica (Shirakanba in Japanese). Dr. Kuroko reared an adult from the miner of Corylus sieboldiana var. manchurica (Ootsunohashibami in Japanese).

\section{Rhynchaenus villosus sp.nov.}

Black, apex of rostrum, antennae and tarsi reddish ; derm mottled with blackish and greyish hairs, the latter forming distinct postscutellar patch and two bands on elytra as Fig. 38, the pattern is similar to nomizo, but black hairs longer, erect setae at side margins of pronotum and elytra conspicuous, undersurface with greyish hairs, which are sparser and finer on metasternum and venter.

Head punctate, finely coriaceous, with sparse greyish hairs on vertex, forehead between eyes linear. Rostrum 4.0 (male) or 4.3 (female) times as long as wide, dorsal surface shiny, impunctate, lateral surface roughly punctate, coriaceous, hairy above scrobe. Antennae with scape as long as first of funicle, antennal insertion index 25.0 (male) or 22.21 (female).

Pronotum 1.5 times as wide as long, widest a little before the base, rapidly 
narrowing anteriorly with a weak curve, subapical constriction weak, disk convex, with large punctures, finely coriaceous, each side with a few erect black setae near the base and several recumbent setae before the middle.

Scutellum circular, punctate, coriaceous.

Elytra 1.32-1.35 times as long as wide, intervals as wide as striae, convex, rugulose, with a row of long black hairs, striae with large punctures, which bearing fine hairs, the septa of punctures a little lower than intervals.

Fore coxal cavities contiguous, fore coxae narrowly distant. Sternites of thorax and first two ventrites with strong punctures, rugulose and coriaceous on apical three ventrites. Fore and mid femora armed with spine. Hind femora twice as long as wide, with ten to eleven denticles, three long hairs, two long spines, eleven to thirteen short spines along posterior margin.

Length : 2.1-2.4 mm.

Holotype male (Type No. 2463, Kyushu Univ.), Tatsudayama, Kumamoto City, 13. vi. 1977, K. Morimoto leg.

Paratypes : Same locality as holotype, 57 exs. 3. v-11. vii. 1977, K. Morimoto, Y. Imakiire and N. Yoshida leg. Hakone, Kanagawa Pref., one male, 26. vi. 1961, K. Morimoto leg. Mt. Murakuni, Takefu City, Fukui Pref., one female, 22. vii. 1956, Y. Murakami leg. Mt. Wakasugi, Fukuoka Pref., one female, 18. v. 1958, H. Kamiya leg.

Distribution : Japan (Honshu, Kyushu).

Biology : Host tree is unknown. The weevils were captured by the Malaise trap set in the campus of the Kyushu Branch Station, Forest Research Institute, Tatsu dayama, Kumamoto.

The coloration and hairy pattern are similar to nomizo, but elytra are shorter,
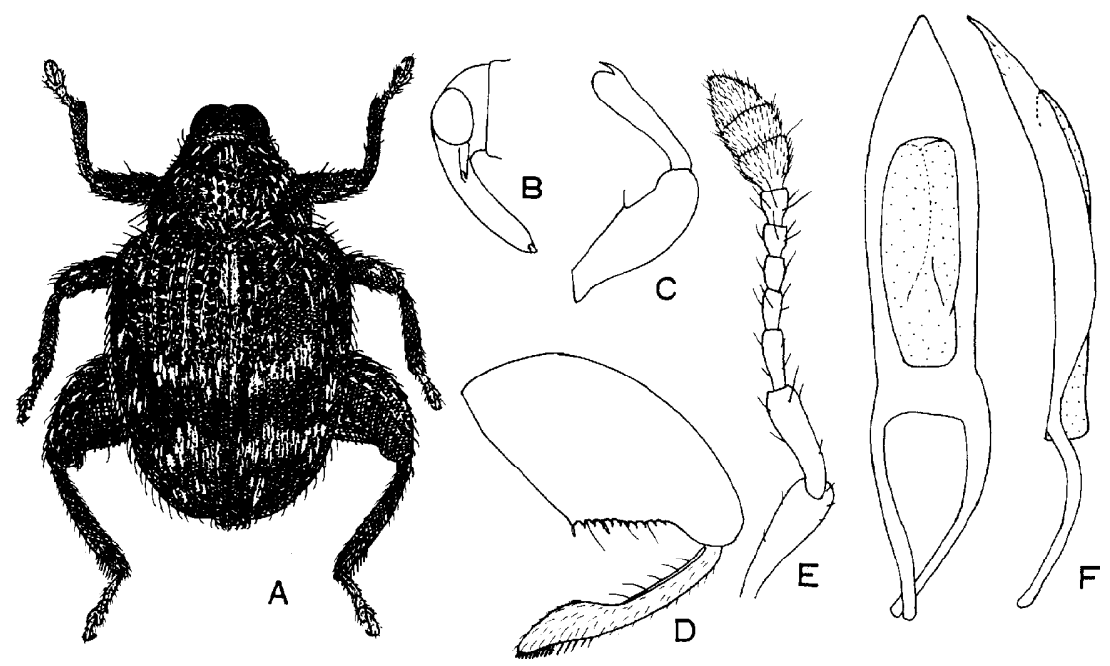

Fig. 38. Rhynchaenus (Orchestes) villosus sp. nov. A : Male. B : Male head. C : Fore leg. D : Hind leg. E : Antenna. F : Penis. 
hairs are more shaggy, and median sulcus on pronotum is absent.

\section{R hynchaenus takabayashii (Kôno)}

Orchestes takabayashii Kôno, 1930, Ins. Mats., V : 25 (Takao).

Rhynchaenus Takabayashii: Klima, 1945, Col. Cat, 145, Rhynchaeninae : 31.

Rhynchaenus takahayashii : Morimoto, 1962, Sci. Bull. Fac. Agr., Kyushu Univ., 19 : 187 (Honshu,

Shikoku, Kyushu). -Morimoto, 1984, Col. Jap., IV : 296, pl. 58, fig. 12.

Orchestes jota:Kôno, 1930, (nec Fabricius), Ins. Mats., V : 25 (Sapporo, Jozankei).

Rhynchaenus jota: Morimoto, 1959, (nec Fabricius), Enum. Ins. Mt. Hiko. II : 84 (Mt. Hiko).

-Ichihashi, 1956, Shin Konchu, 9(3): 47 (Mie).

Black, antennae and tarsi reddish brown; derm covered with brownish black fine and whitish hairs, the latter forming two longitudinal stripes on pronotum, transverse narrow band at the base and postscutellar patch on elytra, often the stripes on pronotum absent, often whitish hairs scattered on elytra in the specimens from northern Honshu ; lateral surface with sparse white hairs, which more or less denser at sides of head behind eyes and on mesepimera ; metasternum excepting sides and venter with sparse fine greyish hairs.

Forehead between eyes linear. Rostrum $\mathbf{4 . 0}$ (male) or $\mathbf{4 . 7}$ (female) times as long as wide, with median carina. Antennae with scape shorter than first and second of funicle combined, club almost as long as first of funicle, antennal insertion index 26.7 (male) or 23.5 (female). Pronotum 1.54-1.59 times as wide as long, widest at posterior fourth, disk reticulately punctate and coriaceous, with shallow or indistinct median sulcus. Elytra 1.42-1.48 times as long as wide, intervals rugulose, coriaceous, with irregular three rows of fine hairs, striae narrower than intervals, each puncture bearing a fine hair.
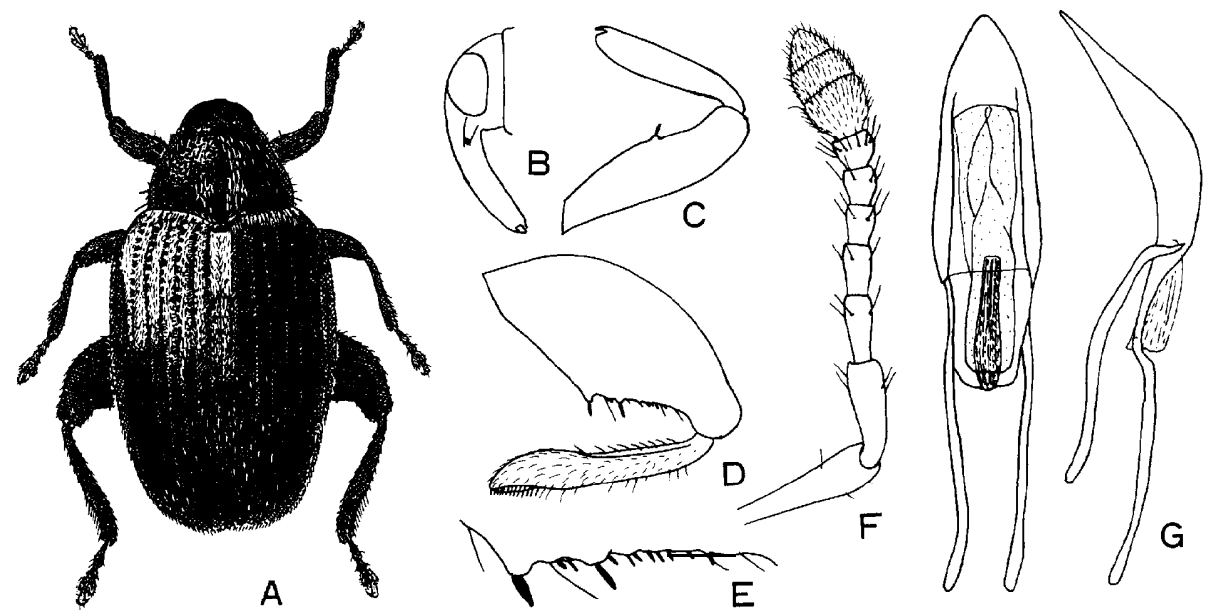

Fig. 39. Rhynchaenus (Orchestes) takubayashii (Kôno). A : Male. B : Male head. C : Fore leg. D : Hind leg. E: Posterior margin of hind femur, enlarged. F: Antenna. G: Penis. 
Fore coxal cavities contiguous, fore coxae narrowly distant. Fore and mid femora armed with spine. Hind femora 2.24 times as long as wide, with four denticles, three long setae, two long spines and ten short spines along hind margin.

Length : 2.3-2.9 mm.

Specimens examinen: 132 exs. from Hokkaido (Ashoro, Mt. Meakandake, Nopporo, Wakkanai), Aomori (Oohata), Iwate (Morioka), Akita (Kuromori-toge, Mt. Komagatake), Niigata (Kurokawa, Tsuchizawa, Sasagamine, Mt. Hishigatake), Miyagi (Matsushima-cho), Chiba (Mt. Takago), Kanagawa (Tsukui, Yugawara) Nagano (Shirahone, Mt. Asama), Ishikawa (Suzu), Fukui (Mt. Murakuni), Kyoto (Kibune), Mie (Mt. Nonobori, Mt. Oike), Tottori (Mt. Daisen), Fukuoka (Mt. Hiko, Inunaki, Mt. Homan), Oita (Mt. Kuju, Handakogen), Kumamoto (Kikuchisuigen), and Tsushima.

Distribution: Japan (Hokkaido, Honshu, Shikoku, Kyushu, Tsushima).

Biology: The adults and larvae attack the leaves of Quercus salicina, Q. serrata, Q. acutissima and Castanea crenata (Urajirogashi, Konara, Kunugi and Kuri in Japanese). New adults appear in June.

This is very close to jota (Fabricius), but separable from it by the following points :

R. takabayashii : Elytra more convex, with greyish band along basal margin, postscutellar patch about three times as long as wide. Rostrum with median carina or ridges.

R. jota: Elytra less convex, blackish with postscutellar white patch, which twice as long as wide. Rostrum not carinate but flat dorsally.

The specimens identified by Kôno, 1930, Morimoto, 1959, and Ichihashi, 1956, as jota are nothing but the specimens of takabayashii without whitish hairs on pronotum. These blackish individuals are also similar to amurensis (Faust).

The aedeagus of takabayashii is characteristic in having pigmented sharp internal ridge at the base,

\section{Rhynchaenus variegatus (Roelofs)}

Orchestes variegatus Roelofs, 1874, Ann. Soc. Ent. Belg., XVII : 166 (Japon).

Orhcestes spinosus Hustache, 1920, Bull. Mus. Hist. Nat. Paris, (6) : 634 (Mt. Takao, Gifu). -Kôno, 1930, Ins. Mats., V :27. Syn. nov.

Rhunchaenus spinosus: Klima, 1935, Col. Cat., 145, Rhynchaeninae : 30. -Ter-Minassian, 1953, Ent. Oboz., XXXIII : 321. -Morimoto, 1962, Sci. Bull. Fac. Agr., Kyushu Univ., 19 : 187 (Honsu, Shikoku, Kyushu). -Nakane, 1963, Icon. Ins. Jap. col. nat. ed., II : 378, pl. 189, fig. 15. -Morimoto, 1984, Col. Jap., VI : 296, pl. 58, fig. 18 .

Rostrum and underside black, vertex, antennae, pronotum, elytra and legs reddish brown to rusty red, elytra with two dark brown bands, anterior band narrow, often obsolete, posterior band broad, often two bands confluent and occupying basal twothirds of elytra ; derm clothed with yellowish grey and brownish black hairs, the former on head, pronotum and reddish areas of elytra and a little denser at the base and apex of third intervals, the brownish black fine hairs covering the dark brown patches on elytra; lateral surface of thorax with yellowish grey hairs as dense as those 

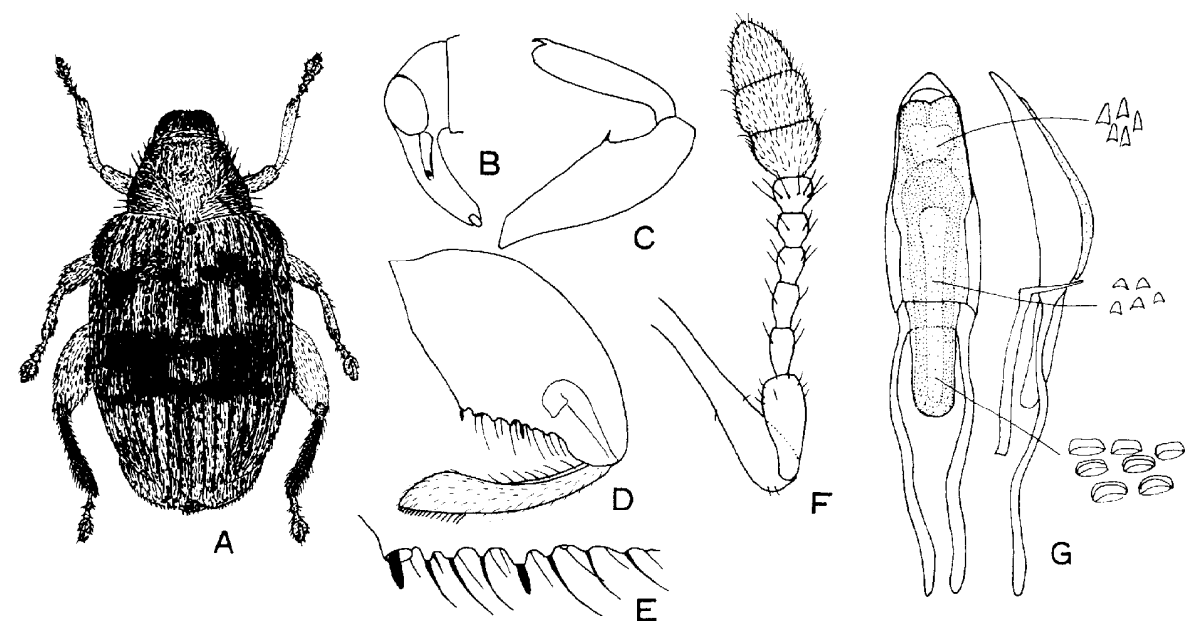

Fig. 40. Rhynchaenus (Orchestes) variegatus (Roelofs). A : Male. B : Male head. C : Fore leg. D : Hind leg. E : Posterior margin of hind femur, enlarged. F: Antenna. G: Penis.

on pronotum, metasternum excepting sides and venter with sparse minute greyish hairs.

Forehead between eyes linear. Rostrum 4.3 times as long as wide in both sexes, punctate and coriaceous behind antennal sockets and at sides leaving narrow dorsal bare space before antennal sockets. Antennae with scape long, longer than first three segments of funicle combined, antennal insertion index 42.3 (male) or 40.0 (female). Pronotum 1.38-1.50 times as wide as long, widest at the base, disk with shallow punctures, coriaceous, without median sulcus, with one to three erect blackish setae at side near the base. Scutellum black, small, coriaceous. Elytra 1.42-1.45 times as long as wide, third interval slightly raised at base, coriaceous before the middle.

Fore coxal cavities and coxae contiguous. Fore and mid femora armed with spine. Hind femora two times as long as wide, with eight to nine denticles, six long setae and two long spines along hind margin.

Length : 2.7-2.9 $\mathrm{mm}$.

Specimens examined: 59 exs. from Hokkaido (Wakkanai), Aomori (Oohata), Yamagata (Mt. Zao), Niigata (Asakai), Fukui (Koike), Kyoto (Mt. Kurama), Wakayama (Mt. Gyojayama), Kochi (Jinzenji, Tosayama, Kuroson), Fukuoka (Hirao, Mt. Joyama), Nagasaki (Mt. Kompira, Mt. Iwaya, Mt. Atago), Kumamoto (Tomioka), Kagoshima (Kaseda), and Tsushima.

Distribution : Japan (Hokkaido, Honshu, Shikoku, Kyushu, Tsushima).

BIology : The adults were captured on Quercus glauca and Castanopsis cuspidata (Arakashi and Tsuburajii in Japanese).

The ground colour of elytra is variable as stated above, and spinosus is synonymous with variegatus. Kôno, 1930, erroneously synonymized variegatus with mutabilis. I have compared both types. 

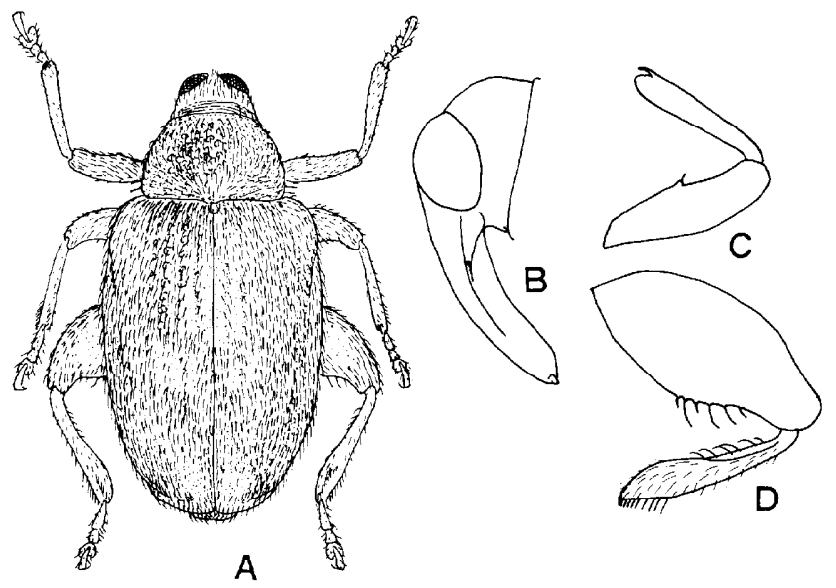

Fig. 41. Rhynchaenus (Orchestes) hidakai sp. nov. A: Female. B: Female head. C: Fore leg. D: Hind leg.

\section{Rhynchaenus hidakai sp. nov.}

Rusty red, derm clothed with concolorous yellowish grey prostrate hairs, metasternum and first to fourth ventrites very sparsely clothed with fine greyish hairs.

Head with small dense punctures, coriaceous, with a median bare carina, forehead between eyes linear for a short distance at basal third, then weakly widening anteriorly. Rostrum 2.7 times as long as wide, with a weak median carina, with a row of punctures on dorsolateral edge, sulcus at side extending anteriorly from scrobe, and a row of large punctures on ventrolateral edge of each side, each puncture bearing greyish hair. Antennae with scape as long as club, as long as first and second of funicle combined, antennal insertrion index 25.

Pronotum 1.5 times as wide as long, widest a little before the base, subapical constriction obsolete, disk with shallow punctures, coriaceous, without median sulcus, with two erect yellowish brown setae at each side near the base.

Scutellum oval, coriaceous, with hairs as on elytra.

Elytra 1.53 times as long as wide, intervals flat, finely rugulose, coriaceous, each with two rows of hairs, the hair as long as the width of interval, striae with shallow punctures, the septa as high as intervals, each puncture bearing hair similar to that on interval.

Fore coxal cavities and coxae contiguous. Metasternum shiny, with sparse fine punctures excepting anterior and lateral margins, with a median longitudinal depression, metepisternum coriaceous, with irregular three rows of hairs. First to fourth ventrites shiny, with scattered fine punctures, fifth ventrite and posterior margins of third and fourth ventrites coriaceous and with longer hairs. Fore and mid femora armed with spine. Hind femora 2.2 times as long as wide, with six denticles, four long 
setae and two long spines along hind margin.

Male : Unknown.

Length : $1.8 \mathrm{~mm}$.

Holotype female (Type No. 2464, Kyushu Univ.), Obama, Nagasaki Pref., 25. ii. 1960, T. Hidaka leg.

Distribution : Japan (Kyushu).

Biology : One female was captured by sifting the moss.

This new species is easily recognized by the small size, entirely rusty red coloration, immaculate hairy covering, and weak punctures on pronotum and elytra.

\section{Rhynchaenus heritierae sp. nov.}

Yellowish red, rostrum, antennae and legs paler; dorsal surface mottled with ochreous stout and brownish fine hairs, the latter forming vague median patch on pronotum, and three bands on elytra, the basal band interrupted by second and third intervals and extending laterally to sixth intervals, the median band between sixth intervals interrupted by first intervals, subapical band between fifth intervals prolonged anteriorly at first and fifth intervals ; lateral surface as densely hairy as those on elytra, metasternum and venter sparsely with fine hairs, which a little denser at sides and on fifth ventrite.

Head with small punctures, coriaceous, without median carina ; forehead between eyes linear at posterior third, then rapidly widening anteriorly. Rostrum 3.1 (male) or 3.4 (female) times as long as wide, with a weak median carina at base, which continuous to a fine median sulcus anteriorly, coriaceous before eyes, finely punctate at sides, sparsely with yellowish brown fine hairs at sides. Antennae with scape a little longer than first to third segments of funicle combined, club as long as scape, antenna1 insertion index 33.3 (male) or 30.8 (female).

Pronotum 1.65-1.74 times as wide as long, widest at base, narrowed in front with weak curve, subapical constriction obsolete; disk densely with small shallow punctures, coriaceous, not sutcate, without erect spines at side.

Scutellum oval, coriaceous, as densely hairy as on pronotum.

Elytra 1.3-1.4 times as long as wide, intervals weakly convex, finely rugulose, coriaceous, second interval a little narrower than third, each with three irregular rows of hairs, striae narrow, with oblong punctures.

Fore coxal cavities linearly distant. Meso- and metasterna and venter with small shallow punctures. Metasternum with a brown median line.

Fore and mid femora armed with spine. Hind femora 1.9 times as long as wide, with five to seven weak denticles, four long setae and three long spines along posterior margin.

Length : 2.7-2.9 mm.

Holotype male (Type No. 2465, Kyushu Univ.), Inaba, Iriomote Is., 10. iii. 1964, Y. Miyatake leg.

Paratypes : Same data as holotype, six males and eight females. 

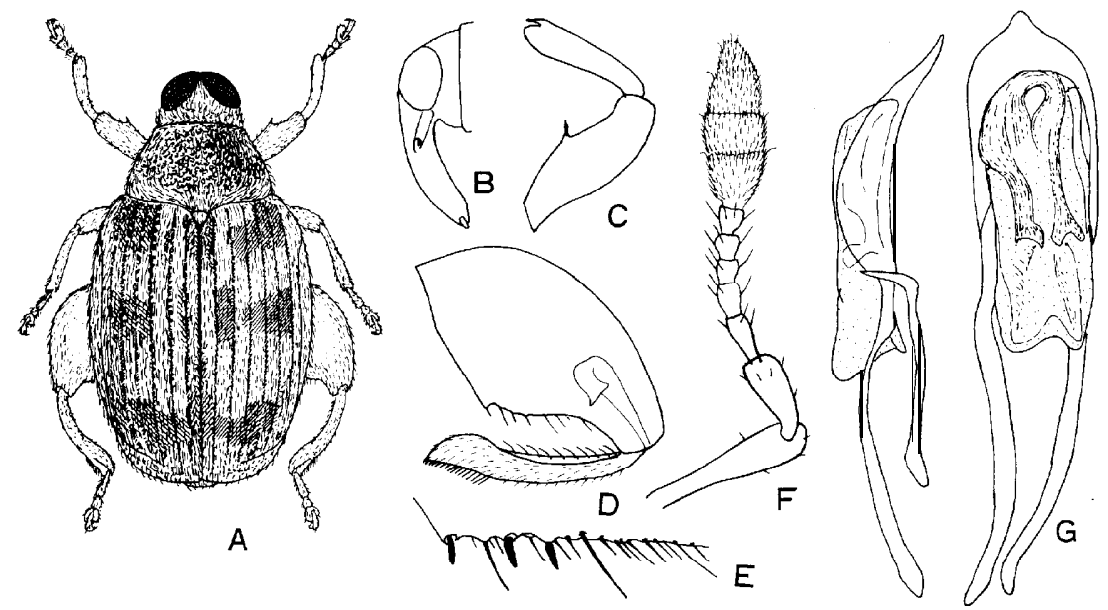

Fig. 42. Rhynchaenus (Orchestes) heritierae sp. nov. A: Male. B: Male head C : Fore leg. D: Hind leg. E : Posterior margin of hind femur, enlarged. F: Antenna. G : Penis.

Distribution : Japan (Iriomote I.).

BIology : The adults were captured on Heritieralittoralis (Sakishimasuoonoki in Japanese).

This new species is characteristic in the coloration, robust rostrum, broad pronotum, and unarmed sides of pronotum and eiytra with erect setae.

\section{Rhynchaenus dorsoplanatus (Roelofs)}

Orchestes dorso-planatus Roelofs, 1874, Ann. Soc. Ent. Belg., XVII : 167 (Japon).

Orchestes dorsoplanatus: Faust, 1882, Deut. Ent. Zeit., XXVI : 281. -Kôno, 1930, Ins. Mats., V : 23. Rhynchaenus dorsoplanatus : Klima, 1935, Col. Cat., 145, Rhynchaeninae :12. -Ter-Minassian, 1953,

Ent.Oboz., XXX111 : 314. - Voss, 1958, Decheniana, Beihefte 5 : 106 (China : Fukien). -Morimoto, 1962, Sci. Bull. Fac. Agr., Kyushu Univ., 19: 185 (Honshu, Shikoku, Kyushu, China). -Nakane, 1963, Icon. Ins. Jap. col. nat. ed., II : 377, pl. 189, fig. 12. -Morimoto, 1984, Col. Jap., IV : 296, pl. 58, fig. 16.

Rusty red, meso- and metathorax, and lateral and apical margins of elytra dark reddish ; derm clothed with dense prostrate yellowish grey and black suberect hairs; pronotum with a pair of black fascicles before the middle ; elytra with two pairs of conspicuous black fascicles on third and fifth intervals at subapical calli formed of posteriorly directing black bristles, intervals exterior from fifth and posterior area behind calli with many black small patches formed or black hairs, and dorsal area on first and third intervals with a few black small patches, basal margin between sixth intervals with sparse suberect black bristles; lateral and undersides with dense yellowish grey hairs.

Head with a fine median carina; forehead between eyes linear at basal third for 


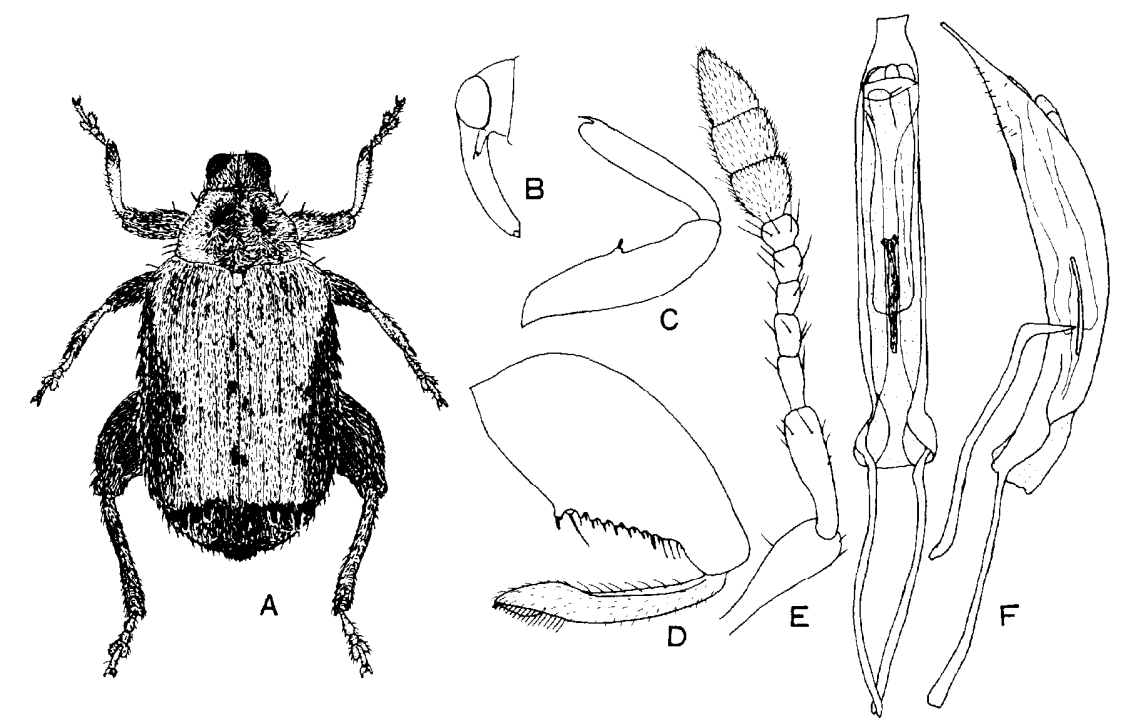

Fig. 43. Rhynchaenus(Orchestes) dorsoplanatus (Roelofs). A : Male. B : Male head. C: Fore leg. D : Hind leg. E: Antenna. F: Penis.

a short distance, then dilated anteriorly. Rostrum 3.9 (male) or 4.1 (female) times as long as wide, carinate at base, coriaceous above scrobes, punctate at sides. Antennae with scape a little longer than first of funicle, antennal insertion index 26.7 (male) or 30.3 (female). Pronotum 1.5 times as wide as long, widest at base, disk with a pair of swellings before the middle, with a weak median sulcus, each side armed with four to seven erect setae. Scutellum as densely hairy as on the base of pronotum. Elytra 1.4 1.5 times as long as wide, flat between fifth intervals, weakly depressed behind the base, subapical calli distinct.

Fore coxal cavities and coxae contiguous. Fore and mid femora armed with spine. Hind femora ' 2.1 times as long as wide, with ten denticles, three long setae, eight long spines and twelve to fourteen short spines along hind margin.

Length : 2.7-3.3 $\mathrm{mm}$.

Specimens examined : 32 exs. from Gifu (Kinkazan), Kyoto (Kibune), Kochi(Jinzenji, Kuroson), Fukuoka (Mt. Joyama, Mt. Korasan), Nagasaki (Mt. Kompira), Miyazaki (Miyazaki), Kagoshima (Iso), Tsushima, Tokara-Nakanoshima, and Taiwan (Fenchi$\mathrm{hu})$.

Distribution : Japan (Honshu, Shikoku, Tsushima, Tokara-Nakanoshima), Taiwan, and China (Fukien).

Biology : The adults were captured on the leaves of Castanopsis cuspidata (Tsuburajii in Japanese).

The swellings on pronotum, distinct calli and fascicles on elytra are characteristic of this species. 


\section{R hynchaenus trif ascia tus sp. nov.}

Black, tarsi reddish brown; derm mottled with greyish and black hairs, head with sparse greyish hairs and with long erect black setae at side and anterior margins, pronotum with many black recumbent setae on disk and erect setae at sides, and with sparse greyish prostrate hairs at dorso-lateral areas, scutellum visibly black, elytra with conspicuous yellowish postscutellar patch, and three greyish bands, femora variegated with greyish and black hairs, underside with greyish hairs, which being finer on metasternum and venter.

Head punctate, rugulose, coriaceous, median carina indistinct ; forehead between eyes much narrower than apex of scape. Rostrum 3.9 (male) or 4.1 (female) times as long as wide, with a median carina at base, with three rows of punctures at side leaving narrow impunctate median line dorsally. Antennae with club as long as scape and as long as first and second of funicle combined, antennal insertion index 29.7 (male) or 34.2 (female).

Pronotum 1.40-1-45 times as wide as long, widest a little before the base, strongly rounded at sides, subapical constriction weak, strongly convex dorsally, with a median longitudinal sulcus, which divides the swelling into a pair.

Scutellum oval, coriaceous, with a few of blackish fine hairs.

Elytra 1.26-1.29 times as long as wide, with distinct subapical calli, of which the posterior margins transversely depressed, weakly depressed behind the base between third intervals, intervals flat, coriaceous, rugulose, striae much narrower than intervals, with deep punctures.
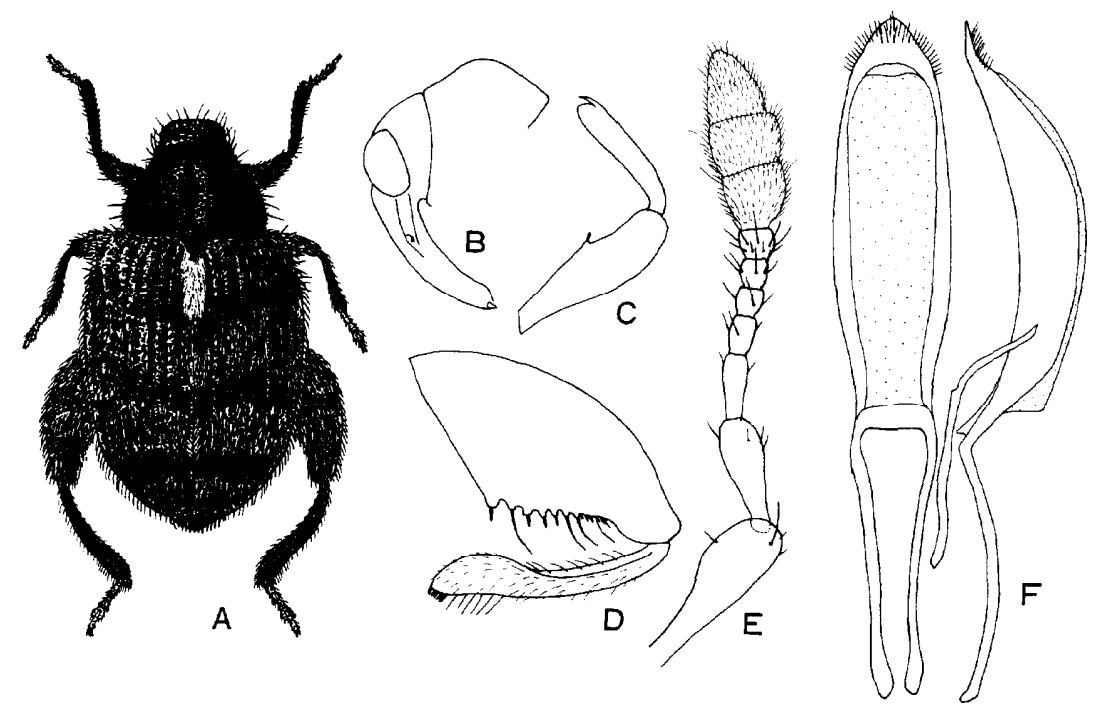

Fig. 44. Rhynchaenus (Orchestes) trifasciatus sp. nov. A : Male. B : Male head. C : Fore leg. D: Hind leg. E : Antenna. F : Penis. 
Fore coxal cavities linearly distant. Prosternum before coxae with a pair of weak carinae. Underside with dense punctures and coriaceous, fifth ventrite rugulose. Fore and mid femora armed with spine. Hind femora 2.1 times as long as wide, with seven to eight denticles, four to five long setae, four to five long spines, and fifteen to twenty short spines along hind margin.

Length : 3.2-3.5 mm.

Holotype male (Type No.2466, Kyushu Univ.), Tatsudayama, Kumamoto City, 13. vi. 1977, K. Morimoto leg.

Paratypes : Same locality as holotype, four males and thirteen females, 12. v-l. vii. 1977, K. Morimoto leg. Mt. Aoidake, Miyazaki Pref., one male, 24. vii. 1953, T. Yoshida leg. Obama, Nagasaki Pref., one female, 25. ii. 1960, T. Hidaka leg. Asakura, Fukuoka Pref., one female, 3. v. 1960, N. Gyotoku leg.

Distribution : Japan (Kyushu).

Biology : The adults were found on the leaves of Castanea crenata and Quercus sp. Many specimens were captured by the Malaise trap set in the campus of the Kyushu Branch Station, Forest Research Institute, Tatsudayama, Kumamoto. One female was collected by sifting the moss in winter. The teneral adults were found in May 23.

This new species is easily recognized by the conspicuous yellowish postscutellar patch and three greyish bands on elytra.

\section{References}

Bedel, L., $\quad$ 1888. Fame des Coléoptères du Bassin de la Seine. VI : Rhynchophora. 442 pp., 1 pl. Blatchley, W. S., and C. W. Leng, 1916. Rhynchophora or Weevils of North Eastern America.682pp. (Indianapolis).

Brisout de Barneville, H., 1865. Monographie des espèces européennes et algeriénnes du genre Orchestes. Ann. Soc. Ent. Fr., (4)V: 253-296.

Csiki, E., 1936. Coleopterorm Catalogus, 149, Cossoninae : 105-211.

Dieckmann, L., 1958. Die mitteleuropäischen Arten der Untergattung Pseudorchestes Bed. aus der Gattung Rhynchaenus Clairv. Ent. Blätt., $54: 5-25$.

1970. Zur Nomenklatur einiger europäischer Rüsselkäfer-Gattungen. Beitr. Ent., 20 : 111-128.

Dietz, W. G., 1891. Revision of the genera and species of Anthonomini inhabiting North America. Trans. Amer. Ent. Soc., 18: 177-276.

Egorov, A. B., 1977. A short review of weevils of Amur region and Khabarovsk Province. in Skariato, A. P., O. L. Kryzhanovskii and A. K. Galkin (eds.), Systematics and faunistics of Insects : 27-41. (Akademia Nauka SSSR, 114 pp., in Russian)

Faust, J., 1882. Rüsselkäfer aus dem Amurgebiet. Deut. Ent. Zeit., XXVI : 259-295.

1887. Curculionidenaus dem Amur-Gebiet. Deut. Ent. Zeit., XXXI : 161-180.

1894. Viaggio di Leonardo Fea in Birmania e regioni vicine, LX : Curculionidae. Ann. Mus. Civ. Stor. Nat. Genova, (2) XIV (XXXIV) : 153-370.

Gemminger, M. and E. Harold, 1871. Catalogus Coleopteronum. VIII :2180-2668.

Hatch, M. H., 1971. The Beetles of the Pacific Northwest. V: Rhipiceroide, Sternoxi, Phytophaga, Rhynchophora, and Lamellicornia. Univ. Washington Publ. Biol., 16 :xiv $+662 p p$.

Hayashi, N., 1959, Curculionidae. in Esaki et al., Illustrated Insect Larvae of Japan. $712+73+50$ pp., 712 figs. (Hokuryukan, Tokyo). (in Japanese)

Hoffmann, A., 1958. Faune de France, 62, Coléoptères Curculionides (3e) : 1209-1839. (Paul Lechevalier, Paris). 
Hustache, M. A., 1920. Contribution à la faune entomologique du Japon, Coléoptères Curculionides (2e). Bull. Mus. Nat. Hist. Nat. Paris, $1920: 630-637$.

- 1925. Curculionides nouveaux des Philippines et l'Orient. Philip. J. Sci., XXVII : 371-396.

Ichihashi, H., 1956. On two species of weevils from Mie Pref. Shin Konchu, 9(3): 47. (in Japanese) - 1961. Insects of Mt. Fujiwaradake, Mie. 88pp. (in Japanese)

Iga, M., 1955. Coloured Illustration of the Insects of Japan, Coleoptera. 196 pp., 64 col. pls. ; do, revised and enlarged edition, 230 pp., 68 col. pls. (Hoikusha, Osaka). (in Japanese)

Imasaka, S., A. Miyata and K. Hisakawa, 1980. On some Coleoptera captured in 1979. Niho no Mushi, (5) : l-54. (in Japanese)

Kaminaga, S., Y. Kishi and H. Kondo, 1973. On the biology and control of Rhynchaenus sanguinipes injurious to Zelkova serrata. Shinrin Boeki, 22(4):104-106. (in Japanese)

Klima, A., 1936. Coleopterorum Catalogus, 145, Rhynchaeninae. 36 pp.

-... 1936. Coleopterorum Catalogus, 146, Tachygoninae. 4 pp.

Kobayashi, F., 1977. Pests of the Garden Trees, II : 290 pp. (Nichirinkyo, Tokyo ; in Japanese)

Kôno, H., 1930. Langrtissler aus dem japanischen Reich. Ins. Mats., V: 1-31.

1935. Die Curculioniden aus den Kurilen, II. Ibid., $X: 1-31$.

1937. Die von H. Hori auf der Ins. Meshima gesammelten Curculioniden. Ibid., XI :129-130

1937. Neue und wenig bekannte Käfer Japans. III. Gattung Ixalma. Trans. Sapporo Nat. Hist. Soc., XV: 29-32.

1950. Curculionidae. in Esaki et al. Iconographia Insectorum Japonicorum. 1738 pp., 4967 figs. (Hokuryukan, Tokyo ; in Japanese)

Korotyaev, B. A., 1976. Review of weevils (Coleoptera, Curculionidae) of the Kamchatka Peninsula. Trudy Zool. Inst., LXII : 43-52.(in Russian)

1976. New species of weevils (Coleoptera, Curculionidae) from Wrangel Island. Ibid., LXX : 61-64.(in Russian)

Krivolutskaya, L. O., M. E. Ter-Minassian and A. B. Egorov., 1978. Curculionid fauna of the Kuril Islands and Saghalien. New materials on Insects from Saghalien and the Kuril Islands. Trudy Biologo-Potschvenno Instituta, (n. s.), 50 (153) : 85-101. (in Russian)

Kuroko, H., 1957. On the records of two'species belonging to the Tachygoninae. Konty $\hat{u}, 25: 109$. (in Japanese)

Kuwayama, S., 1967. Insect Fauna of the Southern Kurile Islands. 225 pp., 6 pls. (Hokunokai, Sapporo).

Lacordaire, M. T., 1863, 1866. Histoire Naturelle des Insectes, Genera des Coléoptères, VI, 637 pp ; VII, $620 \mathrm{pp}$.

LeConte, J. L. and G. H. Horn, 1876. The Rhynchophora of America North of Mexico. Proc. Amer. Phil. Soc., XV : xvi $+455 \mathrm{pp}$.

Marshall, G. A. K., 1915. Some injurious Indian weevils. Bull. Ent. Res., V : 377-380.

1935. New injurious Curculionidae from Malaya, Ibid., $26:$ 565-569.

1951. On a new Japanese Rhynchaenus. Mushi, $22: 87-88$.

1953. New Curculionidae from Indo-China. Ent. Month. Mag., lxxxix : 90-93.

1957. Some new Indonesian Curculionidae.Tijdschr. Ent., $100:$ 61-65.

Morimoto, K., 1953. On the biology of some Coleoptera. Gensei, II : 44 (in Japanese)

- 1955. Records of Ixalma dentipes in Kyushu. Shin Konchu, 8(3); 46 (in Japanese)

1955. Record of Rhynchaenus horii from Is. Okinoshina, Kochi. Gensei, IV : 5. (in Japanese)

1958. On some Curculionidae new to the fauna of Japan, (2). Kontŷu, 26:186. (in Japanese)

1960. Revision of the genus Ixalma Pascoe from Japan. Ins. Mats., $23: 46-51$.

- 1962. Key to families, subfamilies, tribes and genera of the superfamily Curculionoidea of Japan excluding Scolytidae, Platypodidae and Cossoninae. J. Fac. Agr., Kyushu Univ., 12 : 21-66. 1962. Provisional check list of the family Curculionidae of Japan. I. Sci. Bull. Fac.Agr., Kyushu Univ., 19: 183-217.

1964. Key and illustrations for the identification of the Curculionoid-beetles of Japan and

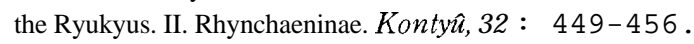


1984. Curculionidae. in Hayashi, M., Morimoto, K. and Kimoto, S. Coleoptera of Japan in Color. IV. 438pp., 72 col. pls. (Hoikusha, Osaka ; in Japanese)

Nakane, T., 1963. Curculionidae. in Nakane et al. Iconographia Insectorum Japonicorum Colore Naturali Edita, II, 443 pp., 192 col. pls. (Hokuryukan, Tokyo ; in Japanese)

Nishitani, J., 1920. On the apple flea weeils. Ins. World, Gifu., XXIV (273) : 164-167. (in Japanese) 1930. On the distribution of Rhamphus pulicarium. Aomori Nokaiho, (209) : 14-17. (in Japanese)

Obara, A., 1957. On the outbreak of Rhynchaenus sanguinipes in Fukui. Shinrin Boeki News., 6(11): 242-243. (in Japanese)

Ohno, M., 1954. On three species of the genus Ixalma. Shin Konchu, 7(13):27. (in Japanese)

- 1957. On Togezo takahashii. Ibid., 10(1): 46. (in Japanese)

Oishi, T., 1927. Studies on the insects injurious to cherry. III. Byochugai Zasshi., XIV : 684-696. (in Japanese)

Pascoe, F. P., 1860. Notices of new or little-known genera and species of Coleoptera. Journ. Ent., I : 36-64, 2 pls.

- 1871. Contributions towards a knowledge of the Curculionidae. II Journ. Linn. Soc., Zool., $X I: 154-218$, 4pls.

1873. Ditto IV. Ibid., XII : 1-99, 4pls.

Pomorski, R. J., 1978. Das Vorkommen des Maulikschen Sprungapparates bei den Springrtisslern. Polsk. Pism. Ent., 43: 601-602.

Reitter, E., 1911. Uebersicht der Arten des Rüsselkäfer Gattung Rhynchaenus Clairv. (Orchestes Ill.) aus der Verwandtschaft des Rh. pratensis Germ. Wien. Ent. Zeit., XXX : 279-282.

1916. Fauna Germanica. Die Käfer des Deutschen Reiches. V. 343 pp., Taf. 153-168.

Roelofs, W., 1874, 75. Curculionides recueillis au Japon par M. G. Lewis, Ann. Soc. Ent. Belg., XVII : 121-176 ; XVIII : 149-193, 3 pls.

1879. Diagnoses de nouvelles espèces de Curculionides, Brenthides, Anthribides et Bruchides du Japon. Ibid., XXII, Compt. rend. : liii-lv.

1880. Addition à la faune de Japon. Ann. Soc. Ent. Belg., XXIV: 5-31.

Schenkling, S., 1907. Unsere Orchestes-Arten. Ent. Wochenblatt, XXIV :7-10.

Schoenherr, C. J., 1826. Curculionidum Dispositio Methodica. 338pp.

- 1843. Genera et Species Curculionidum. VII(2).502pp.

Smreczynski, S., 1960. Bemerkungen über die heimischen Rüsselkäfer. IV. Acta Zool. Cracov., V : 4586.

Takahashi, S., 1930. Kaju Gaichu Kakuron, I. 580 pp. (Meibundo, Tokyo). (in Japanese)

Ter-Minassian, M. E., 1953. Revision of the genus Rhynchaenus Clairv. (=Orchestes Ill.) of USSR. Ent. Oboz., XXXIII : 311-324. (in Russian)

Thomson, C. G., 1859. Skandinaviens Coleoptera, I. 290pp.

Viramo, J., 1965. Ueber die Arten der Gattung Rhamphus Clairv. in Finnland. Ann. Ent. Fenn., 31 : 88-94.

Voss, E., 1936 Ueber die Tribus Scolopterini sowie einige verwandte Gattungen und Gruppen von Neu-Zeeland. Arb. morph. tax. Ent. Dahlem., 3: 60-62, 110-121.

1941. Bemerkenswerte und unbeschriebene Rüsselkäferaus China und Japan. Mitt. Münch. Ent. Ges., $31: 887-902$.

1949. Ueber einige in Fukien gesammelte Rüssler. III. Ent. Blätt., 41-44 : 153-164 ; IV. Ibid., 49 : $42-82$.

1952. Mandschurische Rüssler aus dem Museum G. Frey. Mitt. Münch. Ent. Ges., XLII : 190205.

1956. Ueber einige japanische Rüsselkäfer. Akitu, V :13-16.

1957. Neue und bekannte, vorwiegend indonesische Curculioniden. Treubia, 24 : 7-63.

1958. Ein Beitrag zur Kenntnis der Curculioniden in Grenzgebiet der Orientalischen zur Palaarktischen Region. Decheniana, Beihefte 5, 139 pp.

1959. Afghanistans Curculionidenfauna, nach den jüngsten Forschungsergebnissen zusam- 
mengestellt. Ent. Blätt., 55: 65-162.

1962. Ergebnisse der Zoologischen Nubien-Expedition 1962. Teil XXII. Coleoptera :Curculionidae. Ann. Natwhist. Mus. Wien, 67 : 583-601.

Winkler, W., 1932. Catalogus Coleopterorum Regionis Palaearcticae. 1698pp.

Yokomizo, Y., 1976. On some injurious insects to Betula platyphylla var. japonica at the nursery in Tochigi Pref. Shinrin Boeki, 25(7) : 4-8. (in Japanese) 